(a)

Modeling Ice Passage Through

a Submergible and Non-submergible Tainter Gates

Gordon Gooch, John Rand, Ben Hanamoto and Jon Zufelt November 1990 
This report is printed on paper that contains a minimum of $50 \%$ recycled material. 


\section{Special Report 90-39}

U.S. Army Corps of Engineers

Cold Regions Research \& Engineering Laboratory

\section{Modeling Ice Passage Through Submergible and Non-submergible Tainter Gates}

Gordon Gooch, John Rand, Ben Hanamoto and John Zufelt 


\section{PREFACE}

This report was prepared by Gordon Gooch, Civil Engineering Technician, John Rand, Research General Engineer, Ben Hanamoto, Research General Engineer, and Jon Zufelt, Research Hydraulic Engineer, all of the Ice Engineering Research Branch, Experimental Engineering Division, U.S. Army Cold Regions Research and Engineering Laboratory. Funding for this research was provided by the U.S. Army Engineer District, Rock Island.

Dr. Jean-Claude Tatinclaux and Dr. James Lever technically reviewed the manuscript of this report.

The contents of this report are not to be used for advertising or promotional purposes. Citation of brand names does not constitute an official endorsement or approval of the use of such commercial products. 


\section{CONVERSION FACTORS: U.S.CUSTOMARY TO METRIC (SI) UNITS OF MEASUREMENT}

These conversion factors include all the significant digits given in the conversion tables in the ASTM Metric Practice Guide (E 380), which has been approved for use by the Department of Defense. Converted values should be rounded to have the same precision as the original (see E 380).

\begin{tabular}{lll}
\multicolumn{1}{c}{ Multiply } & \multicolumn{1}{c}{ By } & Toobtain \\
\hline inch & 25.4 & millimeter \\
foot & 0.3048 & meter \\
foot ${ }^{3} /$ second & 0.02831685 & meter $^{3} /$ second \\
gallon/minute & 0.00006309020 & meter $3 /$ second \\
degrees Fahrenheit & $t^{\circ} \mathrm{C}=\left(t^{\circ} \mathrm{F}-32\right) / 1.8$ & degrees Celsius \\
& & \\
\hline
\end{tabular}




\title{
Modeling Ice Passage Through Submergible and Non-submergible Tainter Gates
}

\author{
GORDON GOOCH, JOHN RAND, \\ BEN HANAMOTO AND JON ZUFELT
}

\section{INTRODUCTION}

This study examined ice passage through two types of tainter gates using CRREL's Starved Rock Lock and Dam model (Fig. 1). Our objectives were to model the flow of ice through the existing tainter gates and through submergible tainter gates in the same location (Fig. 2), to move the submergible gates to a location closer to the lock chamber and model the ice passage at that new location, and finally to compare, when possible, plastic ice and real ice and to observe the effect of each.

All tests simulated typical low flow conditions of approximately $6000 \mathrm{ft}^{3} / \mathrm{s}$ with normal winter ice conditions of 6 to $18 \mathrm{in}$. of brash ice in the ship track. Near-surface water velocities were obtained with each gate setting to evaluate any changes in the flow pattern and velocity.

Each test was documented by still photographs and 1/2-in. VHS video. A summary of the video is available from CRREL. Reference photographs are included here as Appendix A.

Throughout this report, submergible tainter gates will be called just that, while the normal tainter gates will be simply tainter gates.

\section{SCALE MODEL HYDRAULIC DESIGN}

The Starved Rock Lock and Dam physical model, built in the refrigerated research area of CRREL's Ice Engineering Facility, is an undistorted Froude model, constructed at a length scale ratio of 25:1.

Ice conveyance and transport can be studied as a two-dimensional process in either an undistorted or distorted model. The passage of ice over and under gates, however, is inherently a three-dimensional process. To maintain model similarity near the gate structures, it was necessary to ensure that the vertical and horizontal scales be equal and thus we used an undistorted model.

In a Froude model, the Froude number of the model and the full-scale structure must be equal.

$$
(F r)_{\mathrm{r}}=\frac{(F r)_{\mathrm{p}}}{(F r)_{\mathrm{m}}}=\frac{V_{\mathrm{r}}}{\sqrt{g_{\mathrm{r}}{ }_{\mathrm{r}}}}=1
$$

where

$\mathrm{Fr}=$ Froude number

$V=$ velocity

$g=$ acceleration due to gravity

$h=$ depth

$V_{\mathrm{r}}=$ velocity ratio $=V_{\mathrm{p}} / V_{\mathrm{m}}$

$r=$ ratio full scale/model scale

$p=$ prototype (full scale)

$m=$ model.

The scale of a model is often represented by means of its length ratio $L_{\mathrm{r}}$, which is equal to the characteristic horizontal length ratio $L_{\mathrm{p}} / L_{\mathrm{m}}$, the flow depth ratio $h_{\mathrm{r}}=h_{\mathrm{p}} / h_{\mathrm{m}}$, discharge $Q$ and area of cross section $A$. Since the acceleration due to gravity is the same in the model and in the prototype, $g_{\mathrm{r}}$ (the gravity ratio) $=g_{\mathrm{p}} / g_{\mathrm{m}}=1$, and since $h_{\mathrm{r}}=L_{\mathrm{r}}$ in an undistorted model, we see that $V_{\mathrm{r}}=$ $\left(L_{\mathrm{r}}\right)^{1 / 2}$. Since $Q_{\mathrm{r}}=A_{\mathrm{r}} V_{\mathrm{r}}$ and $A_{\mathrm{r}}=L_{\mathrm{r}}$, then $Q_{\mathrm{r}}=$ $L_{\mathrm{r}}^{5 / 2}$.

The mean winter discharge at Starved Rock Lock and Dam is approximately $6300 \mathrm{ft}^{3} / \mathrm{s}$, with a minimum shipping channel depth of $12 \mathrm{ft}$. The maximum scale for a model (large model) is dependent on the space and pumping capacity available and the minimum scale (small model) is dependent on measurement accuracy and the requirement to avoid viscous and surface tension scale effects. Based on these requirements, a length scale ratio of 25:1 was chosen, which resulted in a mean winter model discharge of approximately $900 \mathrm{gal} . / \mathrm{min}$ (about mid-range of the facility's 


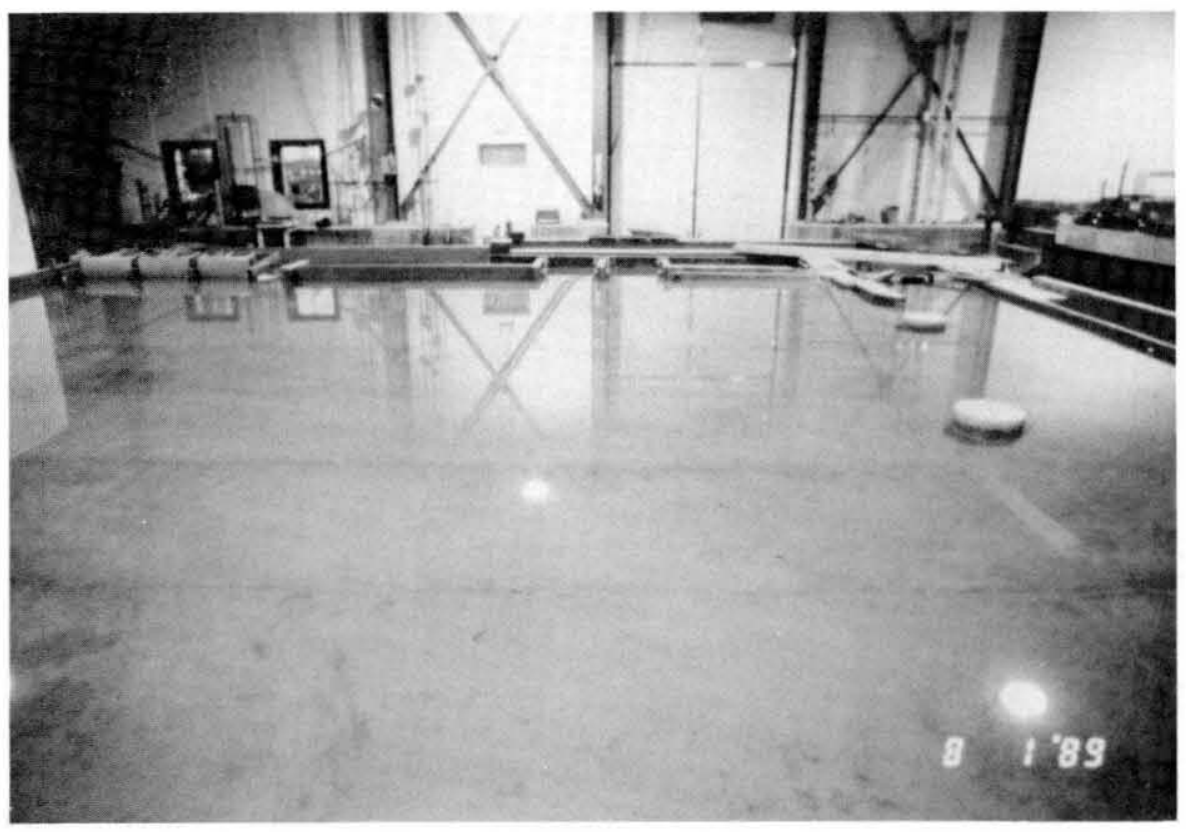

Figure 1. Starved Rock Lock and Dam model. Lock approach on right; submergible gates at site 2 in center; existing tainter gates, site 1, on left.

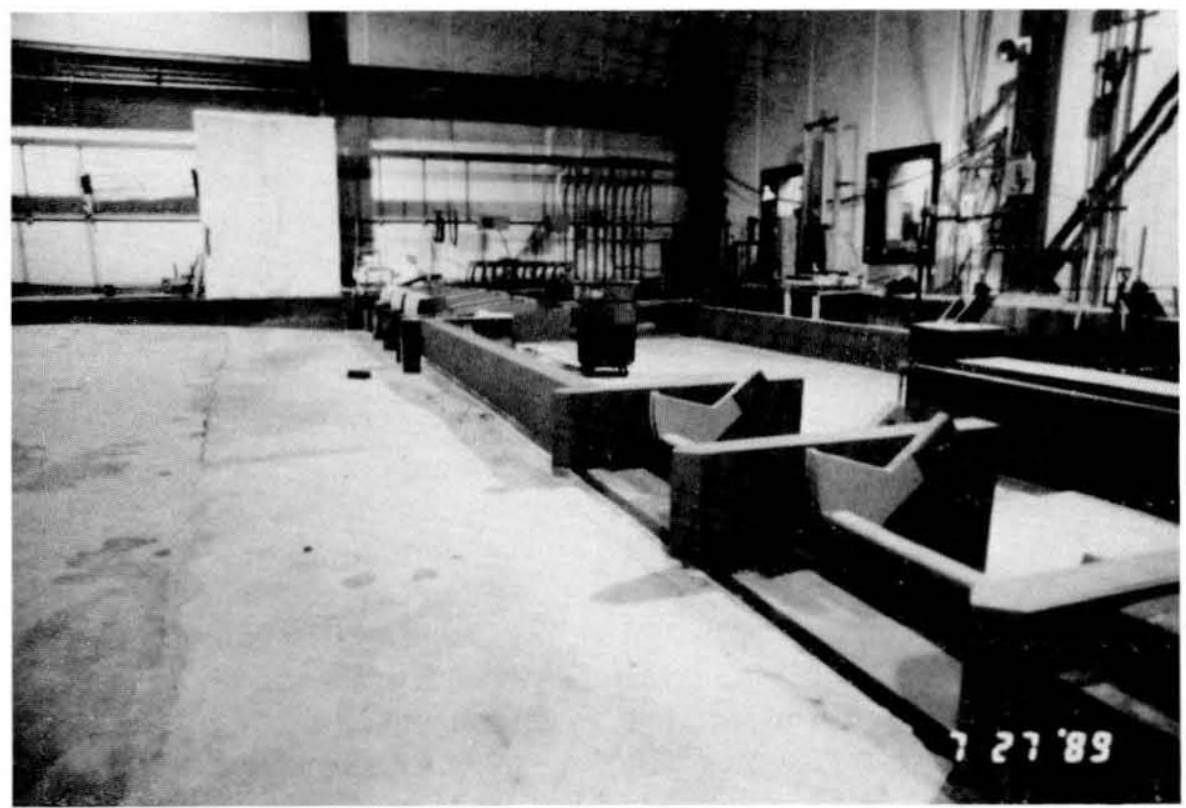

Figure 2. Model submergible gates. 
pumping capacity). With this model scale, the model depths would range from $0.1 \mathrm{ft}$ (over submerged Leopold Island) upstream of the dam to approximately $1.0 \mathrm{ft}$ in the deepest sections, which are suitable to retain measurement accuracy.

At this scale, though, a model covering the full river width would be too large to fit in the refrigerated research area. However, during the winter months, when ice passage is a problem at Starved Rock Lock and Dam, only the first one or two tainter gates are operated, with an average total opening of about $4.0 \mathrm{ft}$. The entire river freezes over except for the continually rebroken shipping lane hugging the right bank. The areas of interest when the river is ice covered are the shipping channel and the portion of the river extending over to the first two tainter gates of the dam. Submerged Leopold Island also forms somewhat of a separation line down the center of the river. Based on this information, we decided to build the model for only a portion of the river and to calibrate the model to the mean winter discharge, velocities and ice conditions.

The model is $40 \mathrm{ft}$ wide by $130 \mathrm{ft}$ long, which is a full-scale size of 1000 by $3250 \mathrm{ft}$ (Fig. 3). It includes the lock approach guide wall, the upper miter gates and three of the ten tainter gates on the dam. Since only the first two tainter gates are operated during the winter (ice problem periods), no adjustments were necessary to the model discharge. The use of a partial model, however, reduced the flow area and made it possible that the

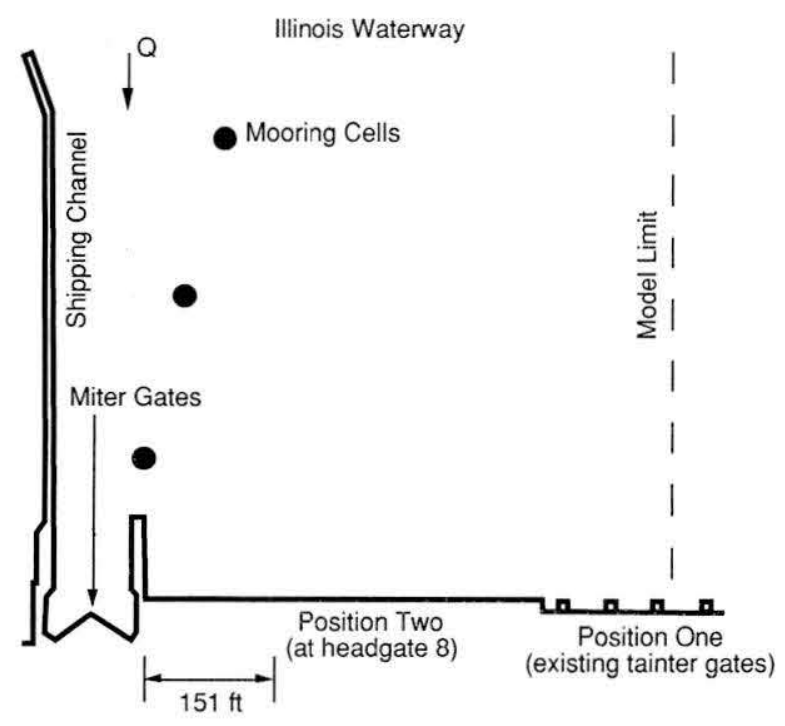

Figure 3. Model limits.
Table 1. Tainter gate openings for January and February 1989.

\begin{tabular}{|c|c|c|c|}
\hline January & $\begin{array}{c}\text { Avernge } \\
\text { 24-hour } \\
\text { total } \\
\text { gate opening } \\
\text { (ft) }\end{array}$ & February & $\begin{array}{c}\text { Average } \\
24-\text { hour } \\
\text { total } \\
\text { gate opening } \\
(f t)\end{array}$ \\
\hline 1 & 8.0 & 1 & 6.8 \\
\hline 2 & 7.0 & 2 & 6.2 \\
\hline 3 & 6.6 & 3 & 6.6 \\
\hline 4 & 5.7 & 4 & 5.3 \\
\hline 5 & 6.2 & 5 & 4.3 \\
\hline 6 & 7.6 & 6 & 3.7 \\
\hline 7 & $8 . .2$ & 7 & 4.3 \\
\hline 8 & 12.6 & 8 & 4.6 \\
\hline 9 & 13.6 & 9 & 4.5 \\
\hline 10 & 11.9 & 10 & 3.9 \\
\hline 11 & 12.1 & 11 & 4.0 \\
\hline 12 & 10.3 & 12 & 4.6 \\
\hline 13 & 9.1 & 13 & 3.6 \\
\hline 14 & 8.3 & 14 & 4.2 \\
\hline 15 & 7.3 & 15 & 5.0 \\
\hline 16 & 7.1 & 16 & 4.7 \\
\hline 17 & 6.9 & 17 & 5.5 \\
\hline 18 & 6.2 & 18 & 4.2 \\
\hline 19 & 6.2 & 19 & 4.8 \\
\hline 20 & 6.0 & 20 & 4.6 \\
\hline 21 & 5.7 & 21 & 4.4 \\
\hline 22 & 5.3 & 22 & 4.4 \\
\hline 23 & 5.3 & 23 & 4.2 \\
\hline 24 & 5.1 & 24 & 4.1 \\
\hline 25 & 5.5 & 25 & 4.2 \\
\hline 26 & 6.0 & 26 & 4.0 \\
\hline 27 & 6.2 & 27 & 4.3 \\
\hline 28 & 5.9 & 28 & 3.7 \\
\hline 29 & 6.7 & Average & 4.5 \\
\hline 30 & 6.5 & & \\
\hline 31 & 7.3 & & \\
\hline Average & 7.2 & & \\
\hline
\end{tabular}

model velocities could be too high and thus not be representative of full-scale conditions. A detailed field survey of two-dimensional water velocities was conducted to calibrate the model velocities. We used flow dividers, aligners and roughness elements to adjust the model velocities to match the full-scale measurements (at $V_{\mathrm{r}}=5$ ).

The entire series of tests was based on the typical winter-time hydraulic conditions experienced at Starved Rock. Monthly flow records were provided by the lockmaster and are shown in Appendix B. From these data, we found that the average 24-hour gate opening for Starved Rock for the month of February 1989 was $4.5 \mathrm{ft}$. The record of the various daily settings is provided in Table 1. According to the USGS stage-discharge rating 
Table 2. USGS stage-discharge curve for Starved Rock Dam. After USGS (1981) Stage discharge relationships at dams on the Illinois and Des Plaines rivers in Illinois. U.S. Geological Survey Report 81-1009.

\begin{tabular}{|c|c|c|c|c|c|c|c|c|c|}
\hline \multirow{2}{*}{$\begin{array}{c}\text { Gate } \\
\text { opening } \\
(f t)\end{array}$} & \multicolumn{9}{|c|}{ Discharge $\left(f t^{3} / s\right)$ for downstream pool elevations of: } \\
\hline & 442 & 444 & 446 & 448 & 450 & 452 & 454 & 456 & $458^{*}$ \\
\hline 0.0 & 0 & 0 & 0 & 0 & 0 & 0 & 0 & 0 & 0 \\
\hline 0.5 & 781 & 686 & 594 & 521 & 454 & 387 & 315 & 231 & 102 \\
\hline 1.0 & 1,560 & 1,490 & 1,290 & 1,130 & 987 & 841 & 686 & 502 & 221 \\
\hline 1.5 & 2,340 & 2,340 & 2,030 & 1,780 & 1,550 & 1,330 & 1,080 & 791 & 348 \\
\hline 2.0 & 3,110 & 3,110 & 2,820 & 2,470 & 2,150 & 1,830 & 1,490 & 1,090 & 481 \\
\hline 2.5 & 3,880 & 3,880 & 3,630 & 3,180 & 2,770 & 2,360 & 1,910 & 1,400 & 617 \\
\hline 3.0 & 4,620 & 4,620 & 4,460 & 3,910 & 3,400 & 2,900 & 2,360 & 1,720 & 757 \\
\hline 3.5 & 5,340 & 5,340 & 5,340 & 4,660 & 4,060 & 3,460 & 2,810 & 2,040 & 899 \\
\hline 4.0 & 6,020 & 6,020 & 6,020 & 5,430 & 4,730 & 4,030 & 3,280 & 2,400 & 1,040 \\
\hline 4.5 & 6,540 & 6,540 & 6,540 & 6,220 & 5,410 & 4,610 & 3,760 & 2,750 & 1,190 \\
\hline 5.0 & 7,210 & 7,210 & 7,210 & 7,030 & 6,120 & 5,210 & 4,240 & 3,100 & 1,340 \\
\hline 5.5 & 7,780 & 7,780 & 7,780 & 7,780 & 6,840 & 5,830 & 4,740 & 3,470 & 1,490 \\
\hline 6.0 & 8,320 & 8,320 & 8,320 & 8,320 & 7,590 & 6,460 & 5,260 & 3,840 & 1,640 \\
\hline 6.5 & 8,860 & 8,860 & 8,860 & 8,860 & 8,380 & 7,110 & 5,780 & 4,230 & 1,800 \\
\hline 7.0 & 9,380 & 9,380 & 9,380 & 9,380 & 9,170 & 7,800 & 6,320 & 4,620 & 1,950 \\
\hline 7.5 & 9,880 & 9,880 & 9,880 & 9,880 & 9,880 & 8,500 & 6,870 & 5,030 & 2,110 \\
\hline 8.0 & 10,400 & 10,400 & 10,400 & 10,400 & 10,400 & 9,220 & 7,490 & 5,440 & 2,390 \\
\hline 8.5 & 10,800 & 10,800 & 10,800 & 10,800 & 10,800 & 9,960 & 8,040 & 5,860 & 2,580 \\
\hline 9.0 & 11,300 & 11,300 & 11,300 & 11,300 & 11,300 & 10,700 & 8,710 & 6,360 & 2,770 \\
\hline 9.5 & 11,800 & 11,800 & 11,800 & 11,800 & 11,800 & 11,500 & 9,360 & 6,830 & 2,970 \\
\hline 10.0 & 12,200 & 12,200 & 12,200 & 12,200 & 12,200 & 12,200 & 10,000 & 7,320 & 3,170 \\
\hline 10.5 & 12,700 & 12,700 & 12,700 & 12,700 & 12,700 & 12,700 & 10,700 & 7,820 & 3,380 \\
\hline 11.0 & 13,100 & 13,100 & 13,100 & 13,100 & 13,100 & 13,100 & 11,500 & 8,350 & 3,590 \\
\hline 11.5 & 13,500 & 13,500 & 13,500 & 13,500 & 13,500 & 13,500 & 12,300 & 8,900 & 3,810 \\
\hline 12.0 & 13,900 & 13,900 & 13,900 & 13,900 & 13,900 & 13,900 & 13,100 & 9,550 & 4,030 \\
\hline 12.5 & 14,300 & 14,300 & 14,300 & 14,300 & 14,300 & 14,300 & 14,300 & 10,200 & 4,260 \\
\hline 13.0 & 14,500 & 14,500 & 14,500 & 14,500 & 14,500 & 14,500 & & submerged weir & \\
\hline 13.5 & 14,500 & 14,500 & 14,500 & 14,500 & 14,500 & & & flow & \\
\hline
\end{tabular}

* Feet above mean sea level.

curve for a tainter gate at Starved Rock (Table 2), a discharge rate of 6020 to $6540 \mathrm{ft}^{3} / \mathrm{s}$ corresponds to a gate setting between 4 and $4.5 \mathrm{ft}$ and a downstream pool elevation of $446 \mathrm{ft}$ above mean sea level.

Information obtained from the daily navigation report and from personal conversations with the Lockmaster disclosed that the ice that typically forms in the ship tracks is broken floating ice about 6 to 18 in. thick.

\section{GATE HYDRAULICS}

We assessed the hydraulics and ice passage capabilities of two types of gates during this model study: standard tainter gates and submergible gates. The hydraulics of the two gate types are quite different, with the tainter operating in a pressure flow situation while the submergible operates in the gravity-free overfall condition.
Consequently, the heads across the gates and their effects on the discharge are also quite different. The tainter is raised to allow flow to pass beneath it, resulting in a high head (the difference between the water surface elevations above and below the gate), forcing flow through an orifice beneath the gate. Discharge is generally given by a formula relating orifice area and the head across the gate

$$
Q_{\mathrm{t}}=C_{\mathrm{t}} A_{\mathrm{g}}(2 g H)^{1 / 2}
$$

where

$$
\begin{aligned}
Q_{\mathrm{t}}= & \text { discharge under the tainter gate } \\
C_{\mathrm{t}}= & \text { dischargecoefficient for a taintergate } \\
A_{\mathrm{g}}= & \text { area of the gate opening } \\
H= & \text { head across the gate, i.e., the differ- } \\
& \text { ence in water surface elevations be- } \\
& \text { tween the upstream and down- } \\
& \text { stream pools. } \\
g= & \text { acceleration due to gravity. }
\end{aligned}
$$


For the tainter gates at Starved Rock, the discharge coefficient $C_{t}$ was 0.78 for winter conditions and the area of the gate opening $A_{\mathrm{g}}$ is the width of the gate $(60 \mathrm{ft})$ times the gate lift. Thus, for a tainter gate, the discharge varies with the head to the $1 / 2$ power. Experience at Starved Rock has shown that a tainter gate must be raised at least $4 \mathrm{ft}$ before ice will begin to be drawn under the gate and passed downstream. At this opening, however, ice passage is slow and ice bridges typically form at the gate opening, requiring repeated assistance from tow boats to break them up.

A submergible gate is operated by lowering the gate below the water surface and allowing flow to pass over its crest. This type of gate is similar to an ogee crest overfall spillway and thus the head is measured as the difference between the water surface elevation upstream and the top of the submerged gate. Discharge is generally given by a formula relating this head, gate width and a discharge coefficient

where

$$
Q_{\mathrm{s}}=C_{\mathrm{s}} B H^{3 / 2}
$$

$$
\begin{aligned}
Q_{\mathrm{S}}= & \text { discharge over the submergiblegate } \\
C_{\mathrm{S}}= & \text { discharge coefficient for the sub- } \\
& \text { mergible gate } \\
B= & \text { gate width } \\
H= & \text { head on the gate or gate opening. }
\end{aligned}
$$

For the model, the discharge coefficient $C_{\mathrm{s}}$ was found to be about 3.4 for the range of winter flows associated with ice passage problems. The submergible gates were slightly narrower than the tainter gates ( $52 \mathrm{ft}$, full-scale) because of the gate lowering mechanism. Therefore, the discharge for a submergible gate varies with the head to the $3 / 2$ power.

What we see from these formulae for the discharge through the two types of gates is that, for a given discharge, the submergible gate must have a greater opening. This is beneficial in times of low flow when ice passage is difficult. For example, for the mean winter discharge of $6300 \mathrm{ft}^{3} / \mathrm{s}$, one tainter gate must be raised $4.1 \mathrm{ft}$. At this opening, the tainter will pass ice. For the same discharge, a submergible gate of the same width must be, or more aptly expressed, can be lowered $9.7 \mathrm{ft}$. Similarly, one could lower two submergible gates $6.1 \mathrm{ft}$ each to accommodate the same flow. With submergible gates, ice passage is not a problem at these openings. Experience at other facilities with submergible gates has shown adequate ice passage at gate openings of $3 \mathrm{ft}$ (which would corre-

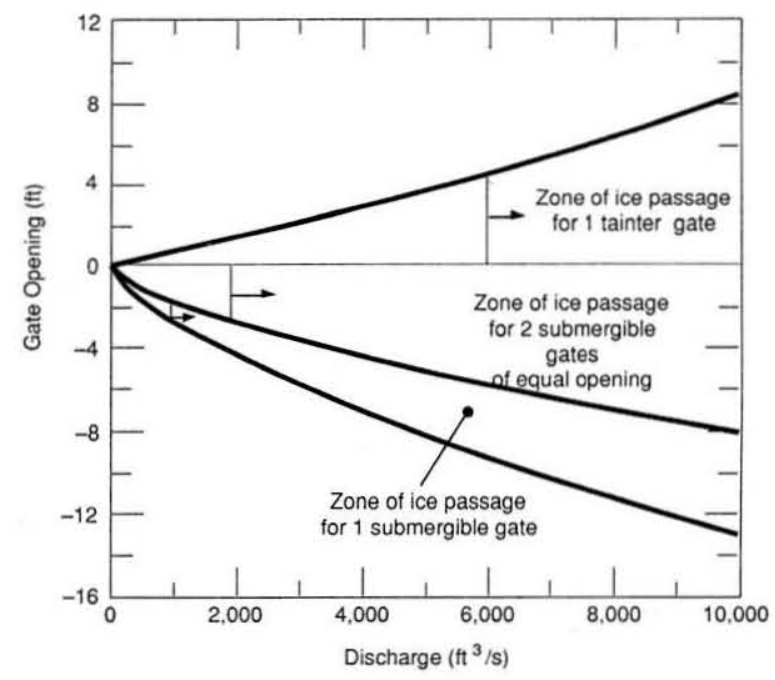

Figure 4. Plot of gateopening vs dischargeand the zones of ice passage.

spond to a discharge of about $1100 \mathrm{ft}^{3} / \mathrm{s}$ for a 60 -ftwide gate). Figure 4 is a plot of gate openings vs discharge for the two types of gates. The zones of ice passage are also marked for each type of gate. The most appropriate position of submergiblegates at Starved Rock Lock and Dam, as well as the probability of ice bridging, are discussed later.

\section{MODEL CALIBRATION}

The Starved Rock model was calibrated by matching the model water surface elevation and velocities to the measured full-scale elevation and velocities at a full-scale mean winter discharge of $6300 \mathrm{ft}^{3} / \mathrm{s}$. As stated above, for an undistorted Froude model, the discharge scale ratio is $Q_{\mathrm{r}}=$ $L_{\mathrm{r}} 5 / 2$ or for the Starved Rock Lock and Dam model $(25)^{5 / 2}=3125$. Since $Q_{\mathrm{r}}=Q_{\mathrm{p}} / Q_{\mathrm{m}}$, for a full-scale discharge of $6300 \mathrm{ft}^{3} / \mathrm{s}$

$$
3125=\frac{6300 \mathrm{ft}^{3} / \mathrm{s}}{Q_{\mathrm{m}}}
$$

or

$$
\begin{aligned}
Q_{\mathrm{m}}= & 2.01 \mathrm{ft}^{3} / \mathrm{s} \times 449(\mathrm{gal} . / \mathrm{min}) /\left(\mathrm{ft}^{3} / \mathrm{s}\right)= \\
& 902 \mathrm{gal} . / \mathrm{min}
\end{aligned}
$$

To be assured of standard conditions for the model flow calibration, we maintained runs of 900 gal./min and an upper pool elevation of 458.75 with a single tainter gate opening of $4 \mathrm{ft}$ (full scale). Similar tests with the submergible gates provided 
individual full-scale gate settings of $6.75 \mathrm{ft}$ for each of two submergible gates.

\section{TESTING SEQUENCE}

The test sequence is summarized in Table 3. As previously stated, the model flow conditions were $900 \mathrm{gal} . / \mathrm{min}\left(6300 \mathrm{ft}^{3} / \mathrm{s}\right.$ full scale) and for the last two tests we used a lower flow of $315 \mathrm{gal} . / \mathrm{min}$ $\left(1972 \mathrm{ft}^{3} / \mathrm{s}\right.$ full scale). The locations of the gates for the various tests are identified as position 1 and position 2. Position 1 is the location of the existing tainter gates at Starved Rock Lock and Dam. Position 2 is a new location, which is proposed as an alternate site for the construction of two new submergible tainter gates. The location of the position 2 is at headgate 8 , which is $151 \mathrm{ft}$ from the ramp up to the headgates (Fig. 3).

Another variable in the test sequence was the type of ice used. Our initial tests were conducted with 4 -in. squares of $1 / 4$-in.-thick low density polyethylene plastic ice. The scaled thickness of this ice was $0.5 \mathrm{ft}$. In addition, freshwater ice was used for a number of tests. Its scaled thickness ranged from 0.5 to $1.3 \mathrm{ft}$.

Test 1 is the open water calibration test in which a constant pool elevation of $458.75 \mathrm{ft}$ was maintained with a model flow of $900 \mathrm{gal} / \mathrm{min}$. In this test, gate openings that corresponded to full-scale settings for low flow, winter conditions were used for both the tainter gate and the submergible gates. The full-scale gate openings were $4 \mathrm{ft}$ for a single tainter gate or $6.75 \mathrm{ft}$ for each of two submergible gates. As a comparison to later tests, the water velocities near the surface were obtained with two tainter gates open to a 2 -ft depth each. Figure 5 shows the flow pattern that developed with this latter condition.

Test 2 was the first of three tests using the plastic ice with the tainter gates in position 1 . Two tainter gates were each opened $2 \mathrm{ft}$ (full scale). The plastic ice was placed in the model at mid-pool and allowed to float down to the dam. It was unable to pass under the tainter gates with the 2 -ft setting. It should be noted that experience at Starved Rock Lock and Dam shows that they are unable to pass ice with a single gate opening less than $4 \mathrm{ft}$.

Test 3 was our first test with the submergible gates. Plastic ice was pooled upstream of the dam. As expected, with the increased opening required for the submergible gates and the flow being over the gate, the ice quickly passed. This run was also used to calibrate the submergible gates. The total

Table 3. Test summary.

\begin{tabular}{|c|c|c|c|c|c|c|c|c|}
\hline Test & $\begin{array}{c}\mathrm{Q} \\
\text { (gal.) } \\
\min )\end{array}$ & Gate & Position & $\begin{array}{l}\text { Ice } \\
\text { type }\end{array}$ & $\begin{array}{c}\text { Total } \\
\text { gate } \\
\text { opening } \\
(f t)\end{array}$ & $\begin{array}{l}\text { Average } \\
\text { ice } \\
\text { thickness } \\
(f t)\end{array}$ & $\begin{array}{l}\text { Temp. } \\
\left({ }^{\circ} \mathrm{F}\right)\end{array}$ & $\begin{array}{l}\text { Date } \\
\text { (1989) }\end{array}$ \\
\hline 1 & 900 & Standard & 1 & None & $4^{*}$ & $\begin{array}{l}\text { open water } \\
\text { calibration }\end{array}$ & 50 & 27 June \\
\hline 2 & 900 & Standard & 1 & Plastic & $4^{*}$ & 0.5 & 50 & 28 June \\
\hline 3 & 900 & Submergible & 1 & Plastic & $11.6^{*}$ & 0.5 & 50 & 29 June \\
\hline 4 & 900 & Submergible & 1 & None & $13.5^{*}$ & $\begin{array}{l}\text { velocity } \\
\text { measurements }\end{array}$ & 50 & 6 July \\
\hline 5 & 900 & Submergible & 1 & Plastic & $13.5^{*}$ & $\begin{array}{l}0.5 \text {; boom } \\
\text { test }\end{array}$ & 50 & 8 July \\
\hline 6 & 900 & Submergible & 2 & Natural & $13.5^{*}$ & 0.6 & 25 & 3 Aug \\
\hline 7 & 900 & Submergible & 2 & Natural & $13.5^{*}$ & 1.3 & 25 & 4 Aug \\
\hline 8 & 900 & Submergible & 2 & Natural & $13.5^{*}$ & 1.2 & 25 & 7 Aug \\
\hline 9 & 900 & Submergible & 2 & Natural & $13.5^{*}$ & 1.2 & 15 & 8 Aug \\
\hline $10 \mathrm{~S}$ & 900 & Submergible & 2 & Natural & $13.5^{*}$ & 0.6 & 25 & 9 Aug \\
\hline $10 \mathrm{~T}$ & 900 & Standard & 1 & Natural & $4^{* *}$ & 0.6 & 25 & 9 Aug \\
\hline $11 \mathrm{~S}$ & 900 & Submergible & 2 & Natural & $13.5^{*}$ & 1.3 & 25 & 10 Aug \\
\hline $11 \mathrm{~T}$ & 900 & Standard & 1 & Natural & $4^{* *}$ & 1.3 & 25 & 10 Aug \\
\hline $12 \mathrm{~A}$ & 315 & Submergible & 2 & Natural & $6.75^{*}$ & 1.1 & 20 & 11 Aug \\
\hline $12 \mathrm{~B}$ & 315 & Submergible & 2 & Plastic & $6.75^{*}$ & 0.5 & 20 & 11 Aug \\
\hline
\end{tabular}

*Two gates

**One gate 


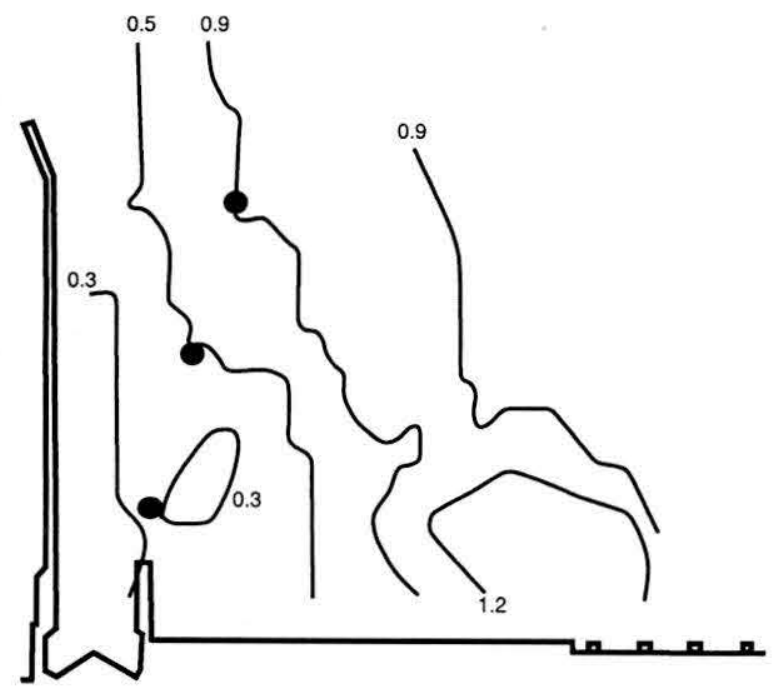

Figure 5. Velocity profile $(\mathrm{ft} / \mathrm{s})$ with two tainter gates open to a 2-ft depth (full scale).

gate setting needed to maintain the constant pool elevation was $13.5 \mathrm{ft}$ full scale $(6.75 \mathrm{ft} \times 2$ gates).

Test 4 was used to document the flow patterns around the two submergible gates with a total gate opening of $13.5 \mathrm{ft}$. The flow pattern developed in open water around the submergible gates in position 1 is shown in Figure 6.

Test 5 analyzed how the submergible gates in position 1 passed plastic ice with ice booms placed

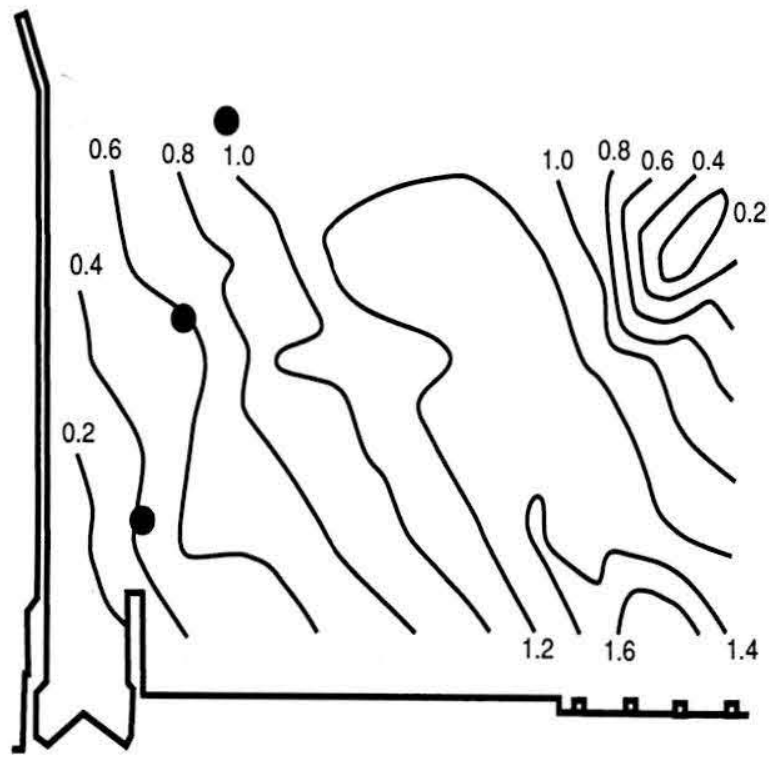

Figure 6. Velocity profile (ft/s) with two submergible gates, each with a 6.7-ft opening (full scale) in position 1. so that they extended from the gates to the area between the second and third mooring cell, simulating the channel. The area in back of the booms was filled with irregularly shaped pieces of plastic ice. The area between the booms was filled with the 4-in. uniform squares of plastic ice. During the test, all of the model ice cleared the channel, partly because the ice booms were flexible enough to prevent theice blocks from arching and stopping the ice flow. Had the channel remained rigid, arching might have been experienced.

Test 6 was the first with the gates in the new location, and the first using randomly shaped freshwater ice. The gate settings were established at a total opening of $13.5 \mathrm{ft}$ (full scale). An ice channel was broken out that was approximately $120 \mathrm{ft}$ wide (full scale) in front of the submergible gates and extended to an area between the first and second mooring cell. After the initial conditions were set, the irregularly shaped, broken ice was allowed to pass. The ice arched in the channel approximately $700 \mathrm{ft}$ upstream from the gates. This arch was easily broken by the passage of a model barge in the ship track. Once the initial arch was broken, the flow in the ice channel was such that a second arch never formed. Figure 7 shows the resulting velocity profile.

Test 7 was conducted with an equivalent fullscale ice thickness of $1.3 \mathrm{ft}$. This test indicates that, with simulated barge traffic, a clear passage can be

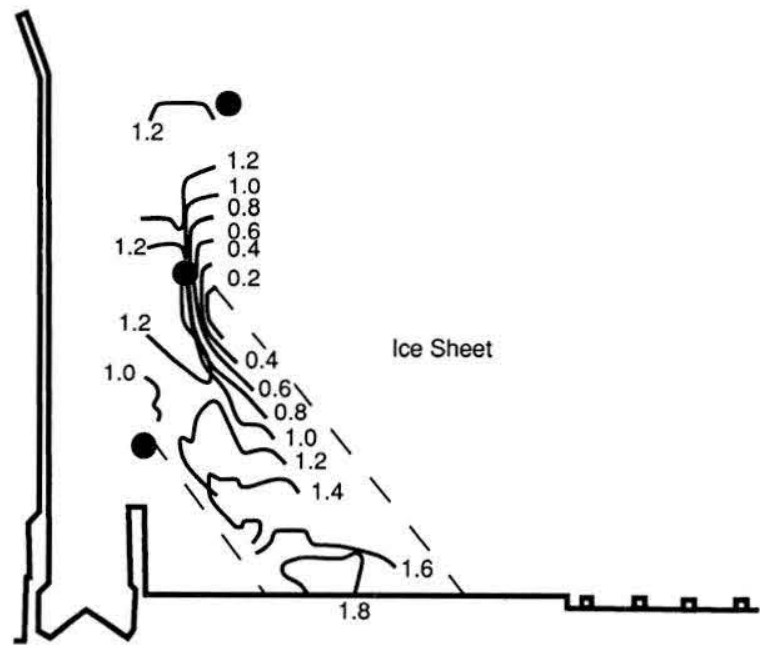

Figure 7. Velocity profile (ft/s) with two submergible gates, each with a 6.7-ft opening and a 120-ft ice channel (all full scale) at position 2. 
maintained to the submergible tainters in position 2.

Test 8 was the initial test to compare how well ice passed through a channel of half the width of that used in test 6 . Both submergibles were set at the standard $6.75 \mathrm{ft}$ but the ice channel was only broken out to a width of approximately $60 \mathrm{ft}$ (full scale). In the initial period of the test, the ice arched closer to the gates than previously noted, and arching continued even after the initial arch was broken. The ice passed freely again once the channel was widened to $120 \mathrm{ft}$.

Test 9 was conducted at a lower room temperature, which caused some difficulties. First, we noted that once the ice had been broken it would quickly knit back together. Also, we noticed that the barge had a much harder time maneuvering in the ship track. The ice was more inclined to form larger pancakes, yet would be broken into smaller floes upon impact with the dam piers and could pass over the gates easily.

Test 10 was a comparison test between the submergible tainters in position 2 and the tainter gates in position 1 . After theice test, surface velocity measurements were taken for the submergible tainter (Fig. 7) and the tainter gate in position 1 (Fig. 8).

Test 11 was conducted with Donald Bycznski, Lockmaster, and Edward Leuch, Assistant Chief, Project Operations, Rock Island District, present.

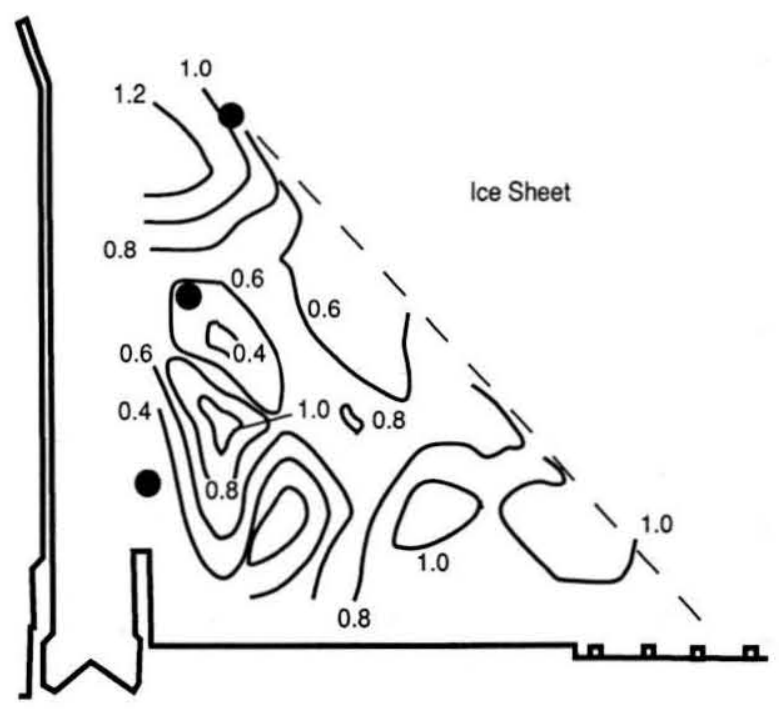

Figure 8. Velocity profile (ft/s) of a single tainter gate with a 4-ft gate opening (full scale) and an ice channel open to the third mooring cell.

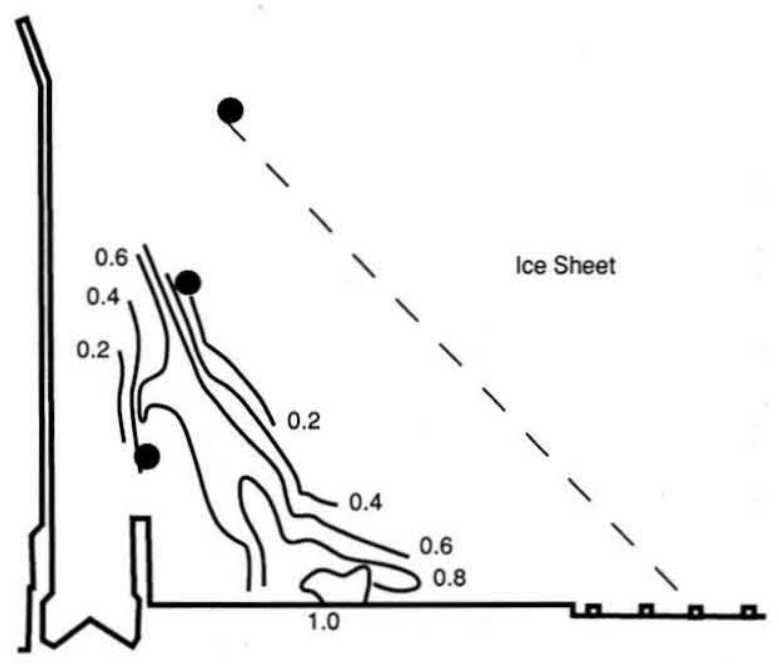

Figure 9. Velocity profile $(\mathrm{ft} / \mathrm{s})$ with two submergible gates, each with a 3.3-ft opening (full scale) at position 2.

The room temperature was $25^{\circ} \mathrm{F}$, which was typical of most of the tests. A sequence identical to test series 10 was conducted. Initially, the submergible gates in position 2 were operated after the ice was broken. The barge made several trips up and down the river to simulate normal traffic. After the ice had cleared from part of the ship track, a channel was broken to the tainter gate in position 1 , which was opened after the two submergible gates were closed. We noticed that flow velocities were much lower and the ice could not pass as freely as when the submergible gates were open in position 2 .

Test 12 examined a reduced flow of 315 gal./ $\min \left(1972 \mathrm{ft}^{3} / \mathrm{s}\right.$ full scale). Our primary purpose was to monitor the ice passage over a full-scale submergible gate opening of $3.4 \mathrm{ft}$ per gate. Ice continued to pass over in spite of the reduced velocities (Fig. 9).

\section{SUMMARY}

Our first five tests were conducted at location 1 , the existing location of the tainter gates at Starved Rock Lock and Dam. Tests 6-12 moved the submergiblegates to location 2. Ice flushing improved greatly with the submergible gates at this location. Velocities more than doubled, and a $30 \%$ decrease in the broken ice surface area would result if a clear channel was maintained for ice passage. The final test reduced the two submergible gate openings to a total of $6.75 \mathrm{ft}$. The flow was reduced to $315 \mathrm{gal}$./ $\min \left(1972 \mathrm{ft}^{3} / \mathrm{s}\right.$ full-scale). The tainter gate open- 
ing for this flow would be about $1 \mathrm{ft}$. Even with this reduced flow, ice could pass over the crest of the submergible gates.

A model tow barge simulated the effect of river traffic on fragmented ice. This disruption of the ice helped heavy ice concentrations move toward the gates. We did not simulate the propeller wash effect that would go along with barge and tow boat traffic, but this additional flushing would only improve ice conveyance. We evaluated ice passage through a previously cut $60-\mathrm{ft}$ channel. Because of the arching of the broken ice in this channel, this width had to be increased to $120 \mathrm{ft}$ to allow efficient and continued ice passage.

\section{CONCLUSIONS AND RECOMMENDATIONS}

The model study of Starved Rock Lock and Dam has shown conclusively that submergible gates will effectively pass more ice than the exist- ing tainter gates. Flow velocities immediately upstream of each gate type showed no appreciable difference from one gate style to another. The major advantage of the submergible gate is that it provides three times the flow depth for the same discharge and pool elevation, allowing for easier ice passage. This in turn would mean less icebreaking requirements from the shipping channel to the dam gates, more ice removal from the shipping channel lock approach area and an overall improvement in ice management for winter navigation. Gate icing problems may also be reduced with the use of submergible dam gates. Simulated barge traffic increased ice movement towards the dam gates, resulting in an ice-free channel from the shipping lane to the dam gate.

We feel that submergible gates located at the second location, which is closer to the lock chamber, will prevent ice problems in the lock approach and allow efficient and timely winter operations at Starved Rock Lock and Dam. 


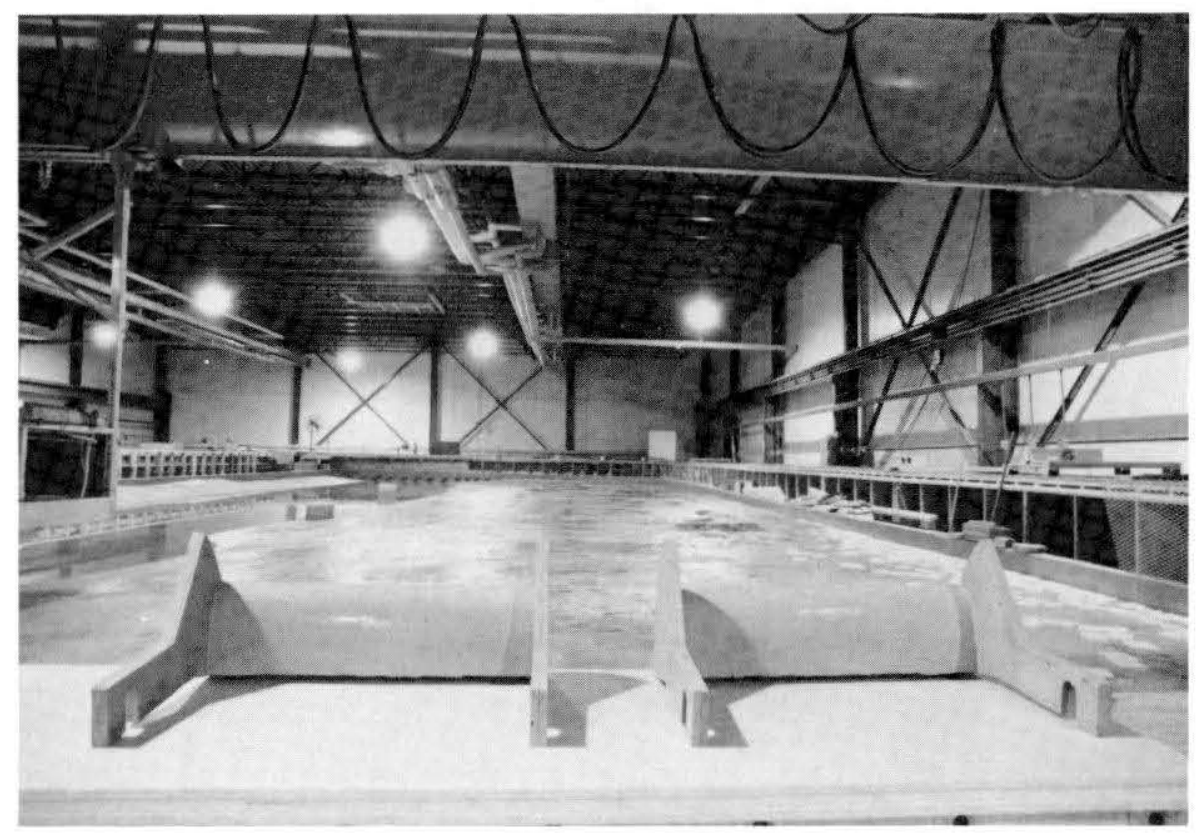

Figure A1. Submergible gates before installation.

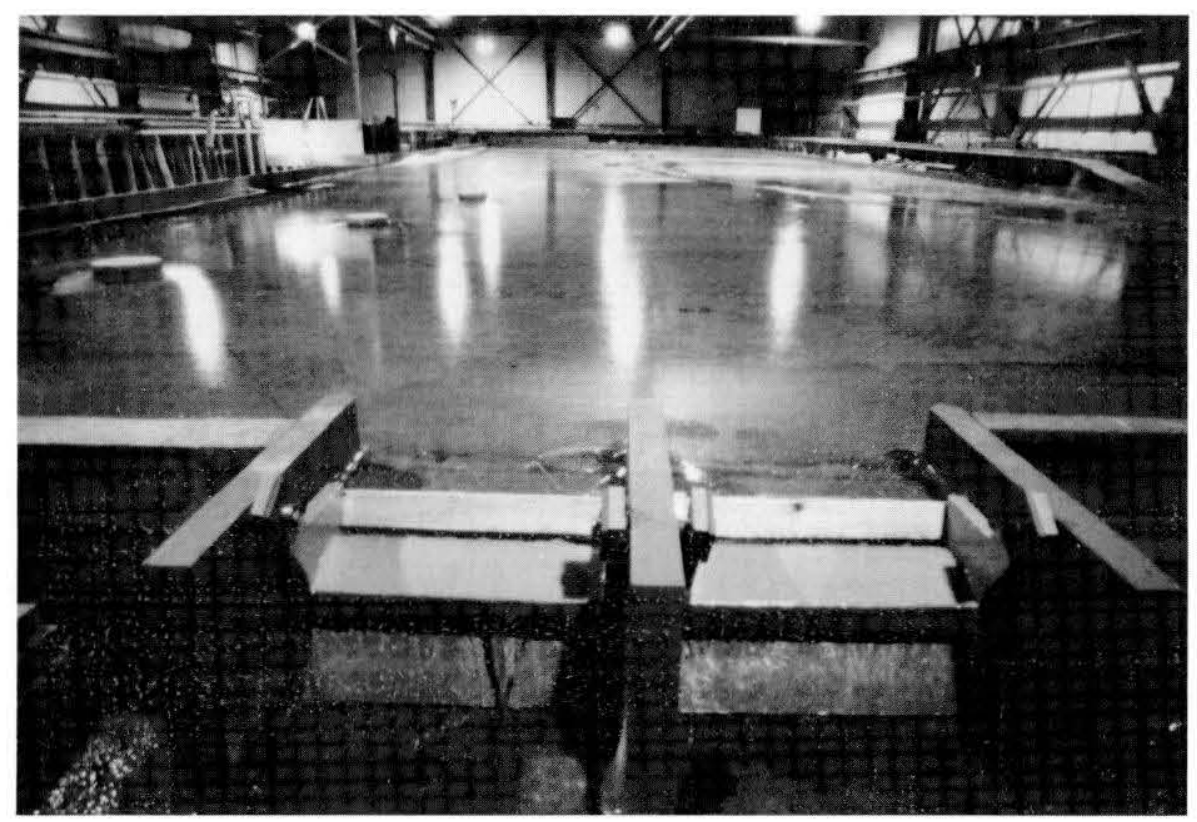

Figure A2. Installed submergible gates, site 2, with unbroken ice cover. 


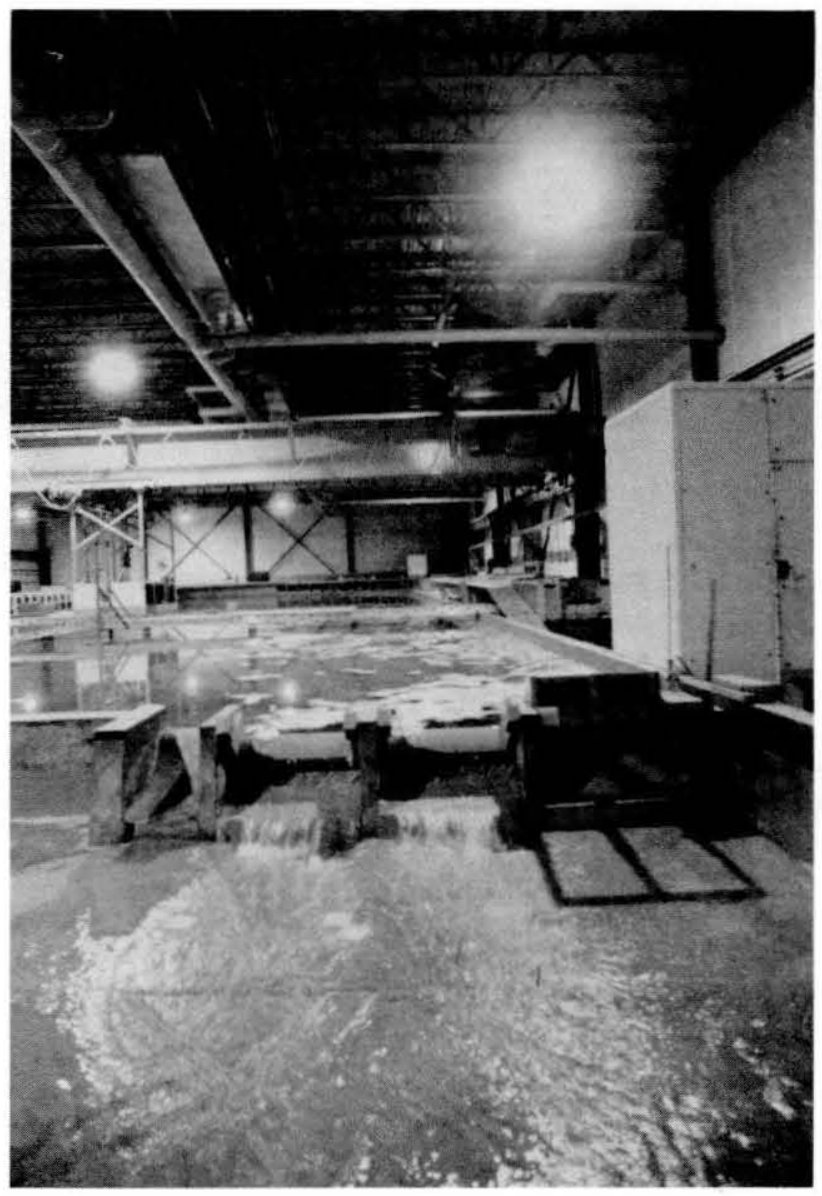

Figure A3. Submergible gates at site 1, with plastic ice.

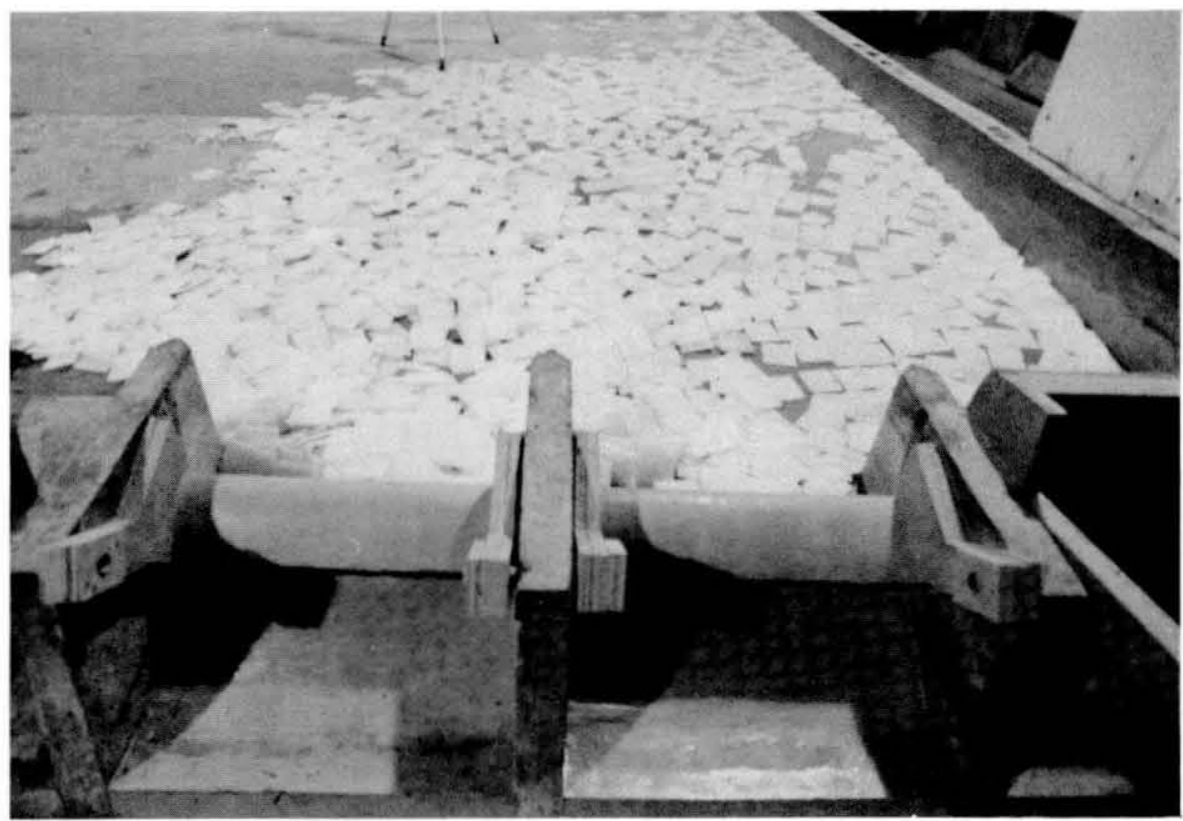

Figure A4. Submergible gates at site 1, gates submerged, plastic ice. 


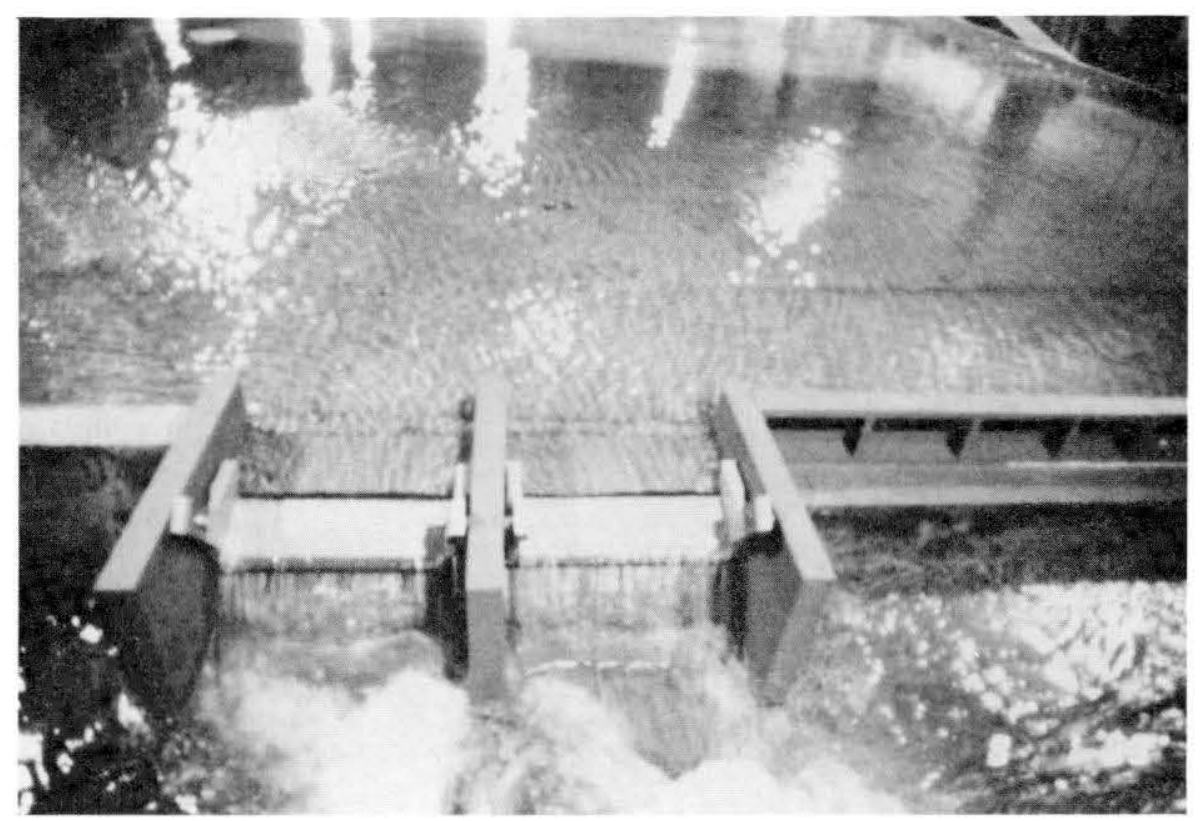

Figure A5. Open-water flow calibration, submergible gates at site 2.

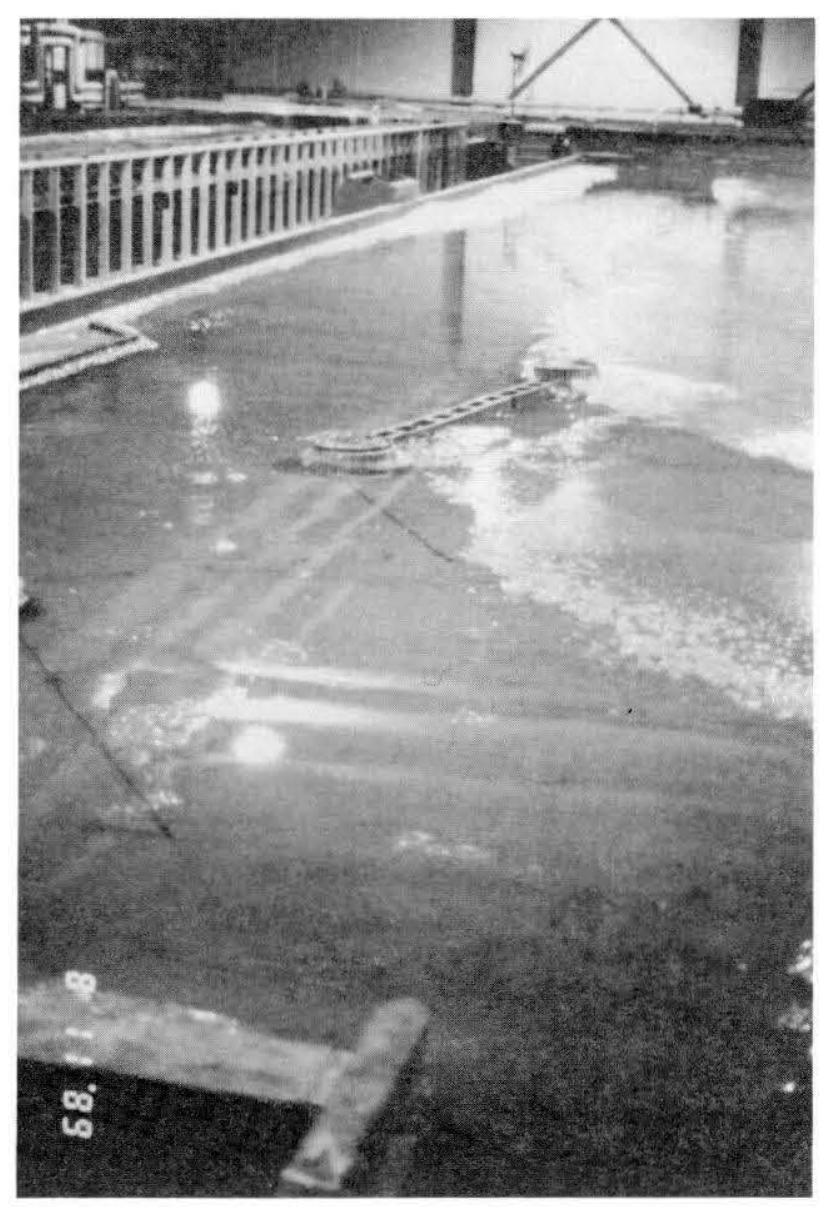

Figure A6. Ice cover intact; shipping channel on left, mooring cells in center, submergible gate pier at bottom center, flow diversion with blocks between cells. 

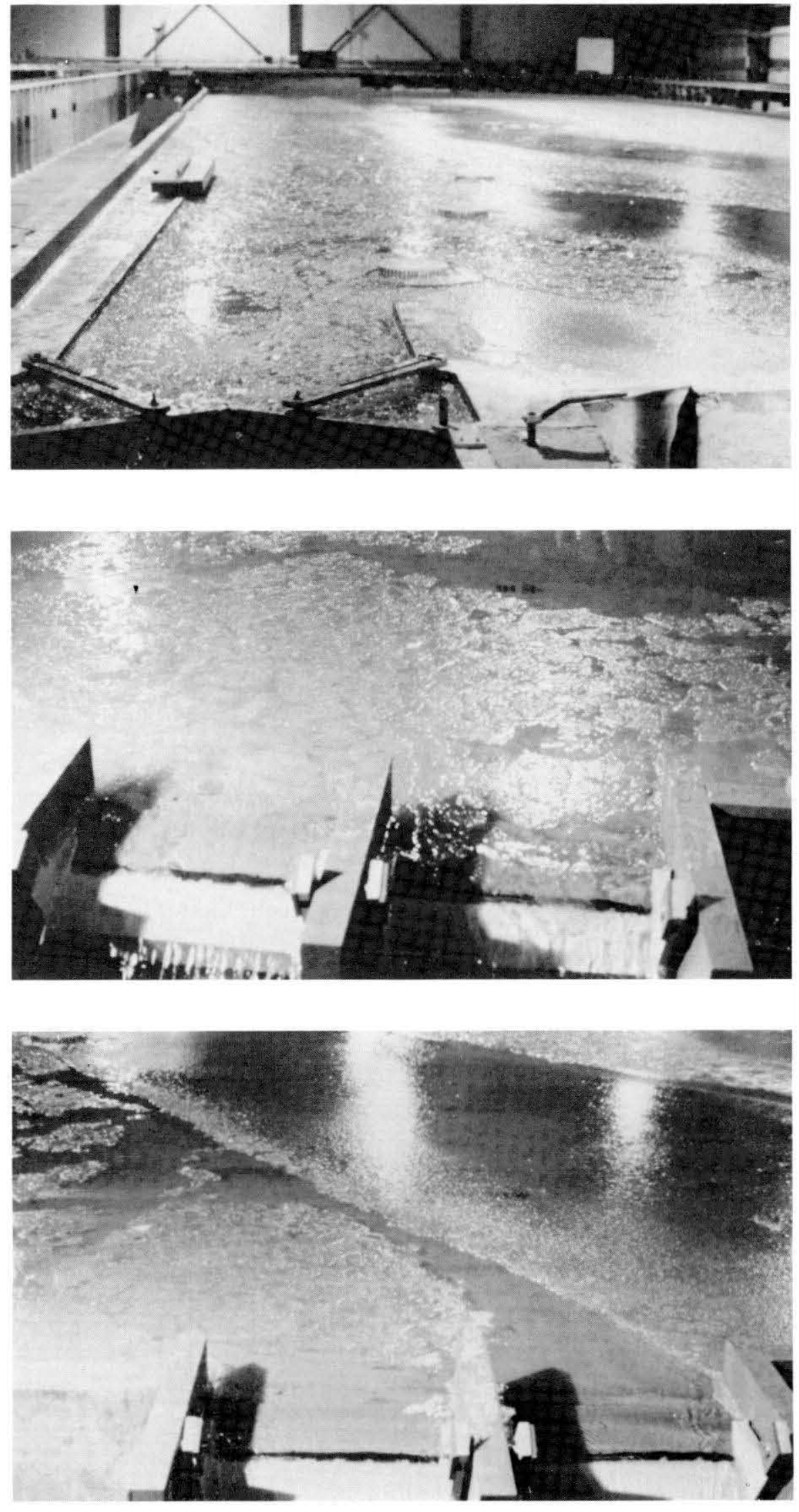

Figure A7. Ice cover broken in shipping channel and in ice clearing channel from shipping channel to dam gates, before testing.

Figure A8. Ice passage over submergible gates at site 2.

$a$.

b. 


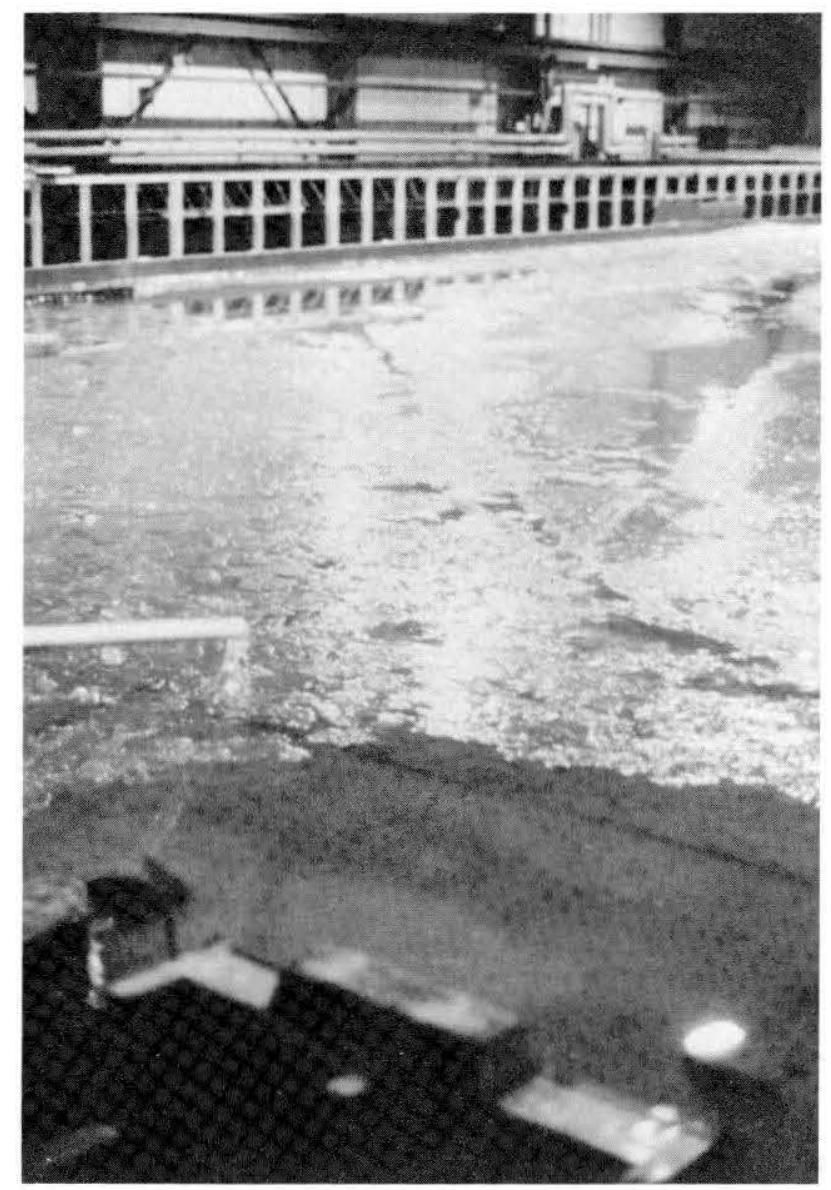

Figure A9. Arching of broken ice cover above dam gates, low-flow winter conditions.

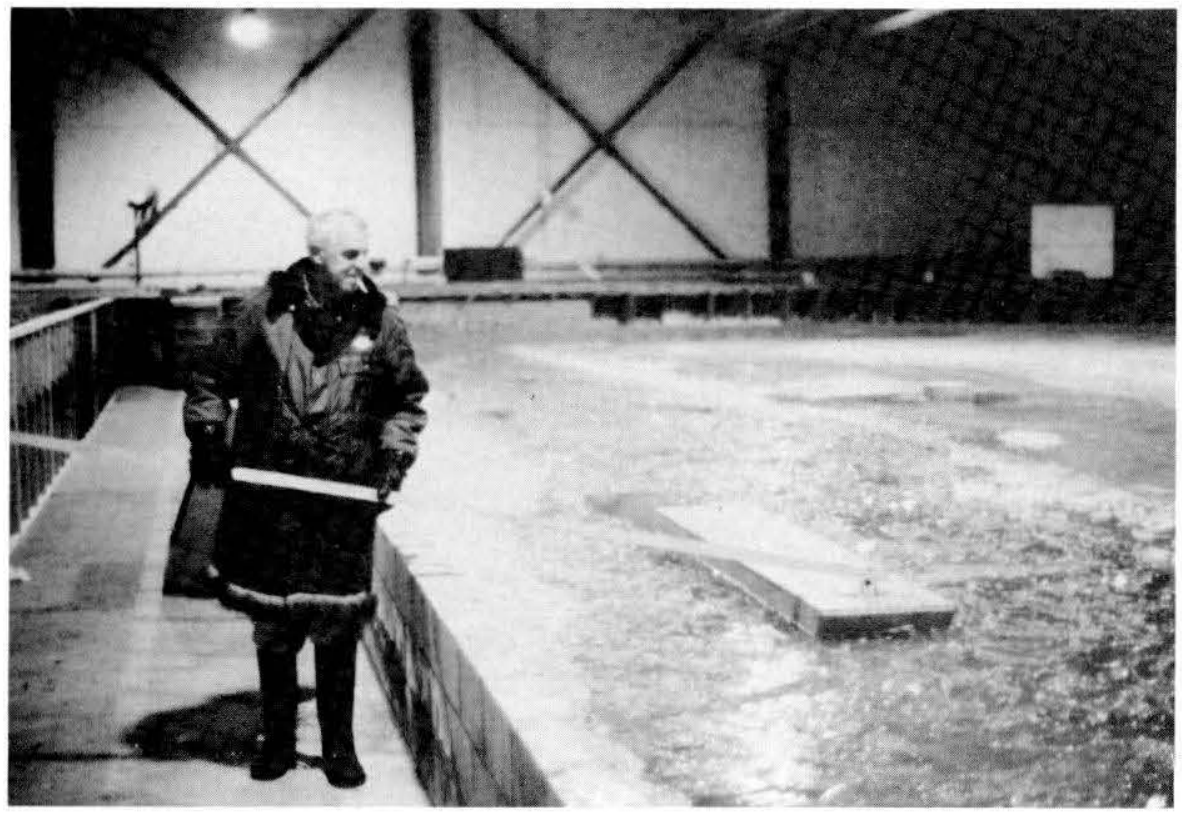

Figure A10.Tow boat Capt. "Buz" simulating one-barge traffic. 


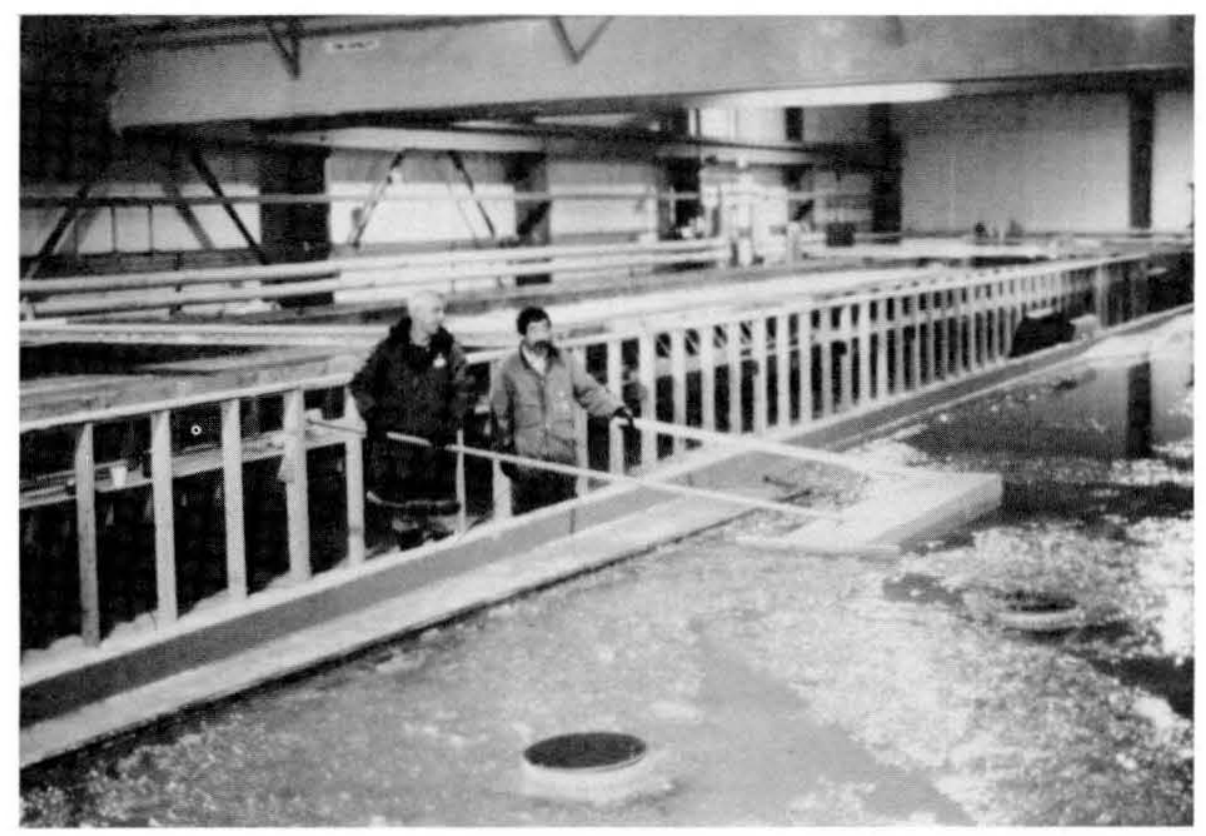

Figure A11. Simulated two-barge traffic.

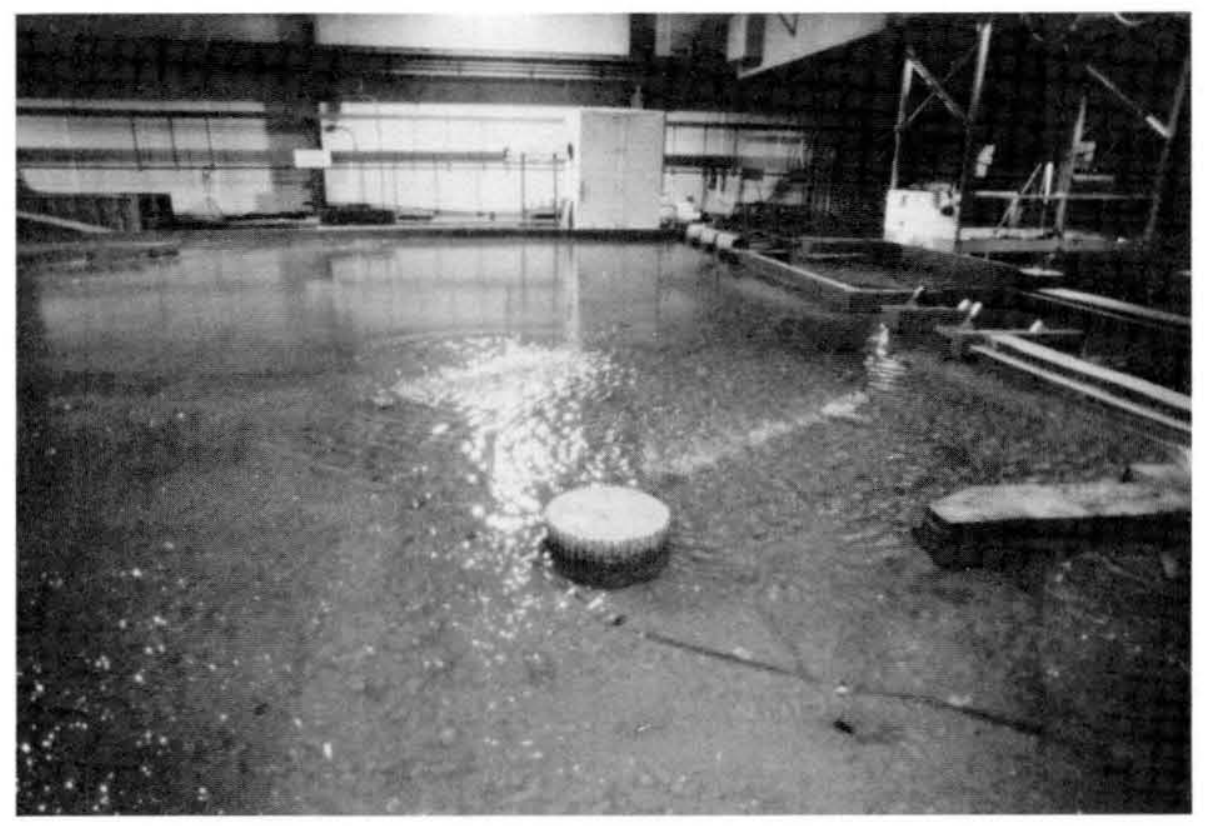

Figure A12. Simulated air bubblers in clearing channel above dam gates; ice-free conditions during ice cover buildup prior to testing. 


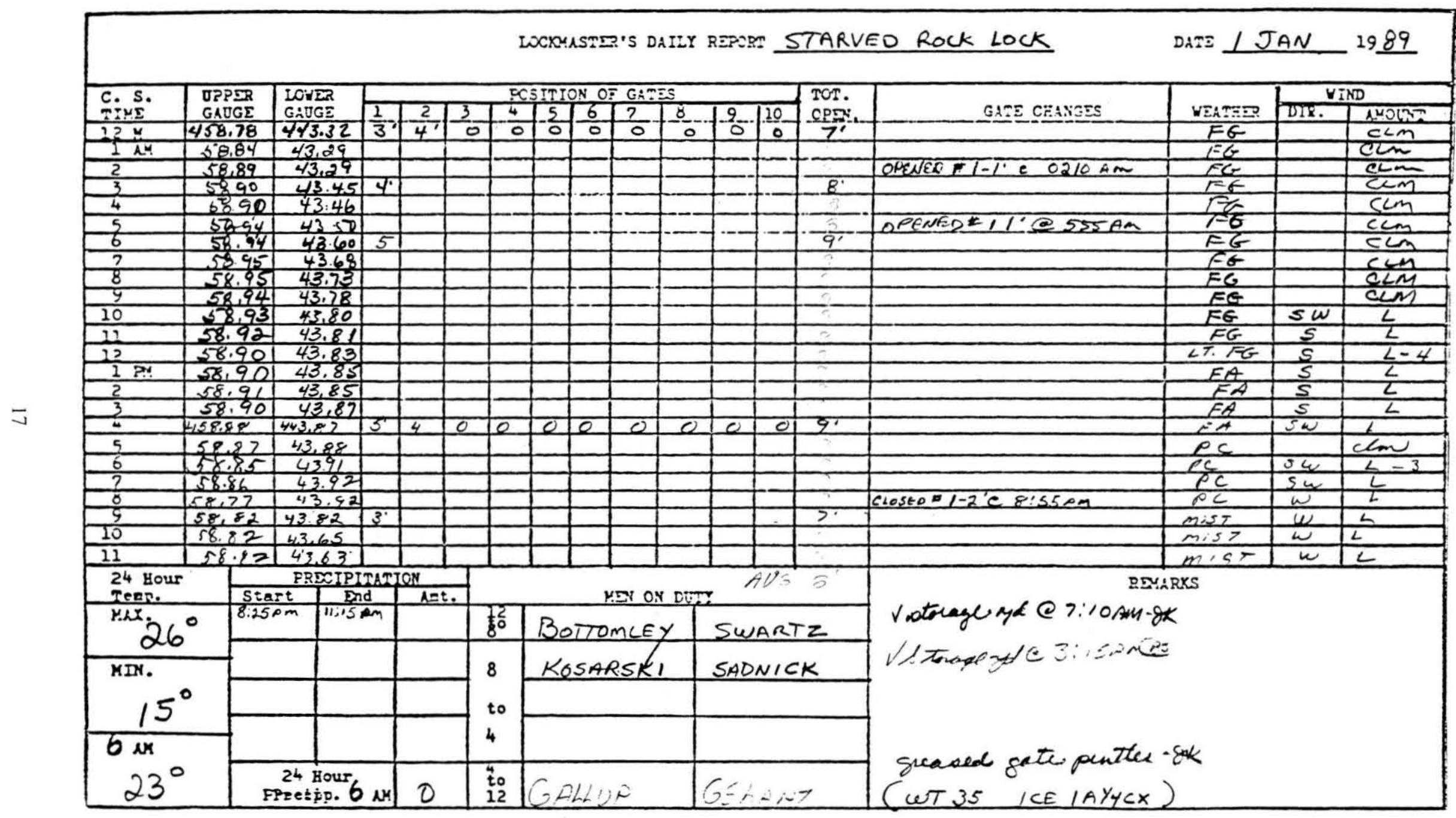


WCKMASTES'S DAILY REPOR STARVED ROCK LOCK DATE 2 JAN 1989

\begin{tabular}{|c|c|c|c|c|c|c|c|c|c|c|c|c|c|c|c|c|c|c|}
\hline c. 5. & & & GeV $100-1$ & & & & $\frac{5}{4}$ & 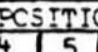 & ON OE & GATE & & & & TOT. & & & & IND \\
\hline$\frac{145}{125}$ & $\frac{G A}{45}$ & & $-\frac{G i d y}{4 x}$ & $\frac{6 E}{3.52}$ & $\frac{1}{3}$ & $\frac{2}{4}$ & \begin{tabular}{l|l}
3 & 4 \\
0 & 0
\end{tabular} & $4-\frac{5}{0}$ & $\frac{6}{0}$ & $\frac{7}{0}$ & $-\frac{8}{0}-$ & $-9-1$ & $\frac{10}{0}$ & & GAZECEANGES & $\frac{\text { VEATEP? }}{\text { MIST }}$ & $\frac{\text { D1R. }}{w}$ & None \\
\hline $1 \sqrt{44}$ & & & & 3.51 & & & & & - & & & & & & & $4 \mathrm{Tm}_{15} 7$ & $\omega$ & \\
\hline & & & & 3.49 & & & & & & & & & & & $2-12025$ & $=-46$ & $\frac{\pi}{2}$ & $m$ \\
\hline$\frac{3}{4}$ & $\frac{58}{54}$ & & & $\frac{3,48}{3,44}$ & & & & & $\ldots$ & & & & - & & $1=-1=$ & 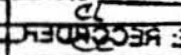 & $\frac{\omega}{\partial A D \omega}$ & $m$ \\
\hline 5 & & & & 3.38 & & & & & & & & & & 42 & OPCNEO $\triangle 1, T^{\prime}=$ SWOAE CSDI & $J C L$ & Eine & $\frac{m}{M}$ \\
\hline 6 & 58 & & $\frac{4}{4}$ & & $4^{\prime}$ & & & & & & & - & -1 & 8,9 & opawrota l $^{1}$ te $6.5 n$ & & $w$ & $m-14$ \\
\hline & 58 & & & $\frac{3.60}{10}$ & & $5^{\prime}$ & & & & & & & & 9 & & & $\omega$ & L \\
\hline 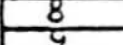 & 58 & & & $\frac{3.68}{2.68}$ & - & & & 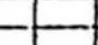 & - & 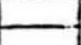 & & & _ & & & $\frac{P}{C}$ & $\frac{\pi \omega}{N \omega}$ & $2-8$ \\
\hline 10 & $\frac{58}{58}$ & & & 3,73 & & & - & & - & & & & & - & closedaz-2'0loilsA & $C L$ & $\frac{N \omega}{N \omega}$ & $\frac{1}{L}$ \\
\hline 21 & 58 & & & 3,50 & & $3^{\prime}$ & & & & & & & & $z^{\prime}$ & & & Nu & \\
\hline 12 & 58 & & & $\frac{3,43}{2,30}$ & & & & & & & & & & & & $\frac{5}{5}$ & (1) & $2-6$ \\
\hline $1 P 4$ & 58. & & $2 \sqrt{3}$ & 3,38 & & & & & & & & & & & & ec & 10 & \\
\hline$\frac{2}{3}$ & $\frac{58}{28}$ & & $\frac{42}{42}$ & 3,35 & - & - & & & & & & & & & & $c 4$ & $5 w$ & 4 \\
\hline 2 & $\frac{28 .}{458}$ & & $\frac{43}{443}$ & 3,29 & $4 !$ & $3^{\circ}$ & 0 & 10 & 0 & 0 & 0 & 0 & 0 & $z^{\prime}$ & & है & 50 & $\frac{1}{c k m}$ \\
\hline 5 & 58. & & & 23 & & & & & & & & & & & & cl & & chen \\
\hline$\frac{6}{7}$ & $\frac{58}{158}$ & & $\frac{43}{42}$ & .18 & $9^{\prime}$ & 2. & & & & & & & & $\frac{56}{4^{5}}$ & 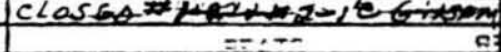 & $\frac{7}{20}=$ & & Clan \\
\hline$\frac{1}{6}$ & $\frac{58}{58}$ & & $\frac{42}{42}$ & $\frac{80}{63}$ & 2, & 2. & & & & & & & & $5 \times 1$ & $=1-1,2$ & $\frac{d e}{2}$ & & elem \\
\hline$\frac{5}{10}$ & 58 & & 42. & 47 & & & & & & & & & & 12 & 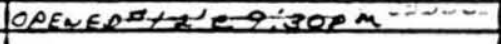 & Fes & & $\cos$ \\
\hline 10 & 58 & & 42. & 60 & $4^{\prime}$ & & & & & & & & & $6^{\circ} 6$ & & al & $s$ & L \\
\hline 11 & 159. & 0 & 42. & 75 & & 4. & & & & & & & & 8.8 & OPENES" 2-2'e llias & e & 5 & L \\
\hline $24 \mathrm{~s}$ & & StE & $\frac{P R}{r t}$ & $\frac{E C I P I}{15 x}$ & Tatid & $e_{N=t}$ & & & & ON ON & 00 & & AUG & $7^{\prime}$ & 25 & & & \\
\hline Yhx. & $2^{0}$ & & & 105 & & & 82 & Bo & $0 \pi 0$ & once & & Sw & IART & $T 2$ & $\checkmark$ storane yed $\in$ o: $50 \mathrm{~A}$ & & & \\
\hline MIN. & & & & & & & 8 & $P_{c}$ & apte & Pl & & So, & pe.s & & te & & & \\
\hline$c$ & & & & & & & to & & & & & & & & & & & \\
\hline $6 \mathrm{Nm}$ & & & & & & & 4 & & & & & & & & & & & \\
\hline & & & $\begin{array}{c}24 \\
\text { Pzet }\end{array}$ & ip. 6 & ب & $T$ & $\begin{array}{l}\text { to } \\
12 \\
\end{array}$ & GAL & 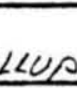 & & & $C=E h$ & ANT & & C wT 34 & $G \hat{f}, \cdots$, & & \\
\hline
\end{tabular}




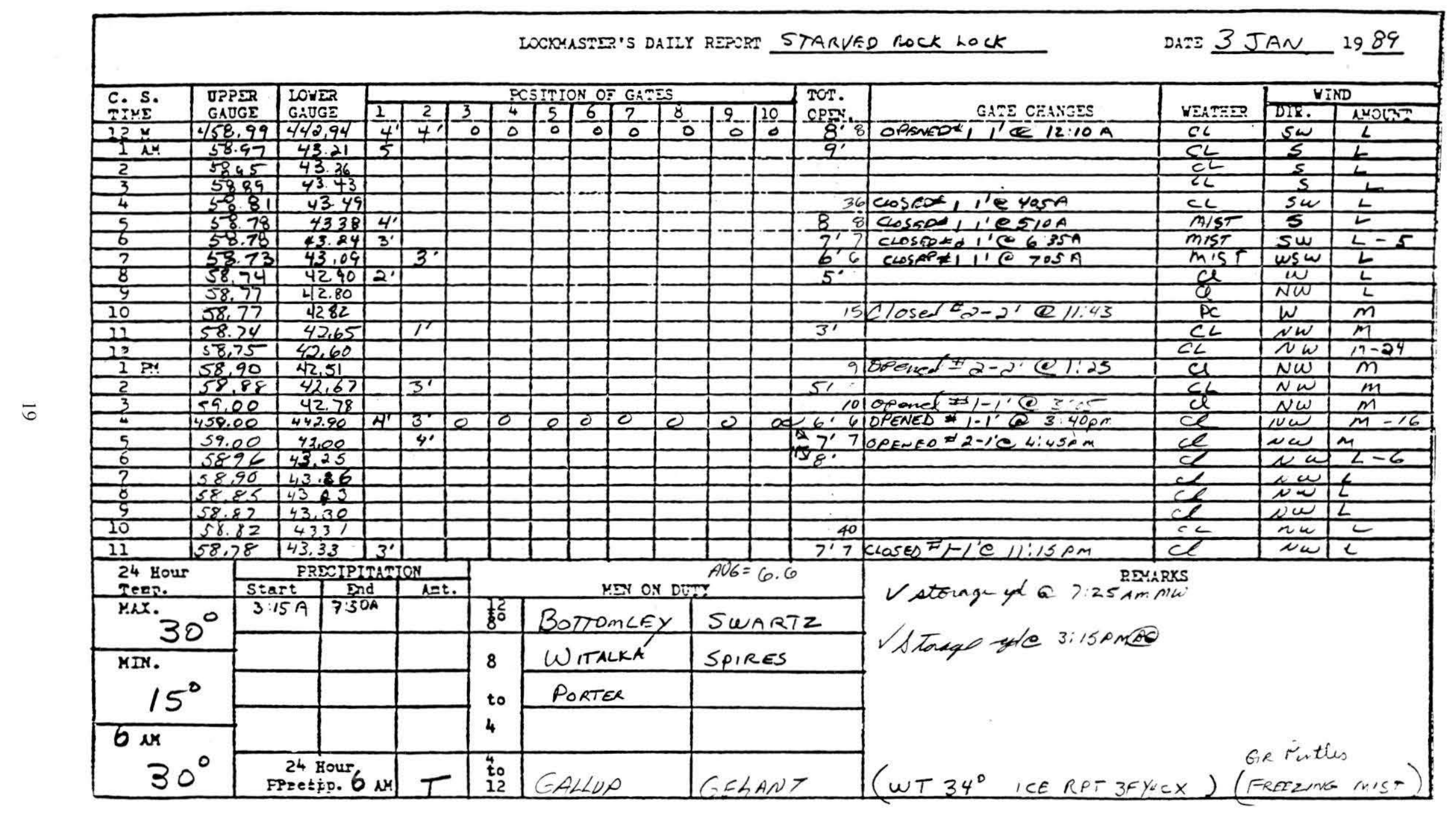




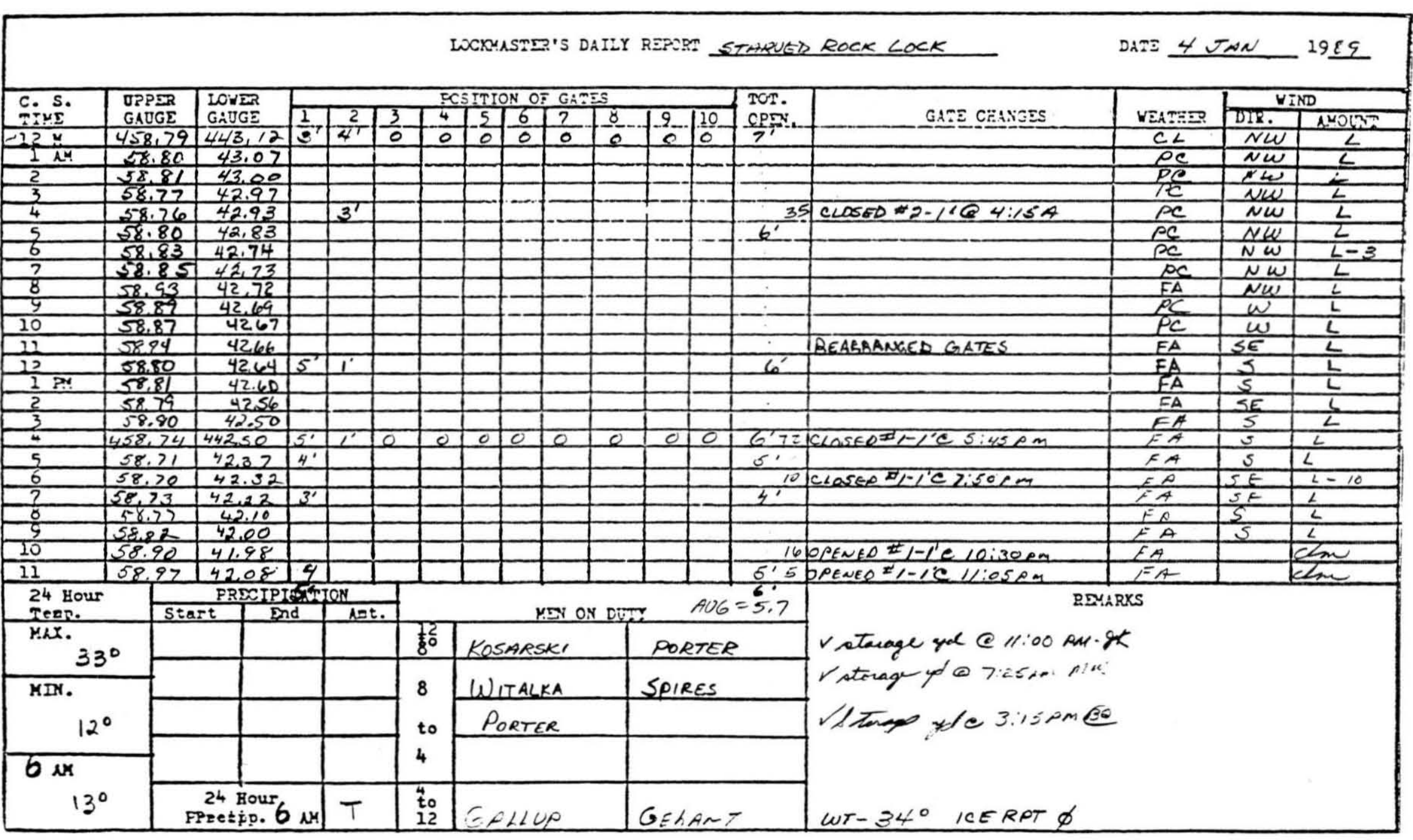




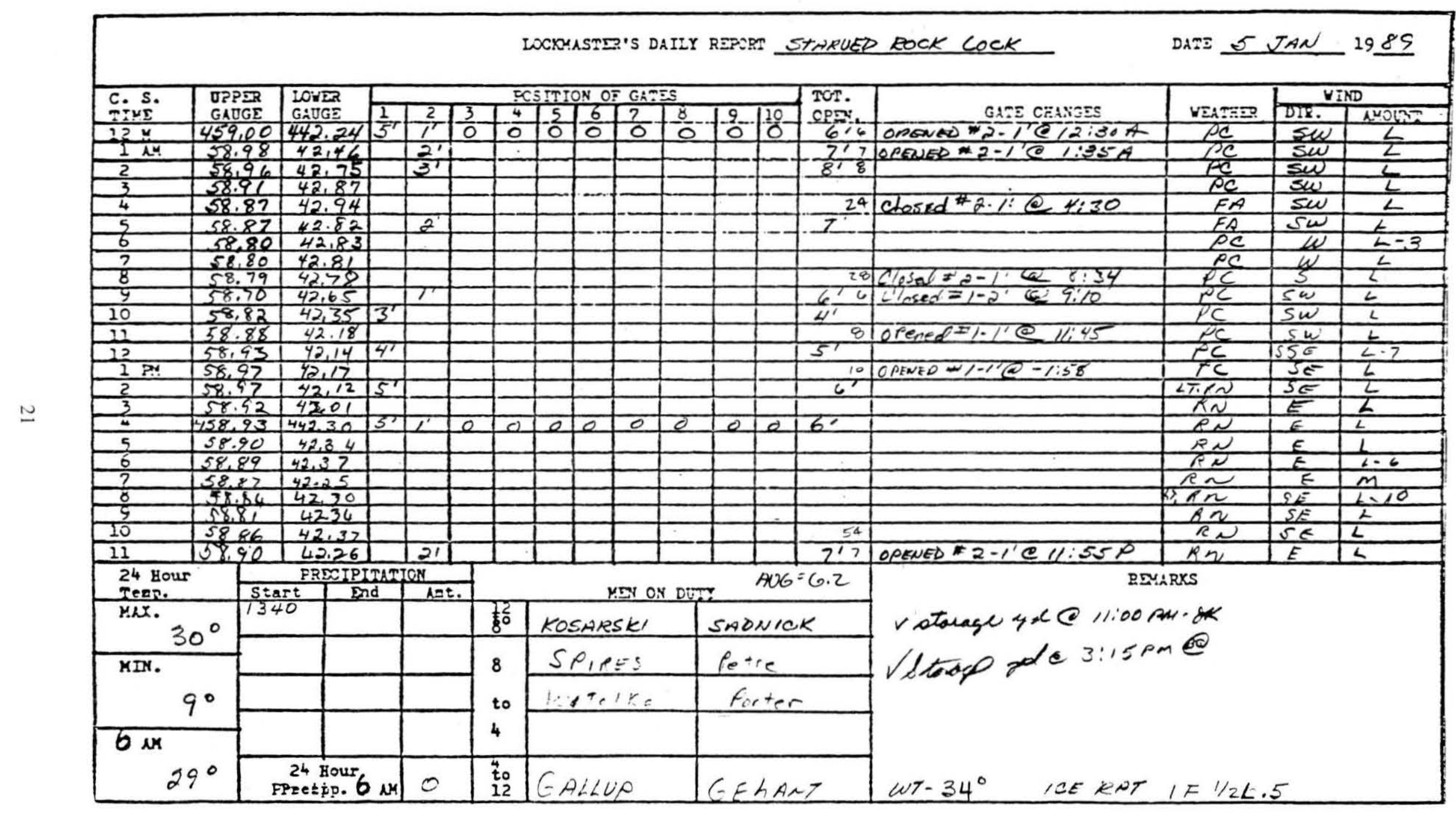




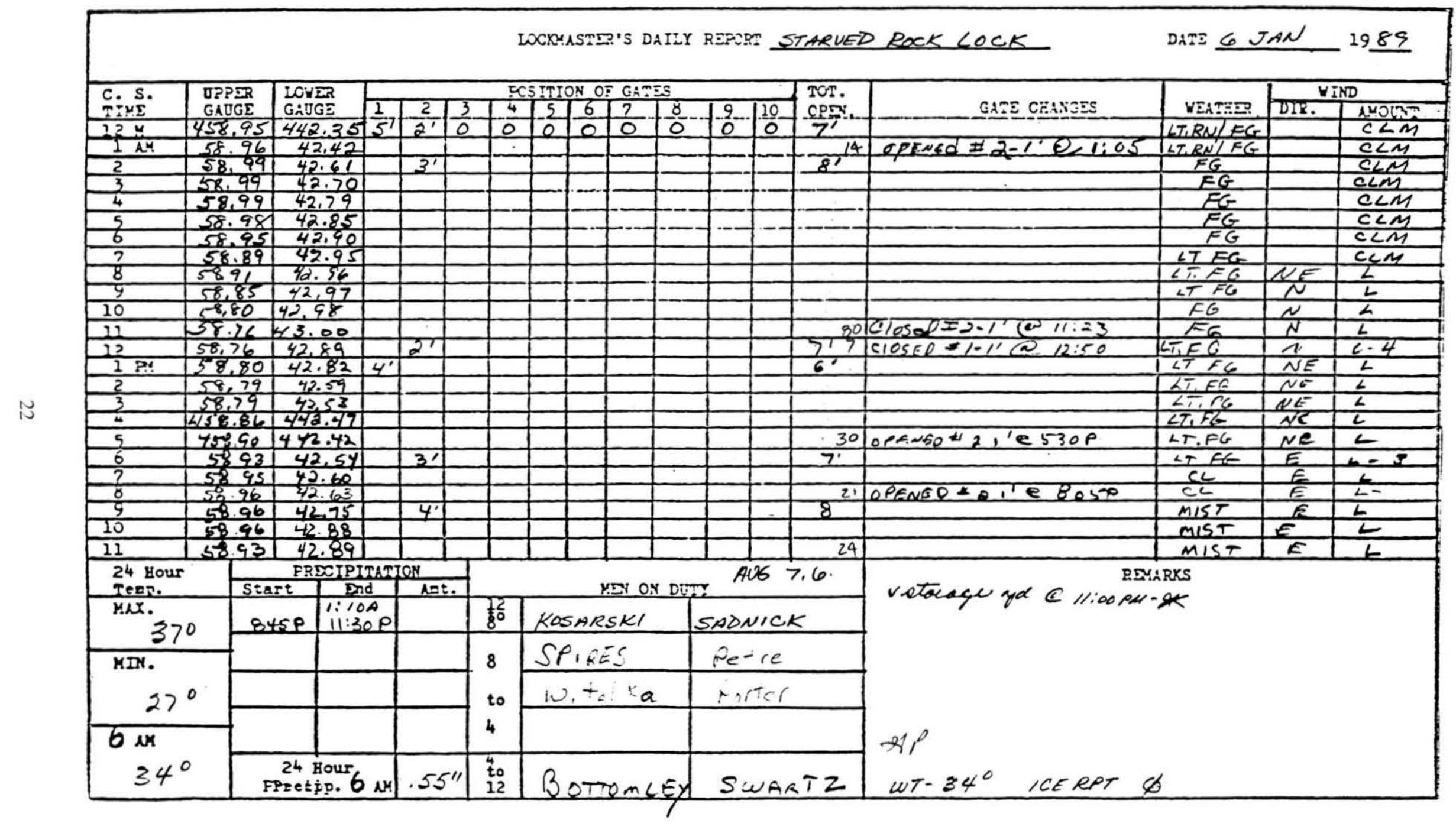




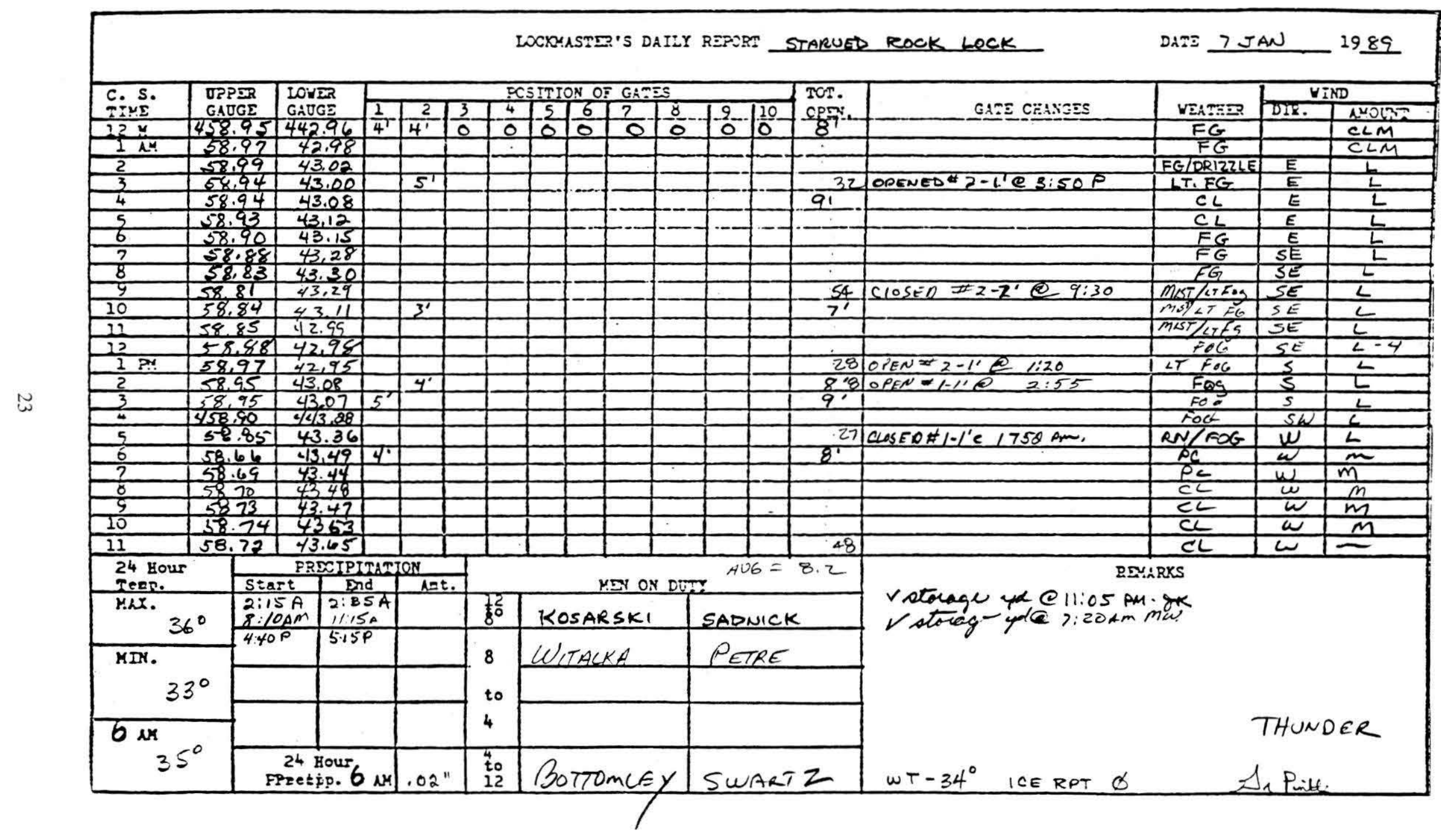




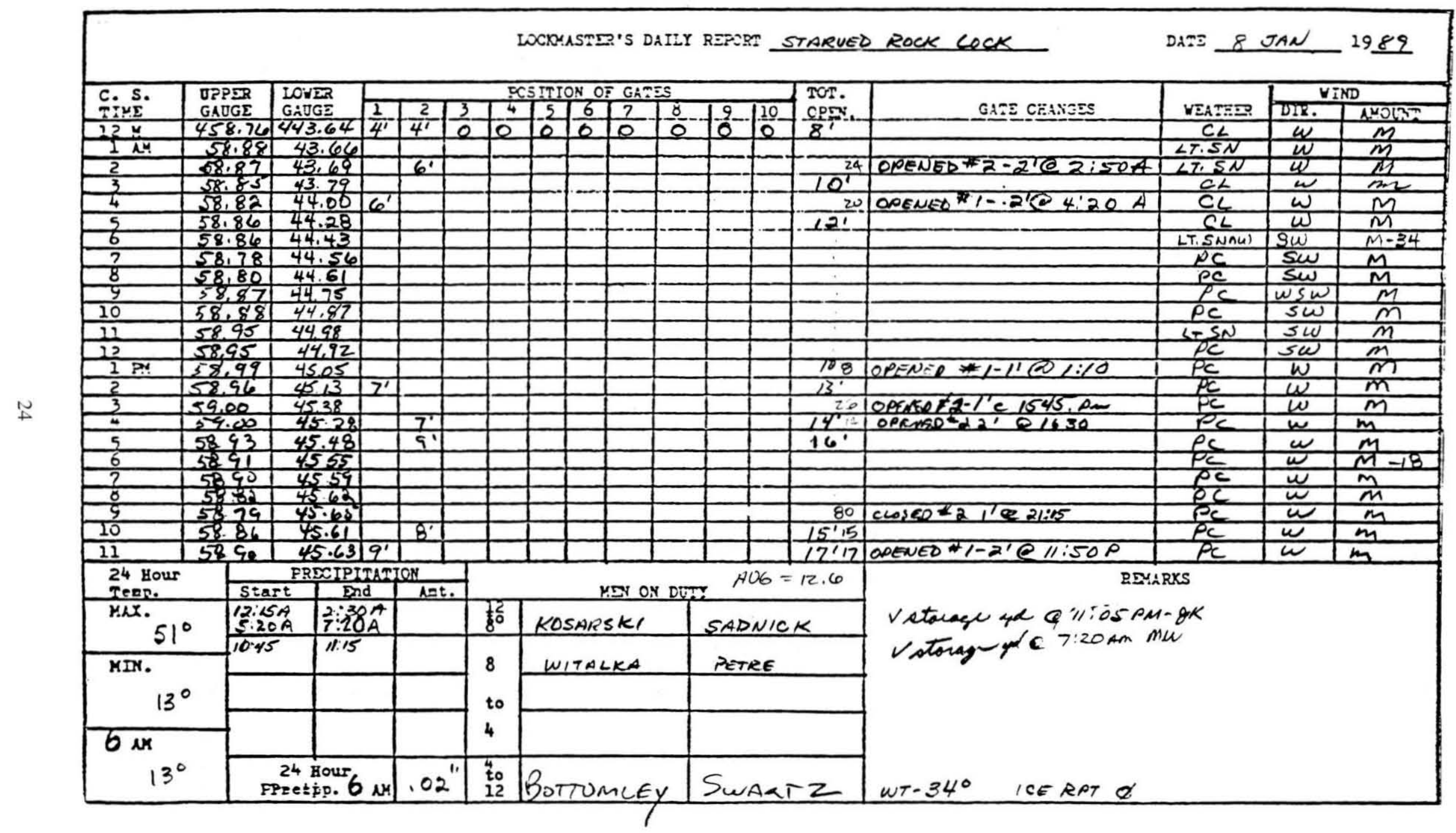




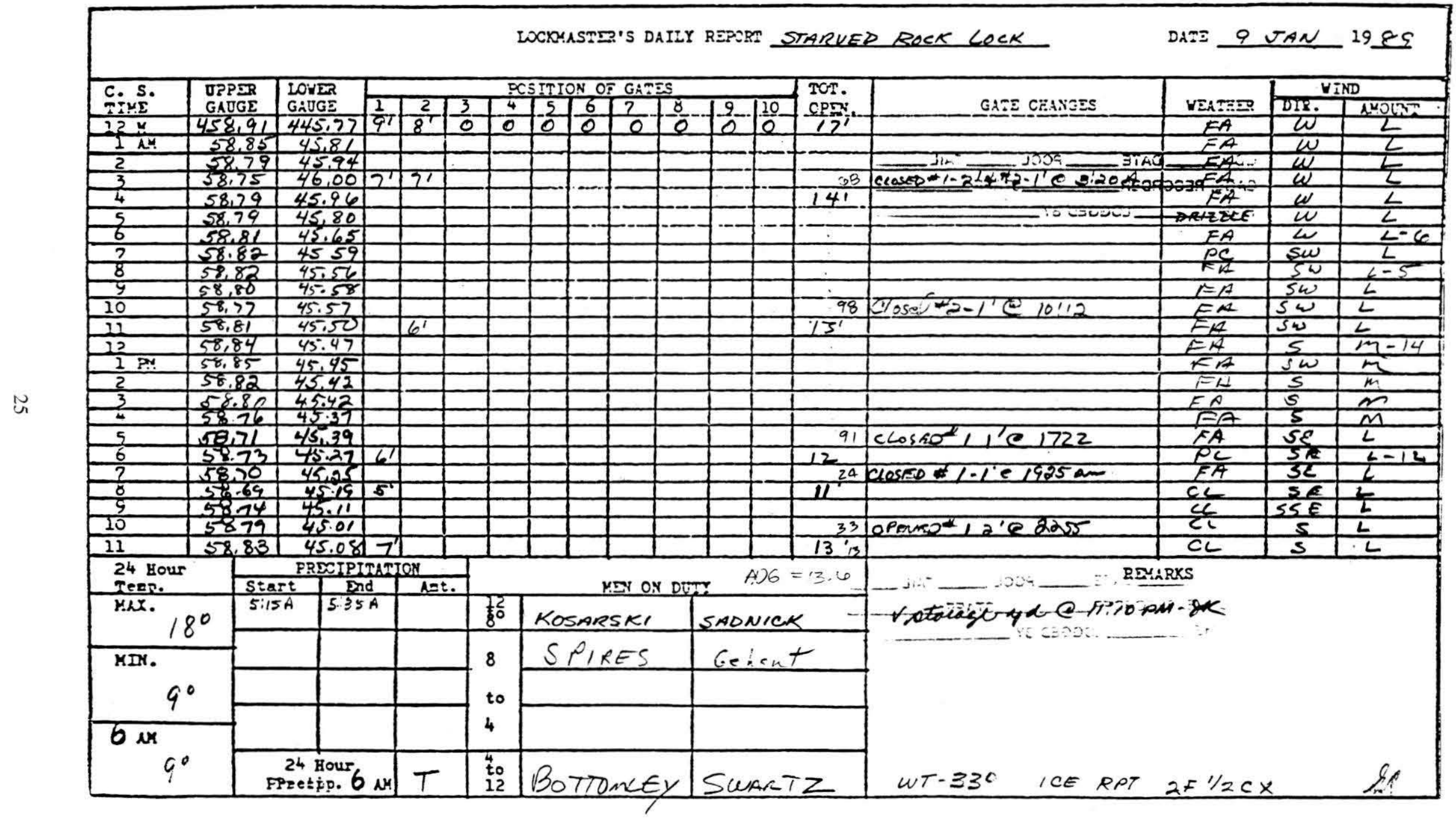




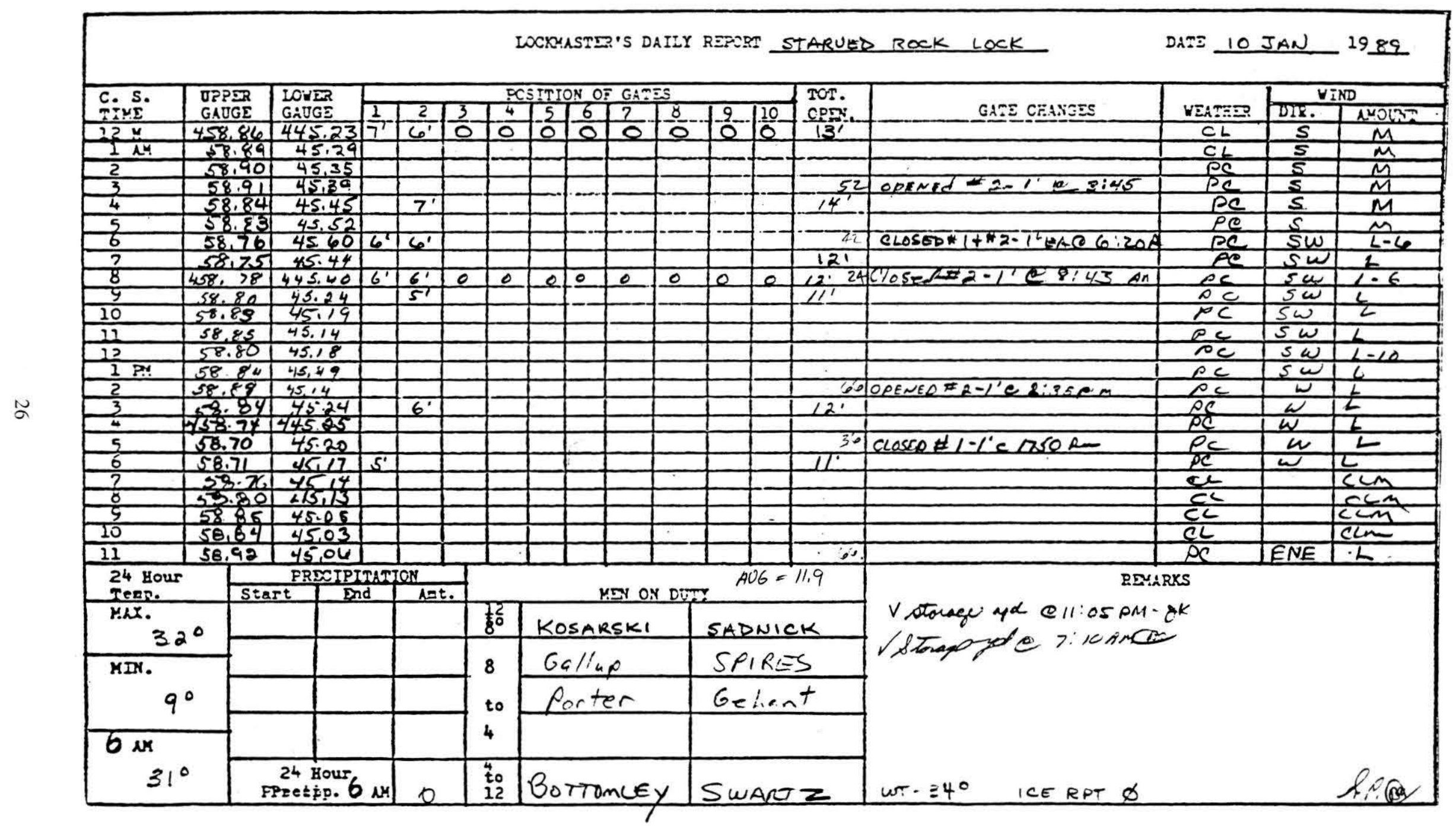




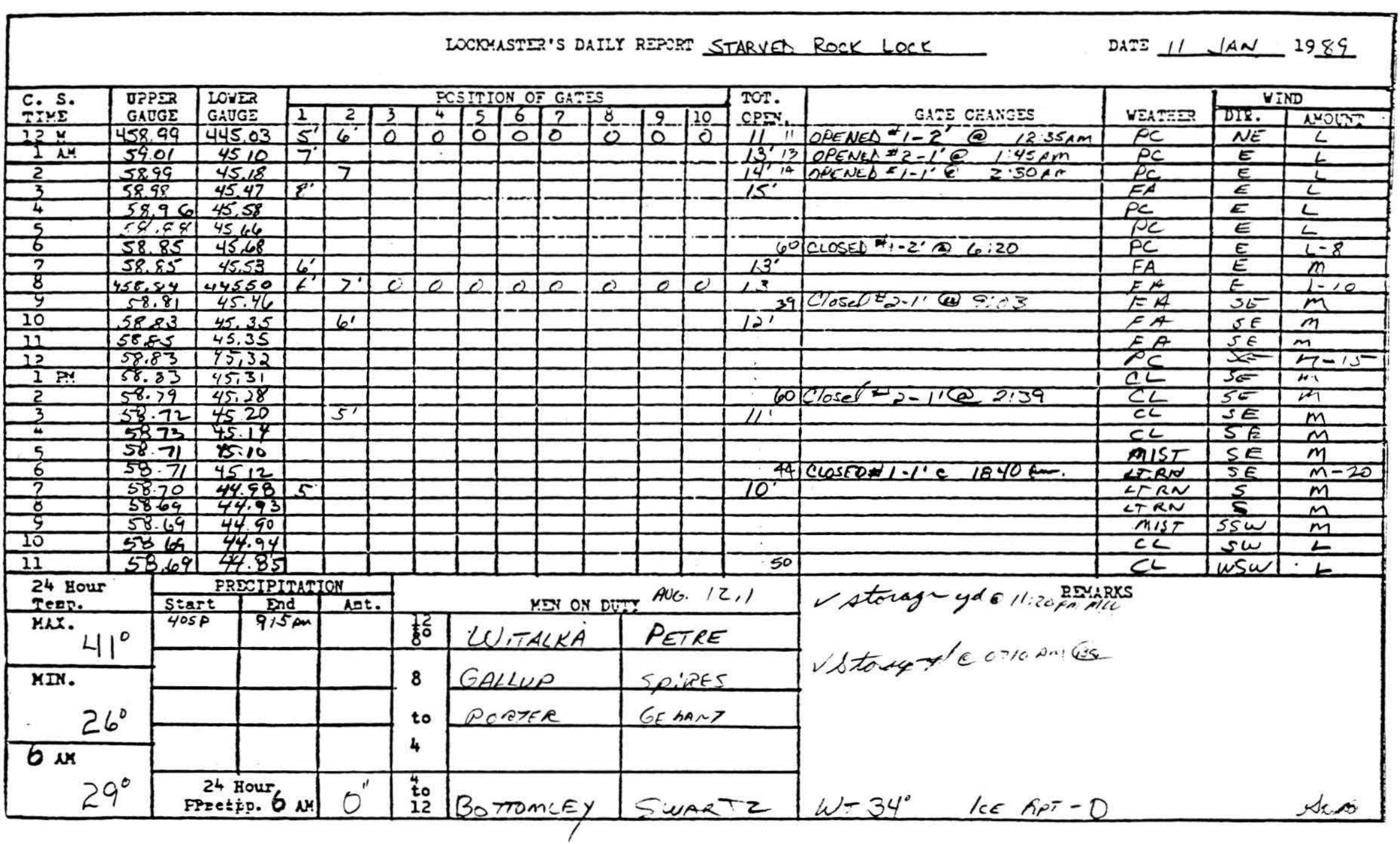




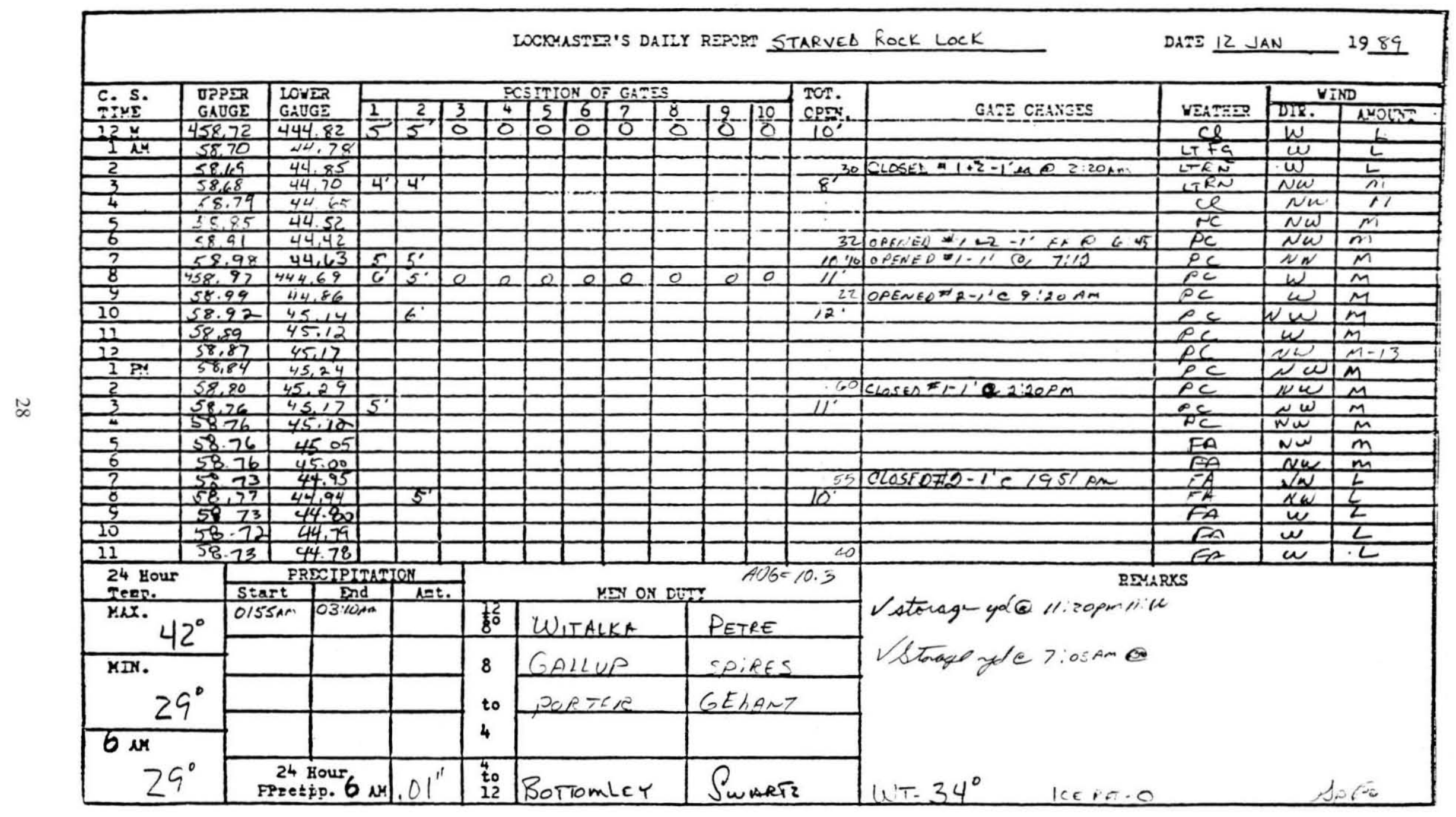




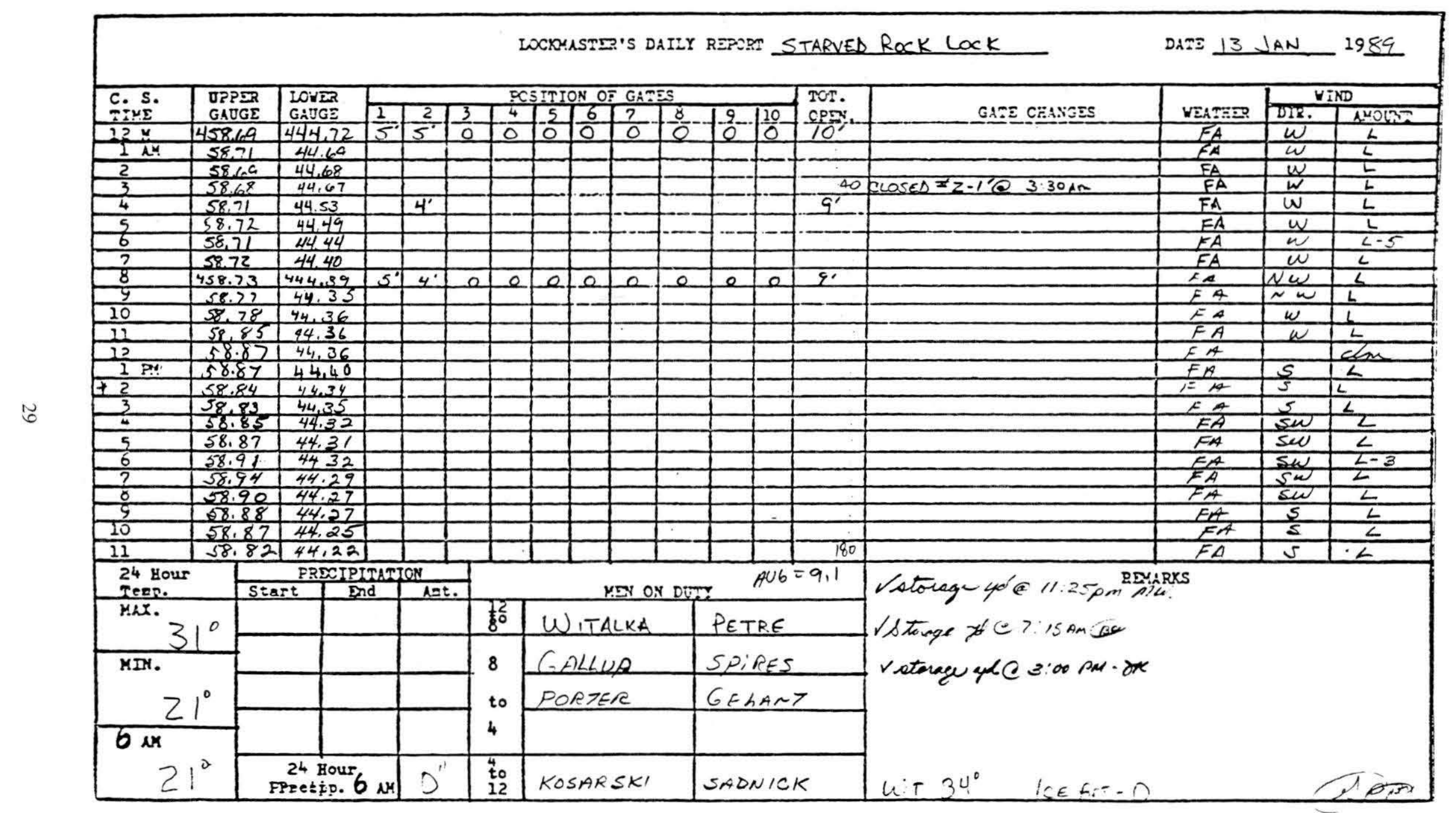




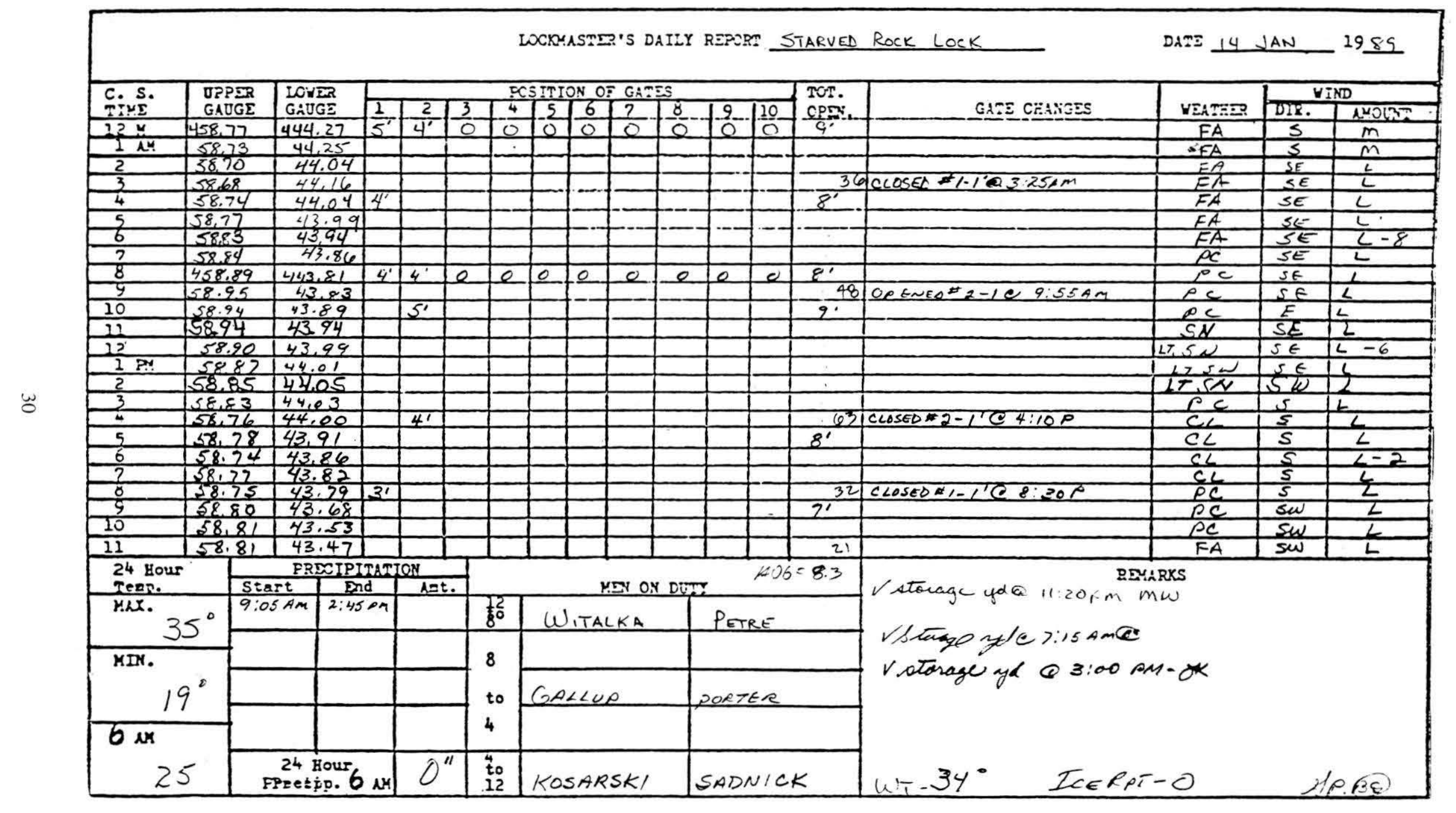




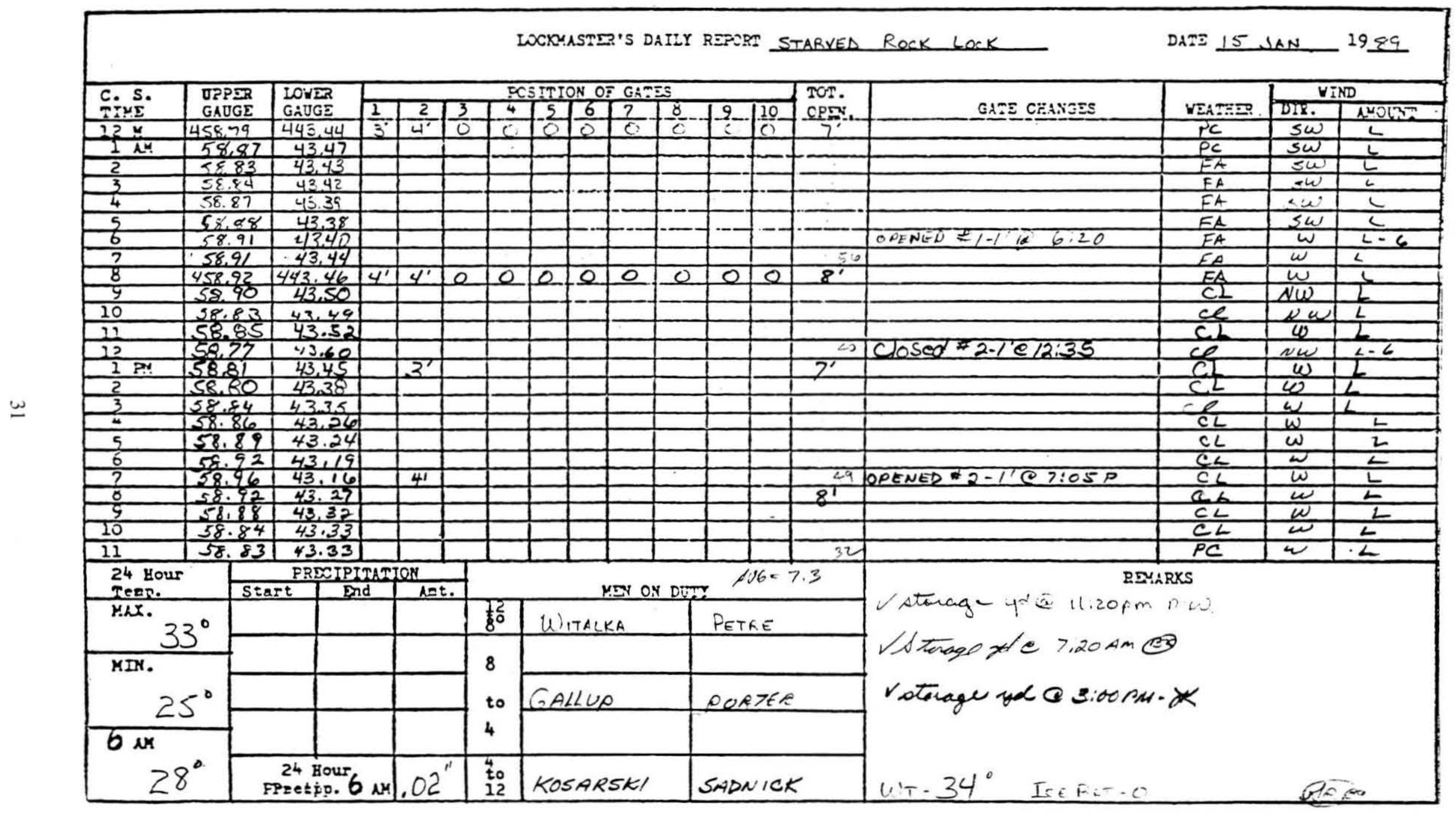


WCKMASTES'S DAILY REPER STARVED ROCK LOCK

DATE 16 J AN

1989

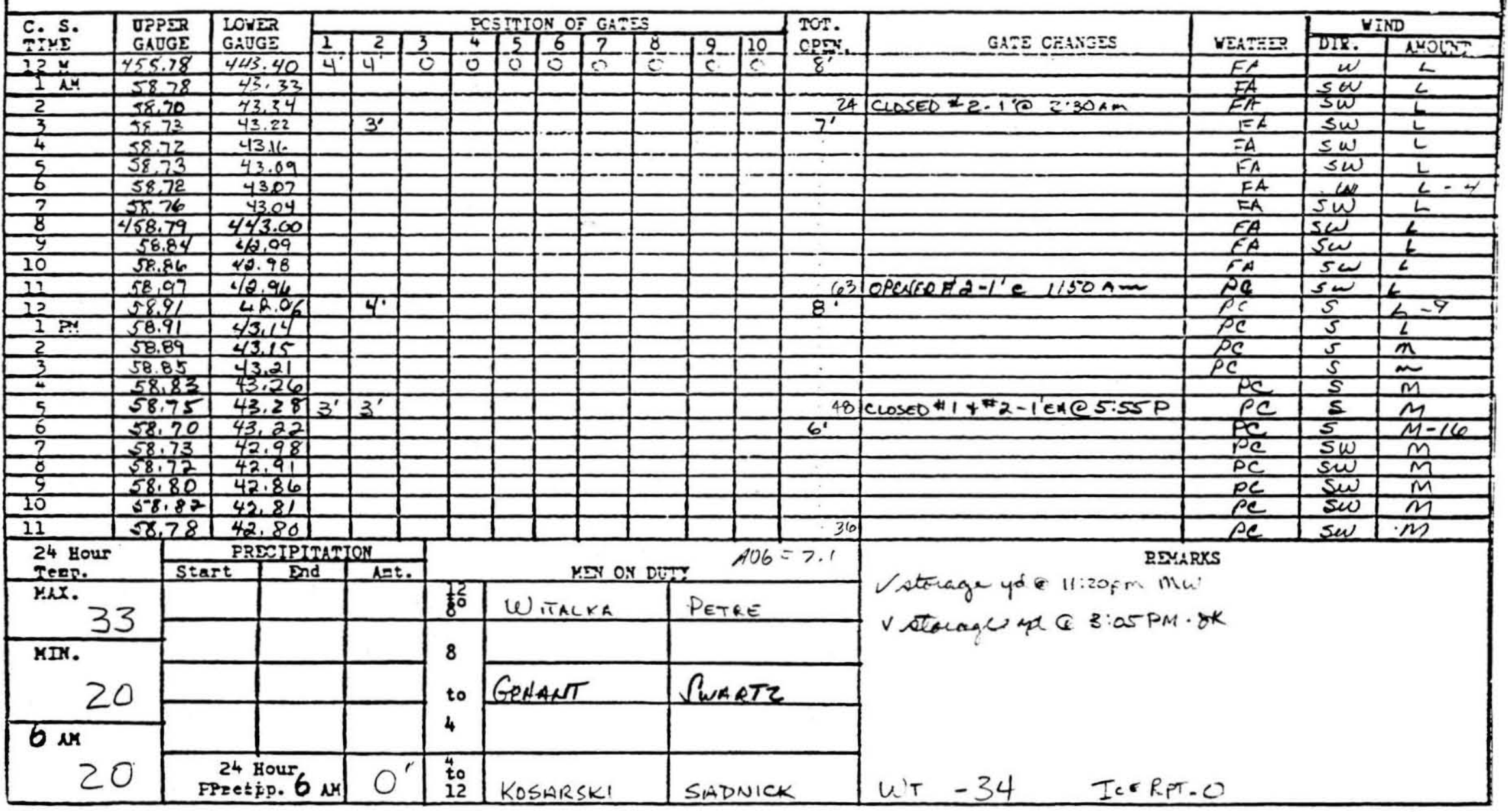




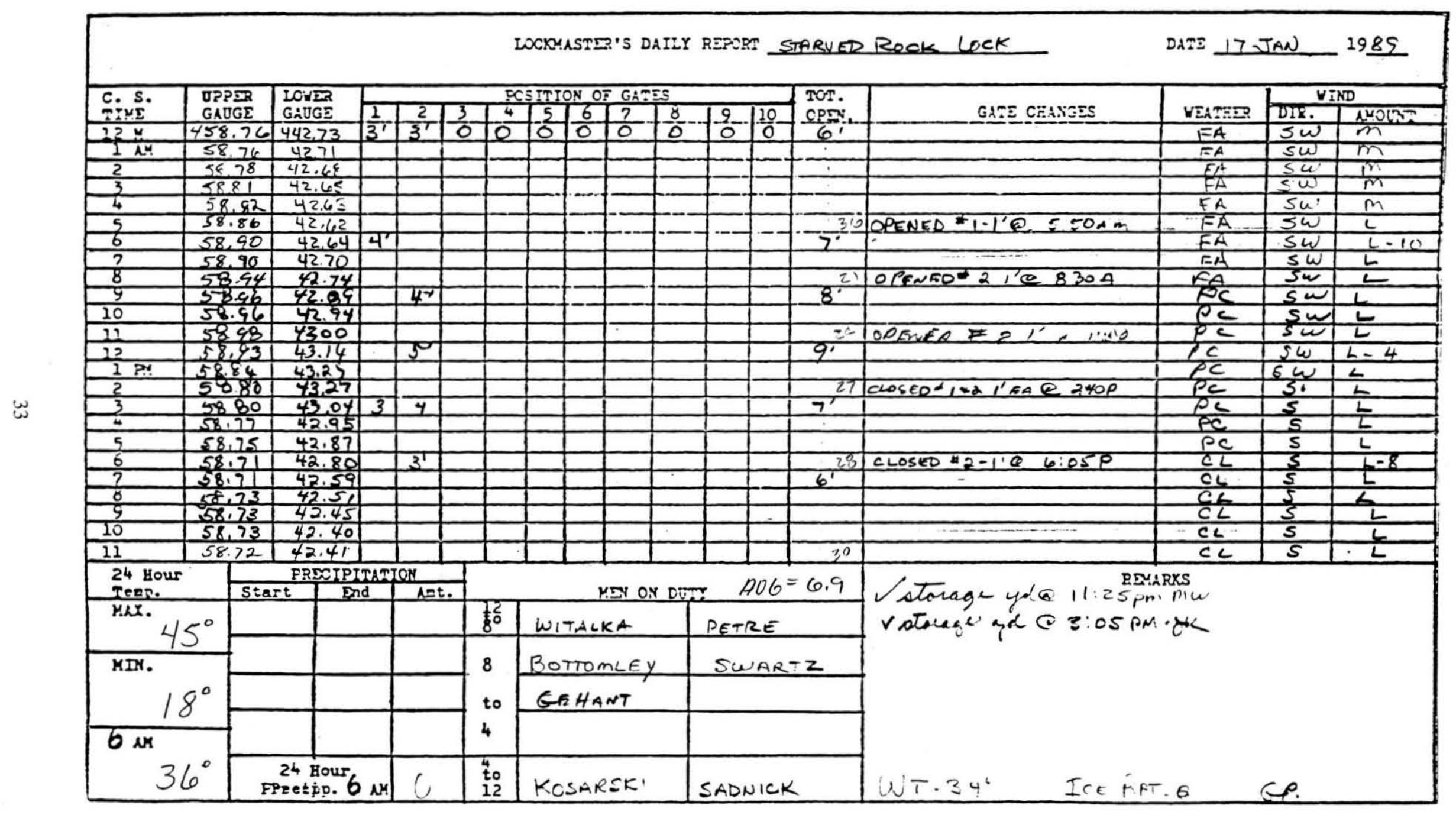




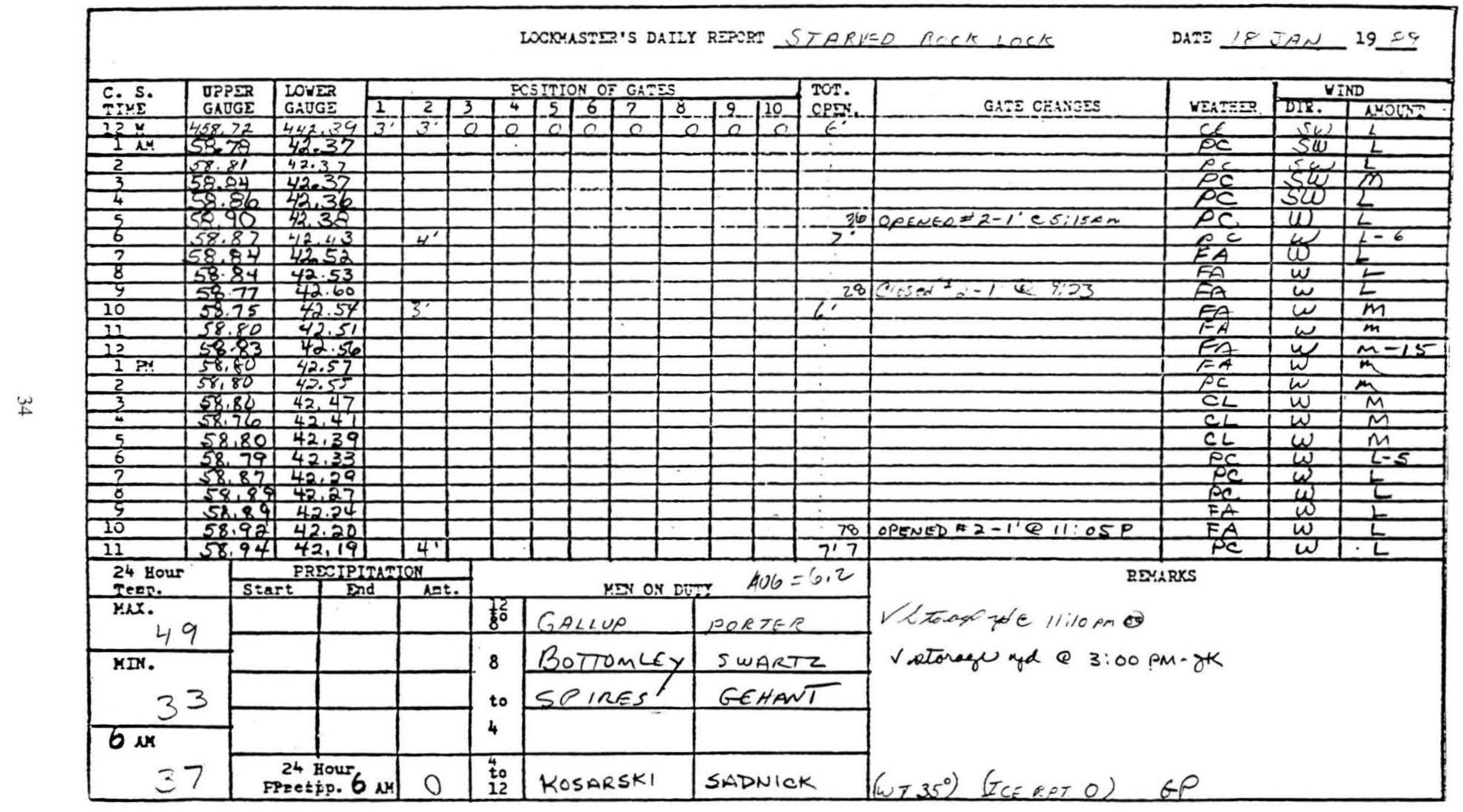




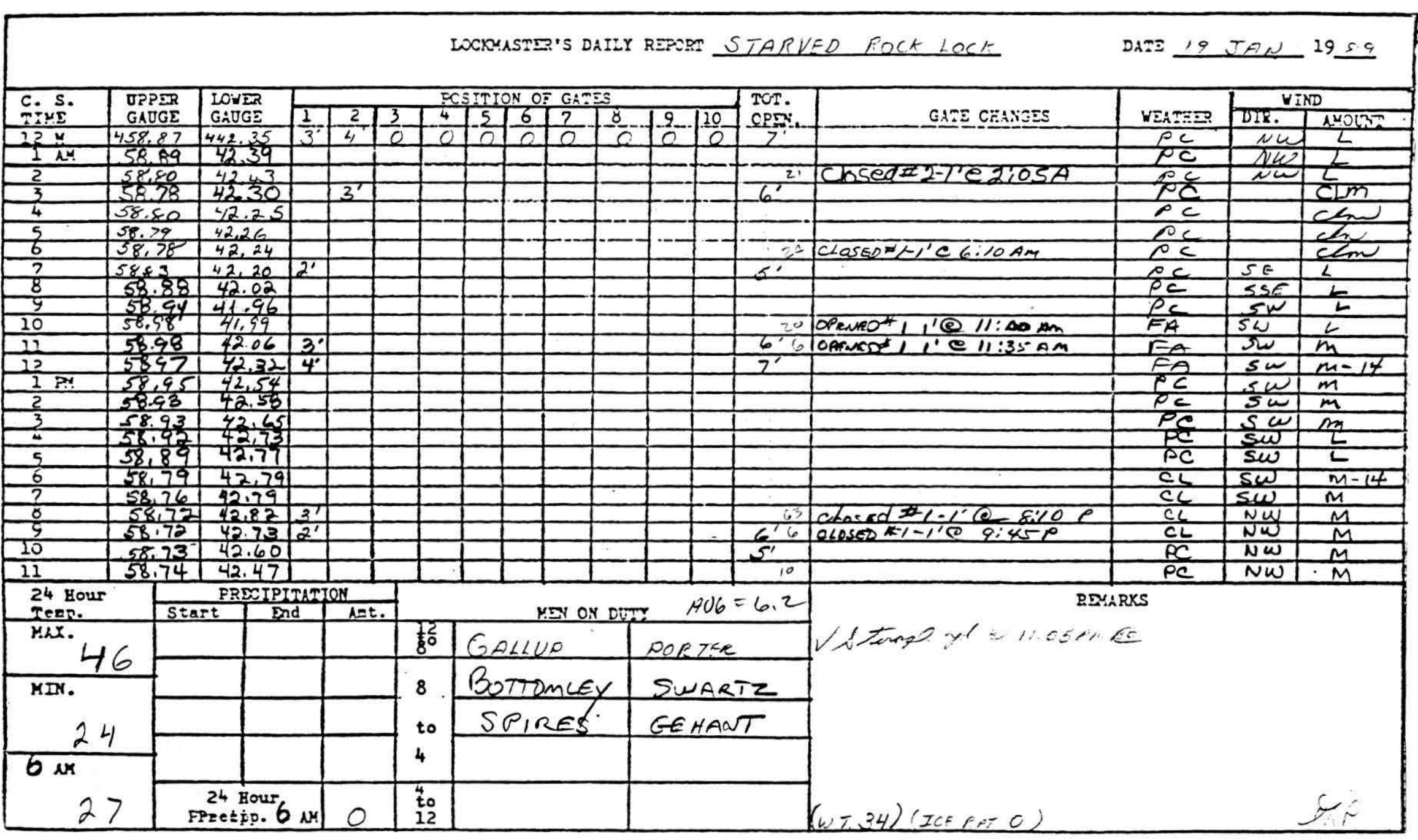




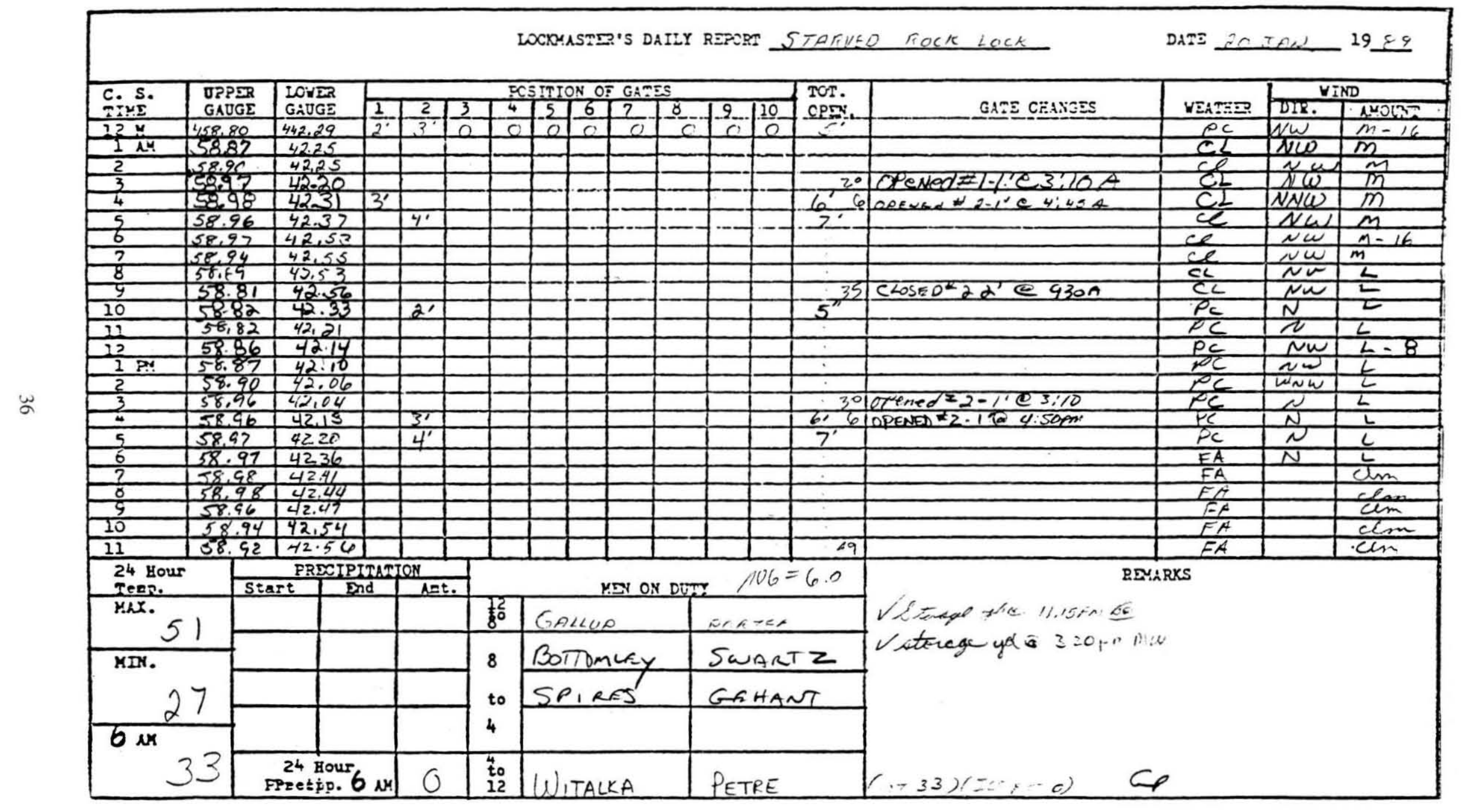




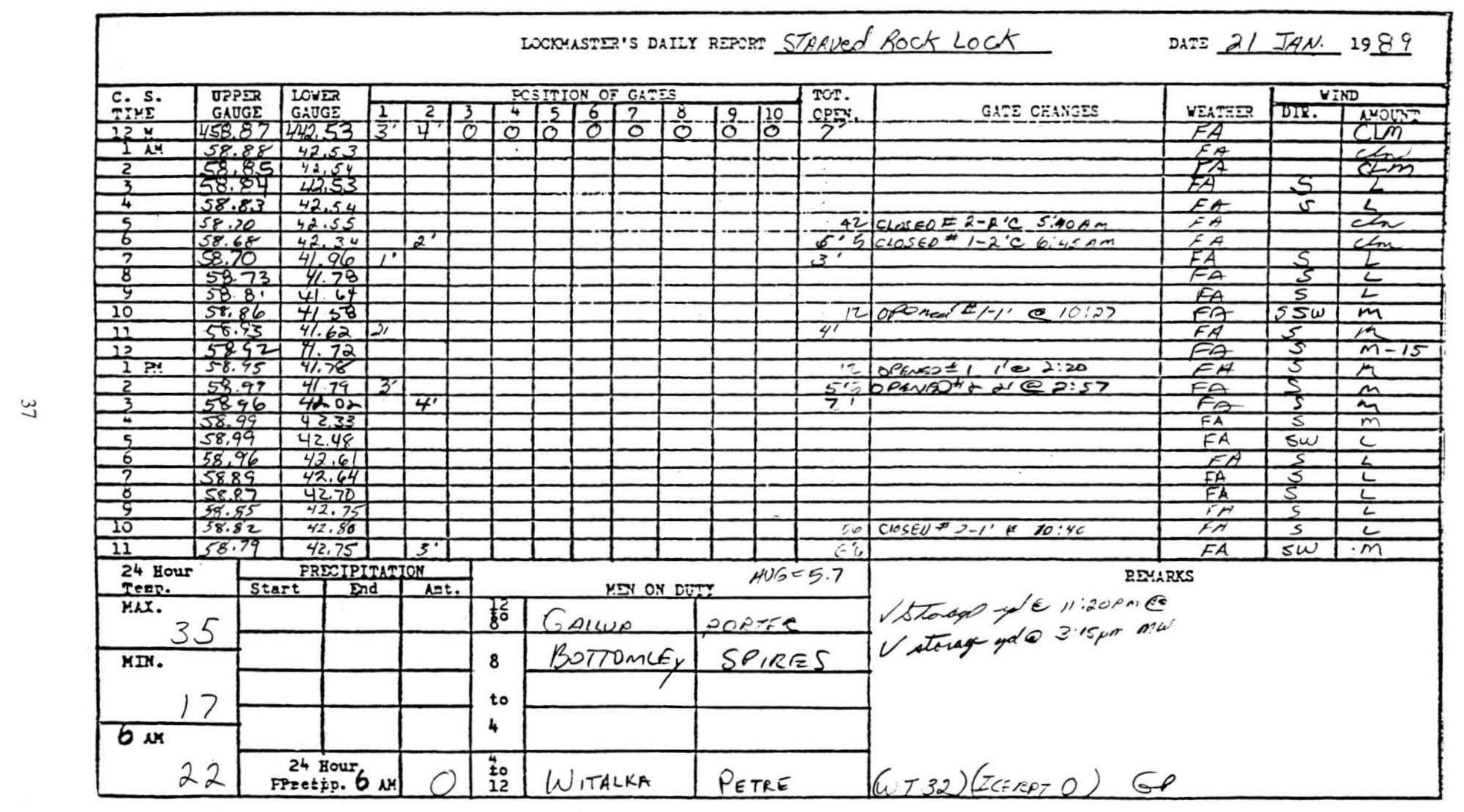




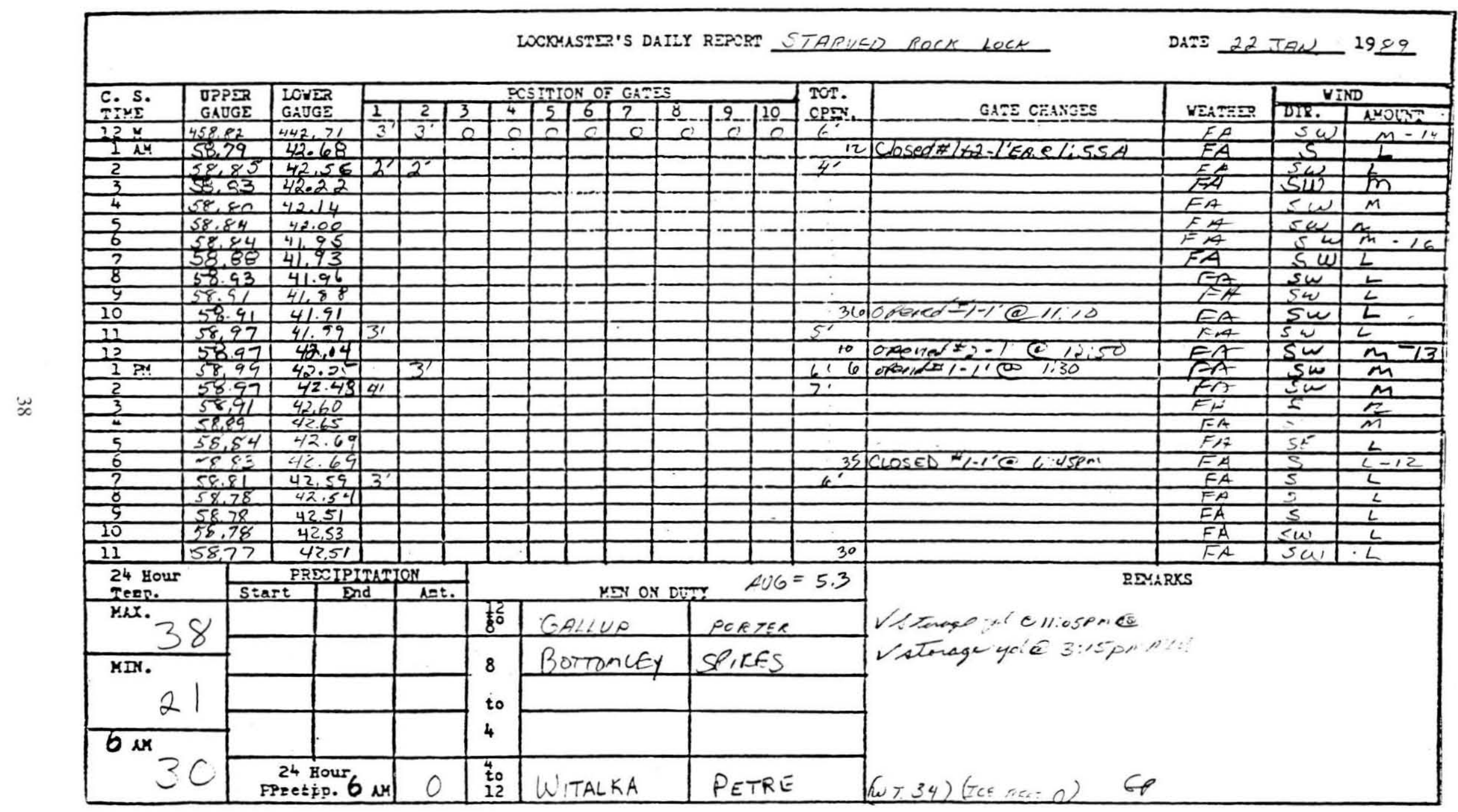




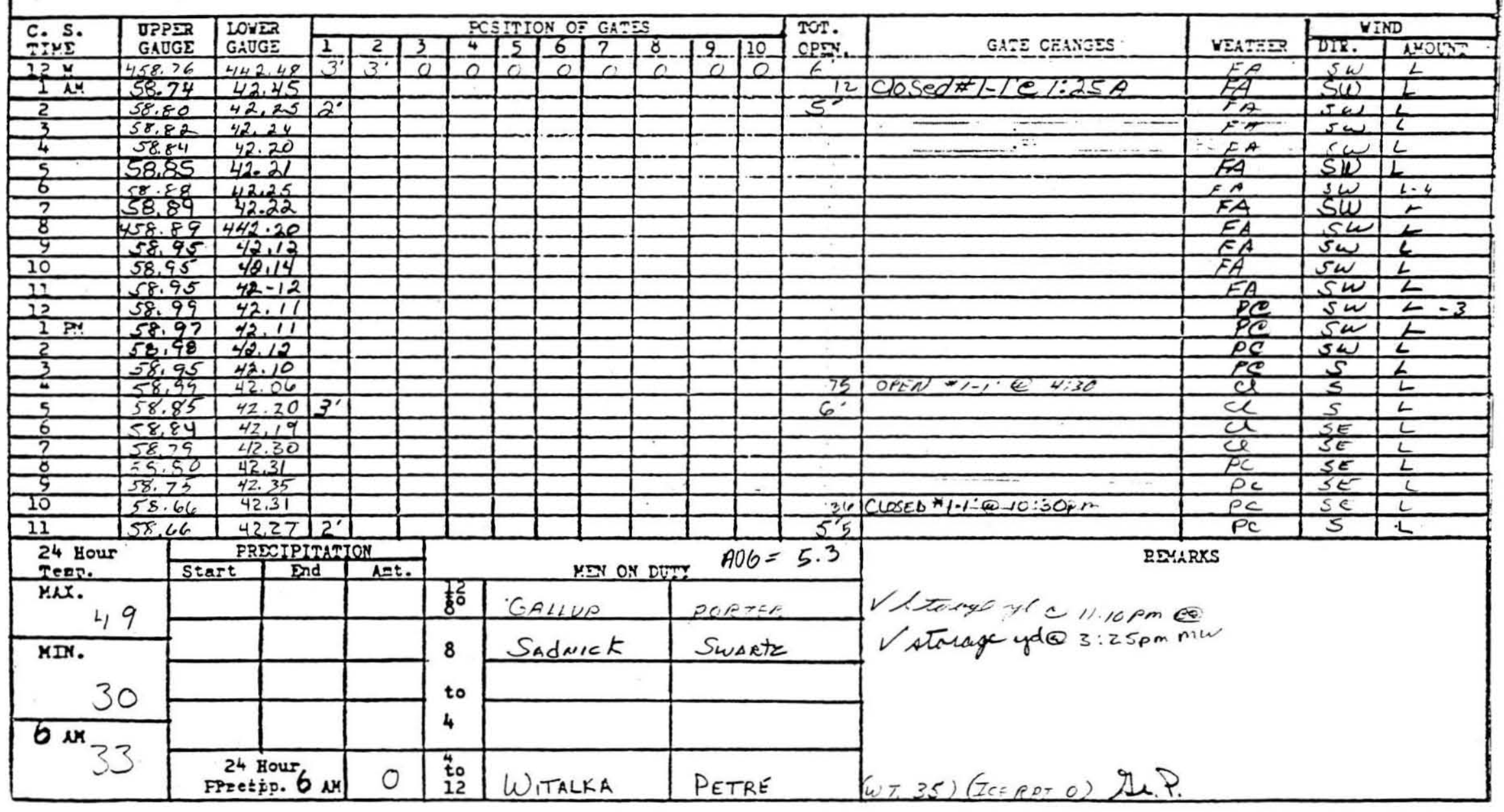




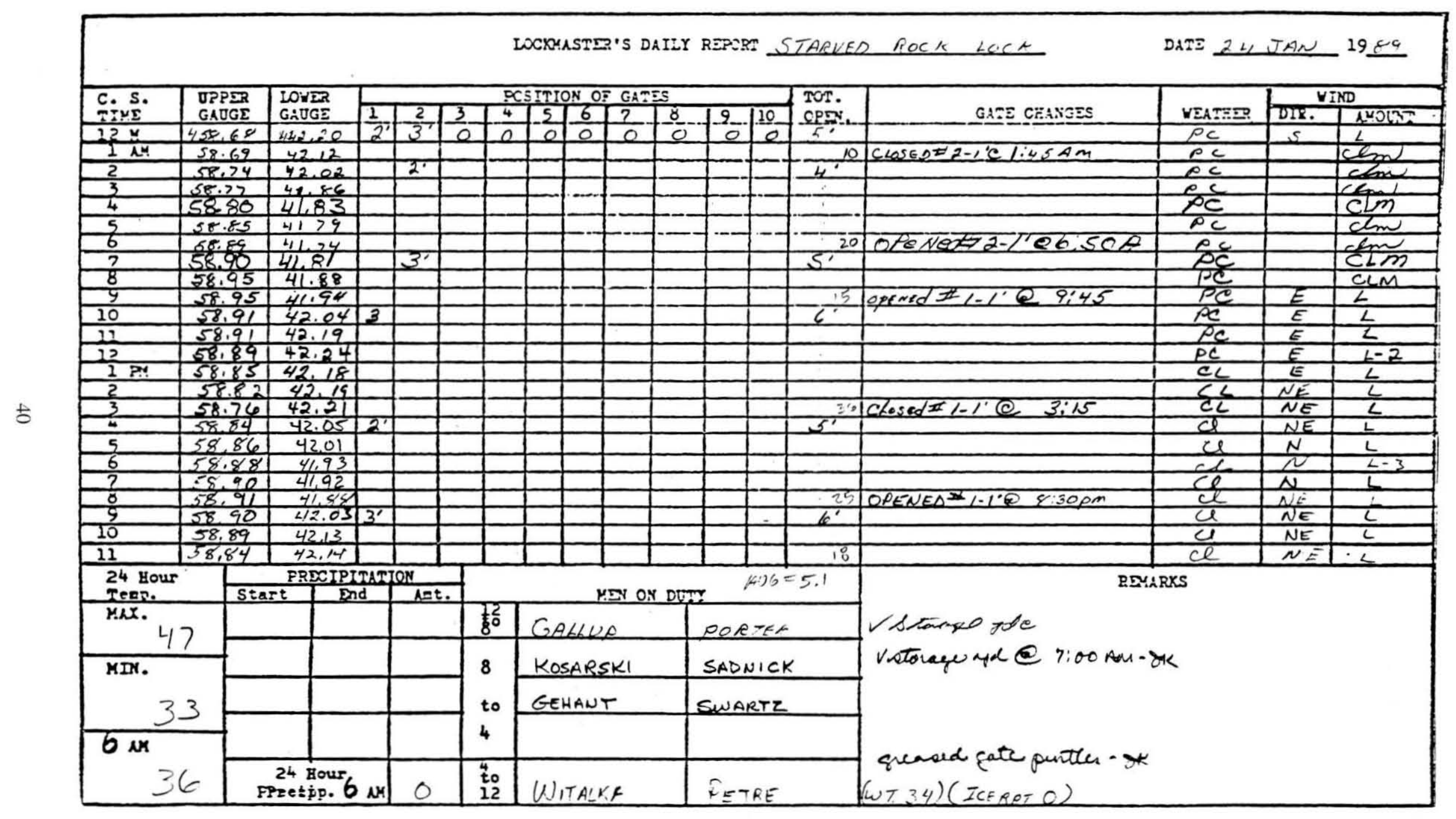




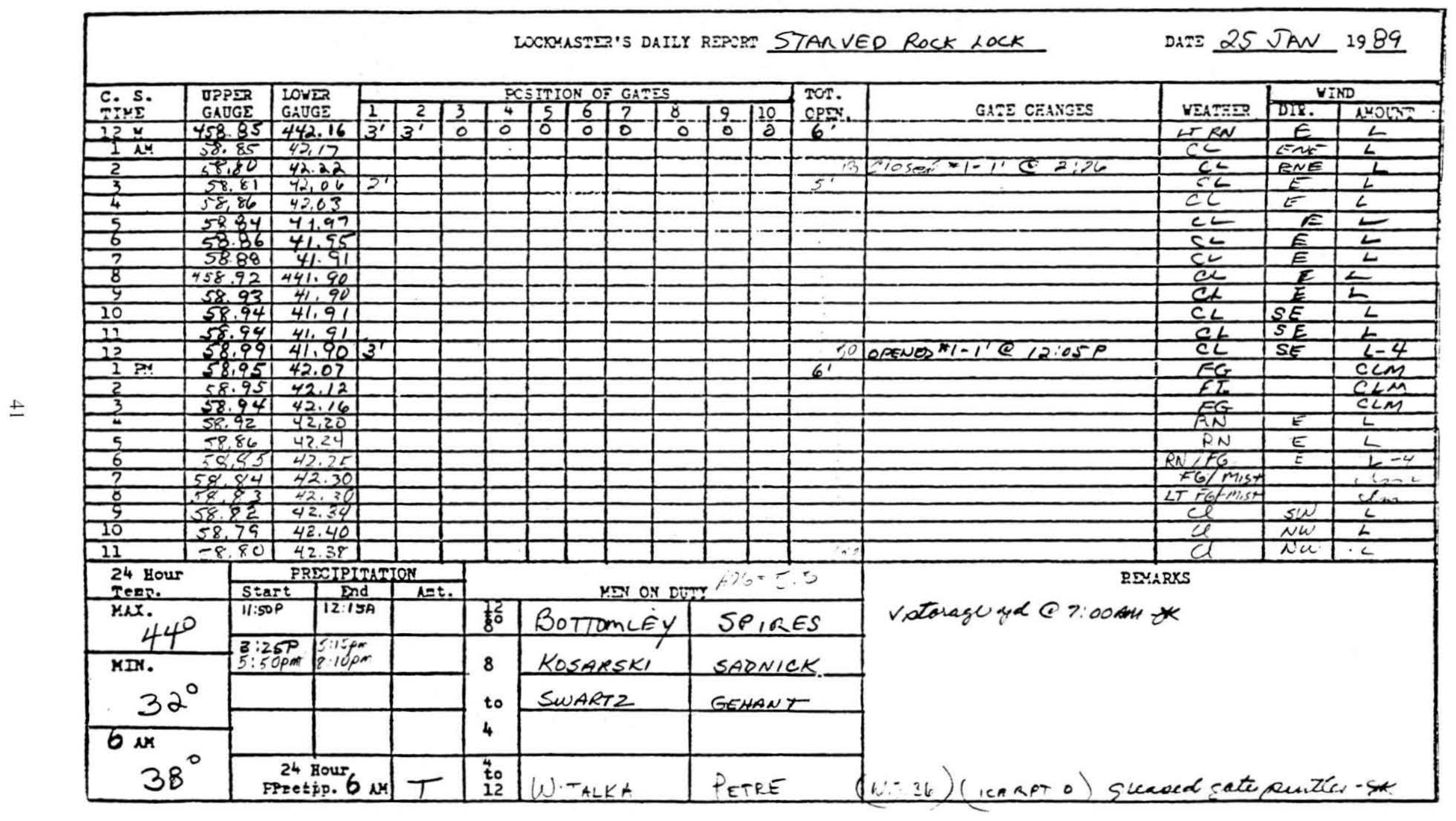




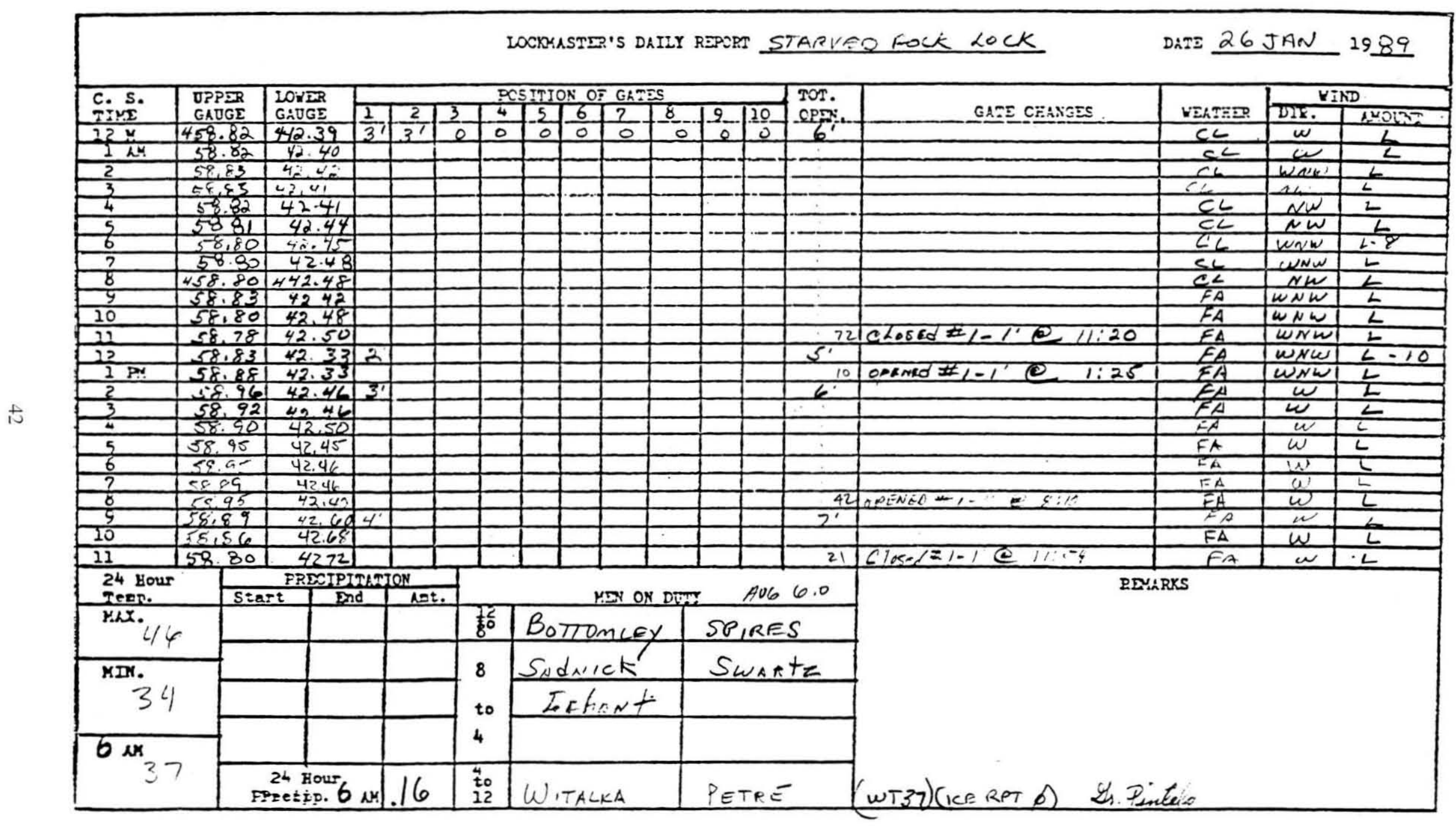




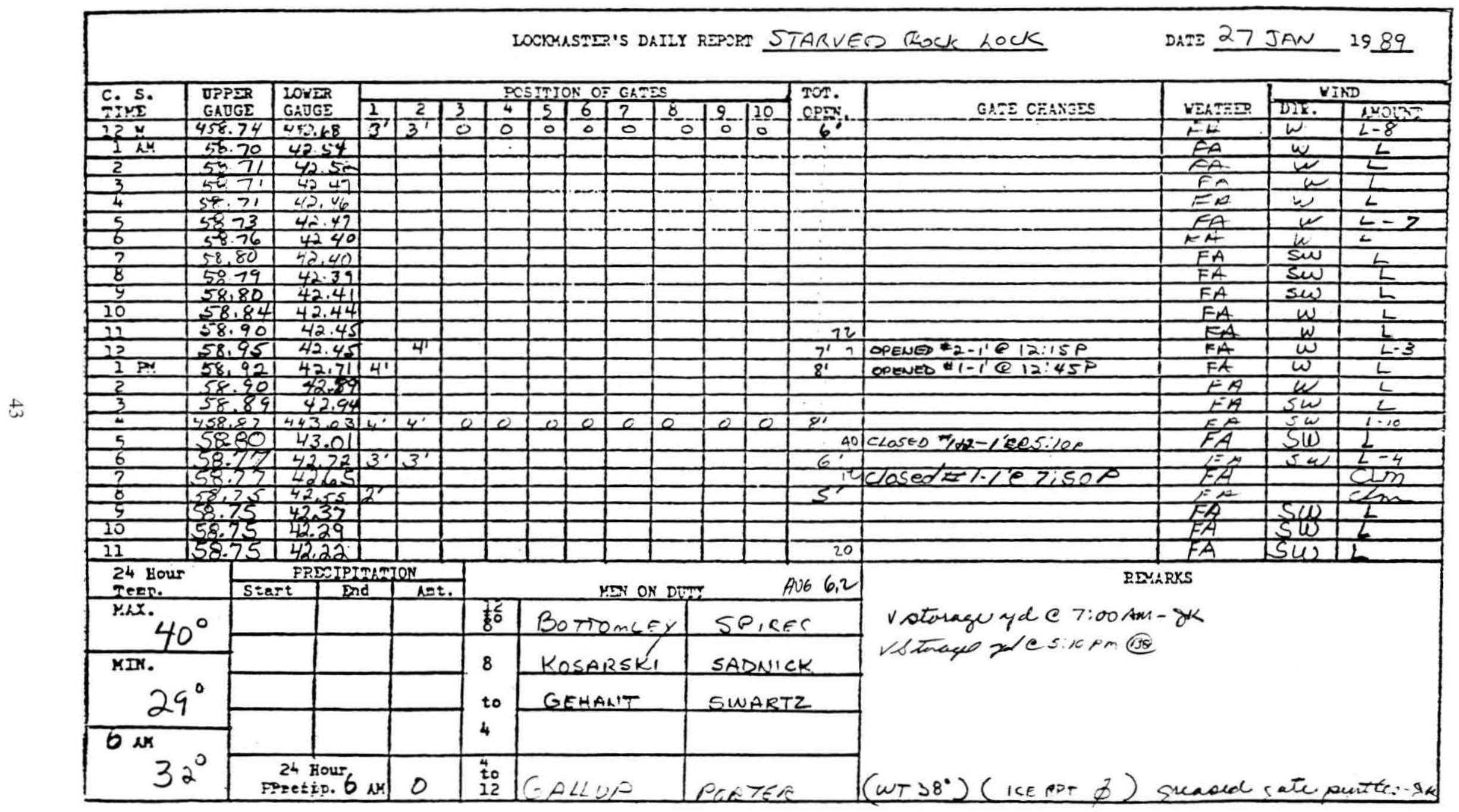




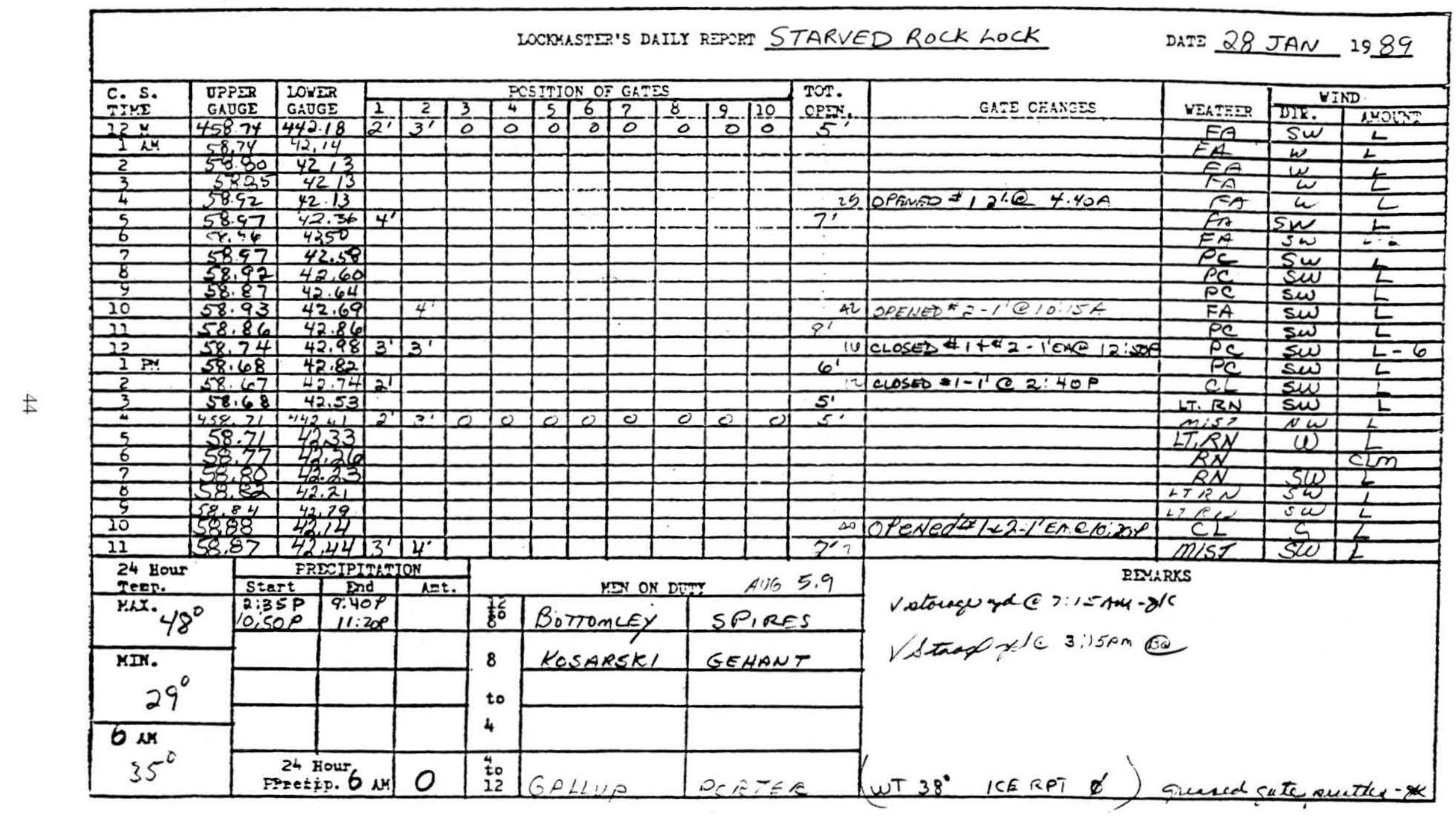




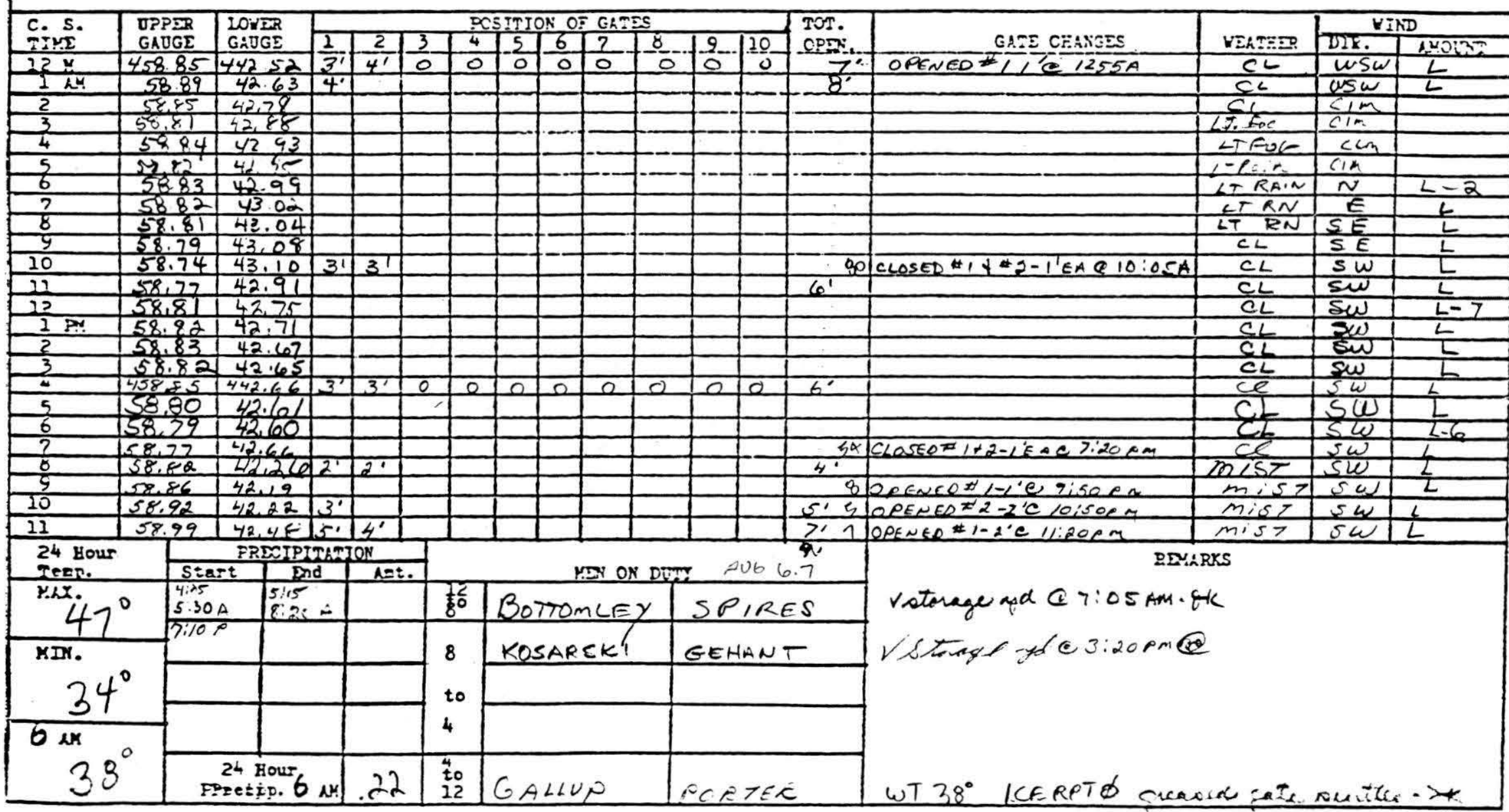




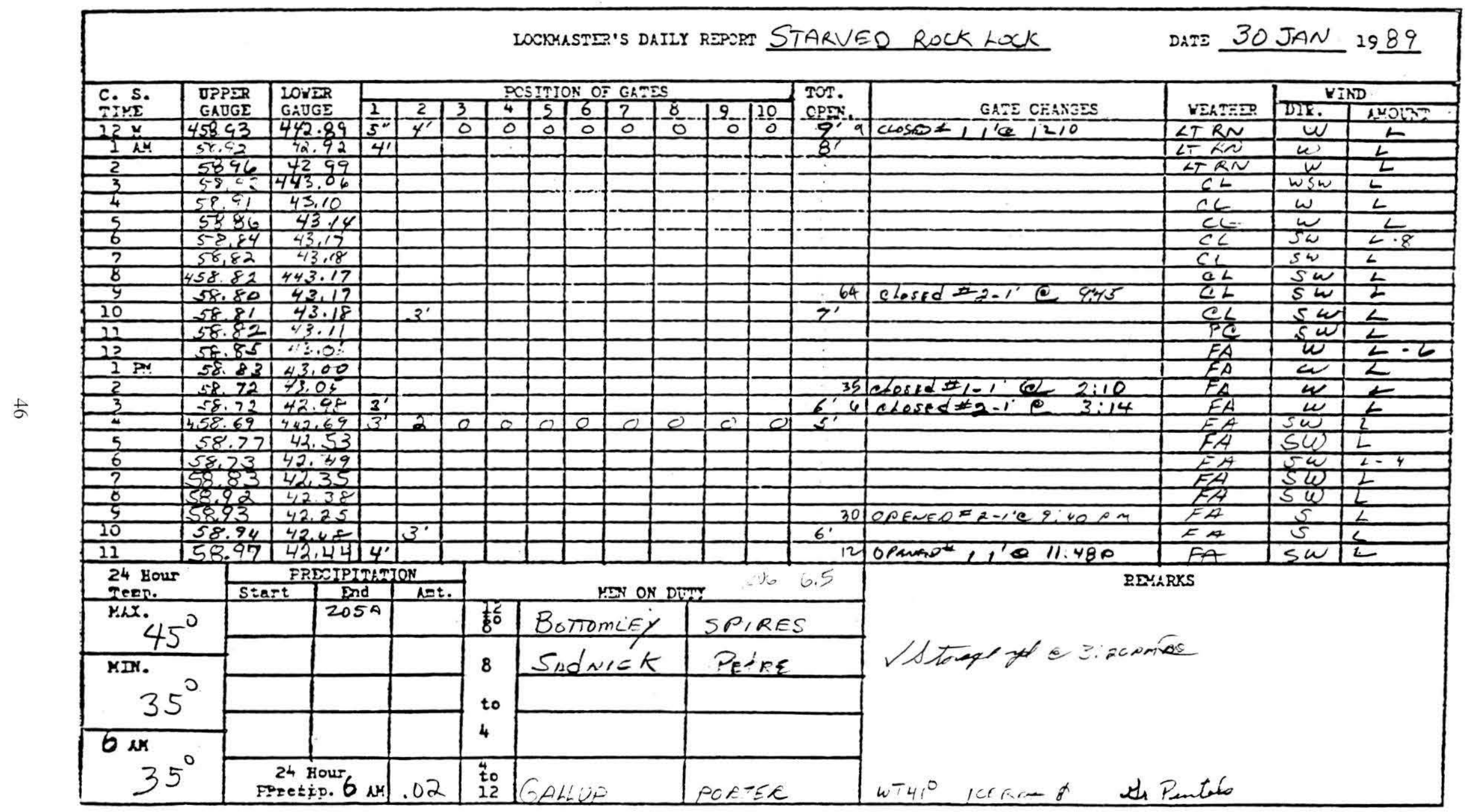




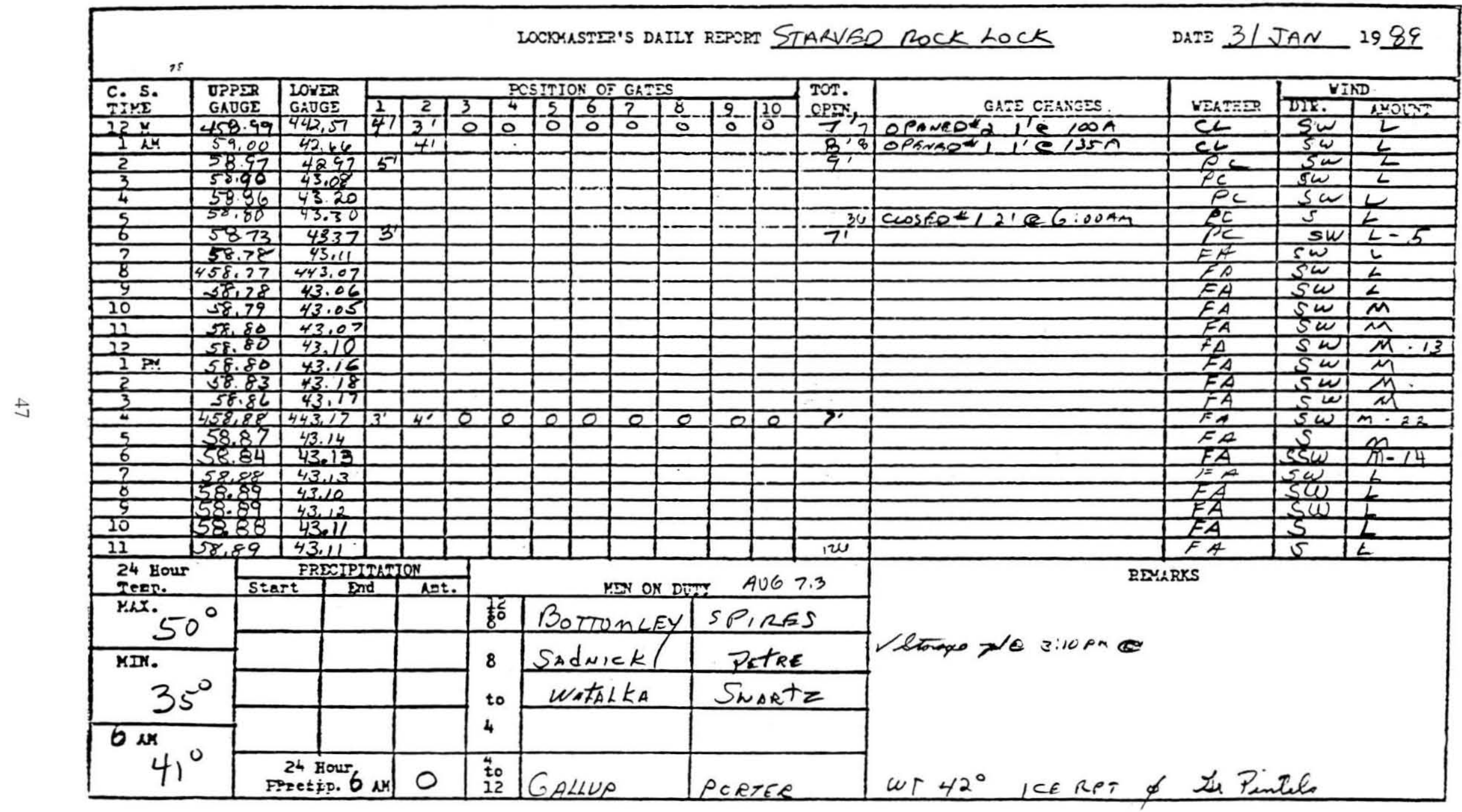




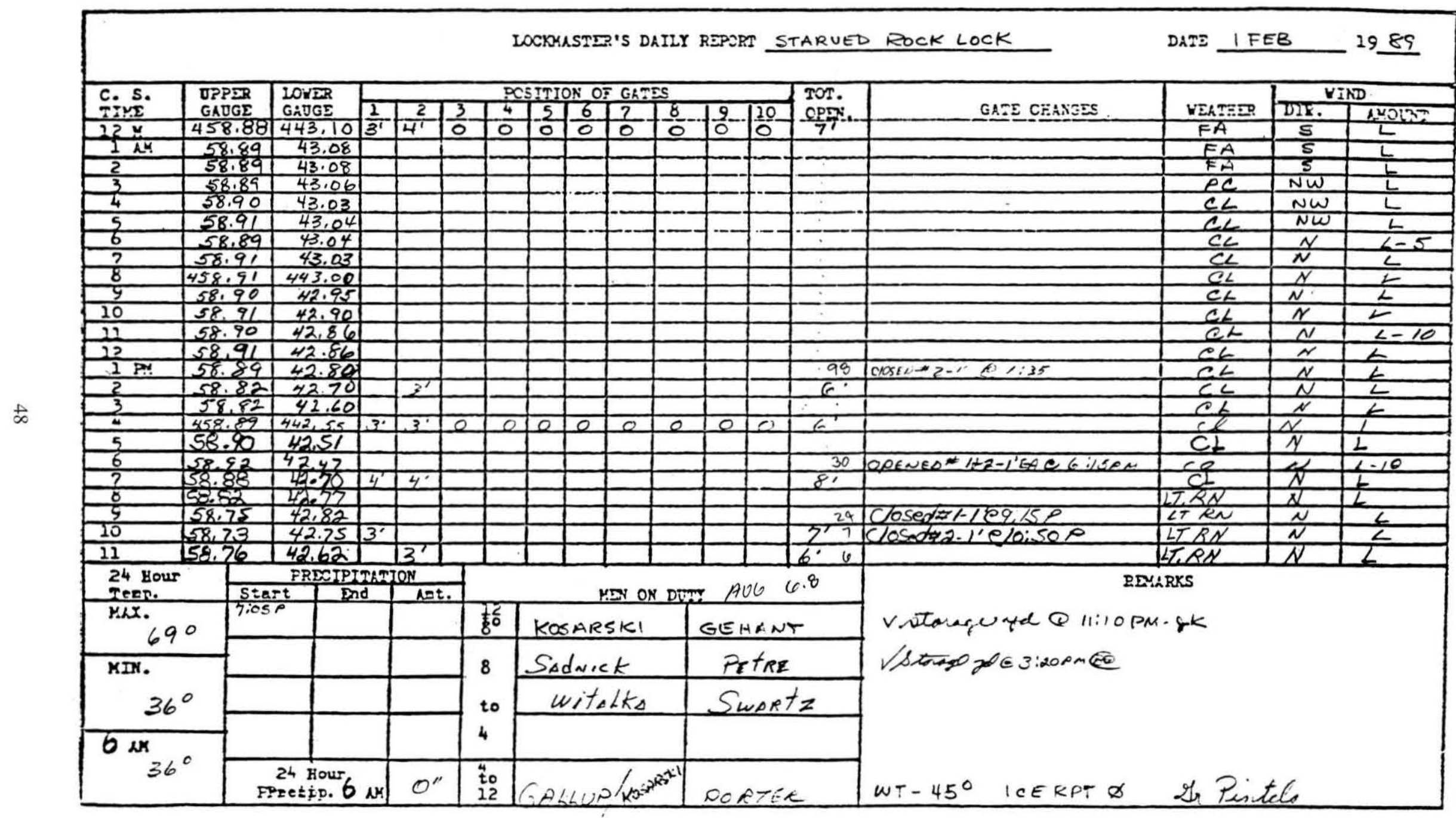




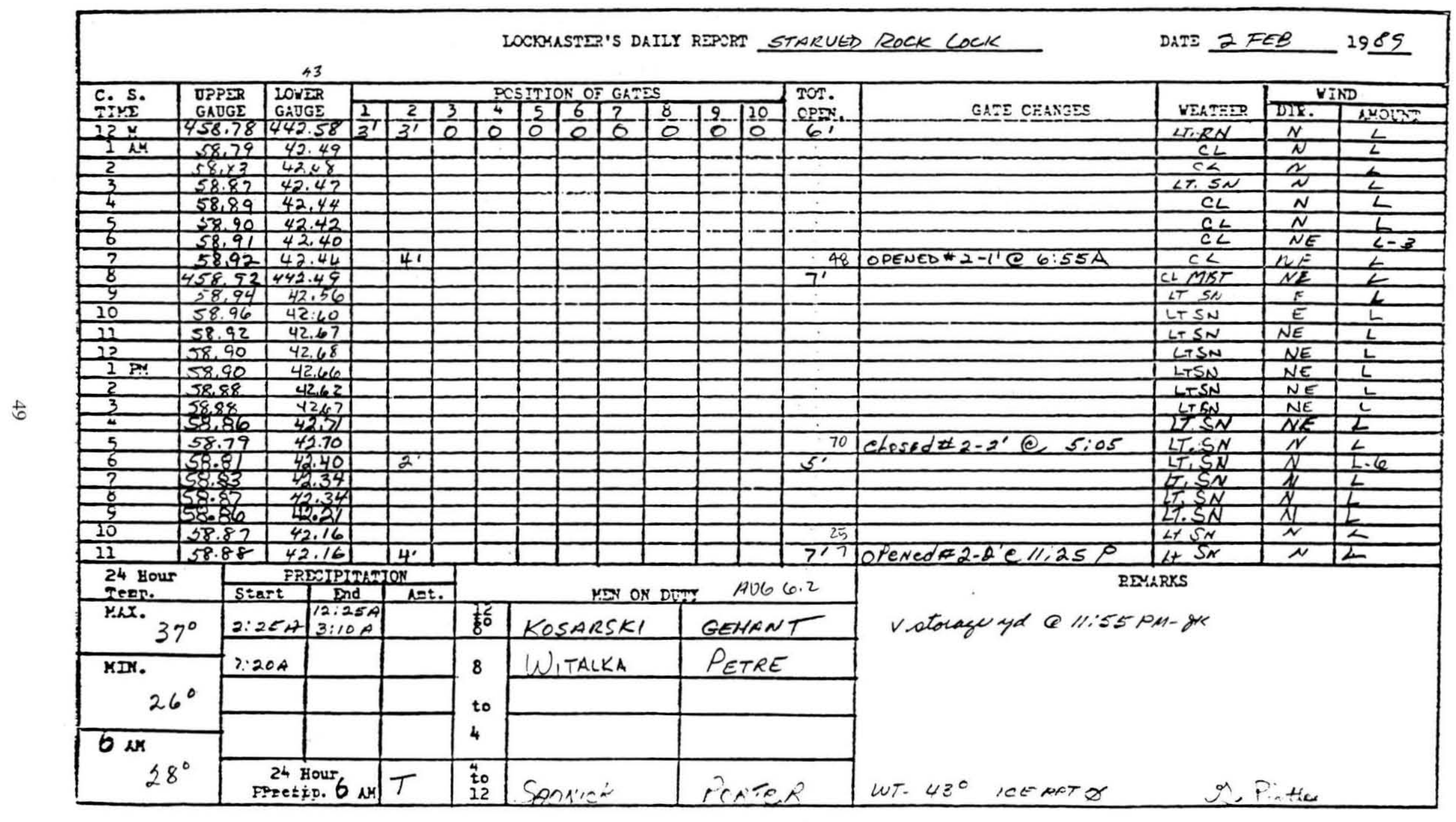




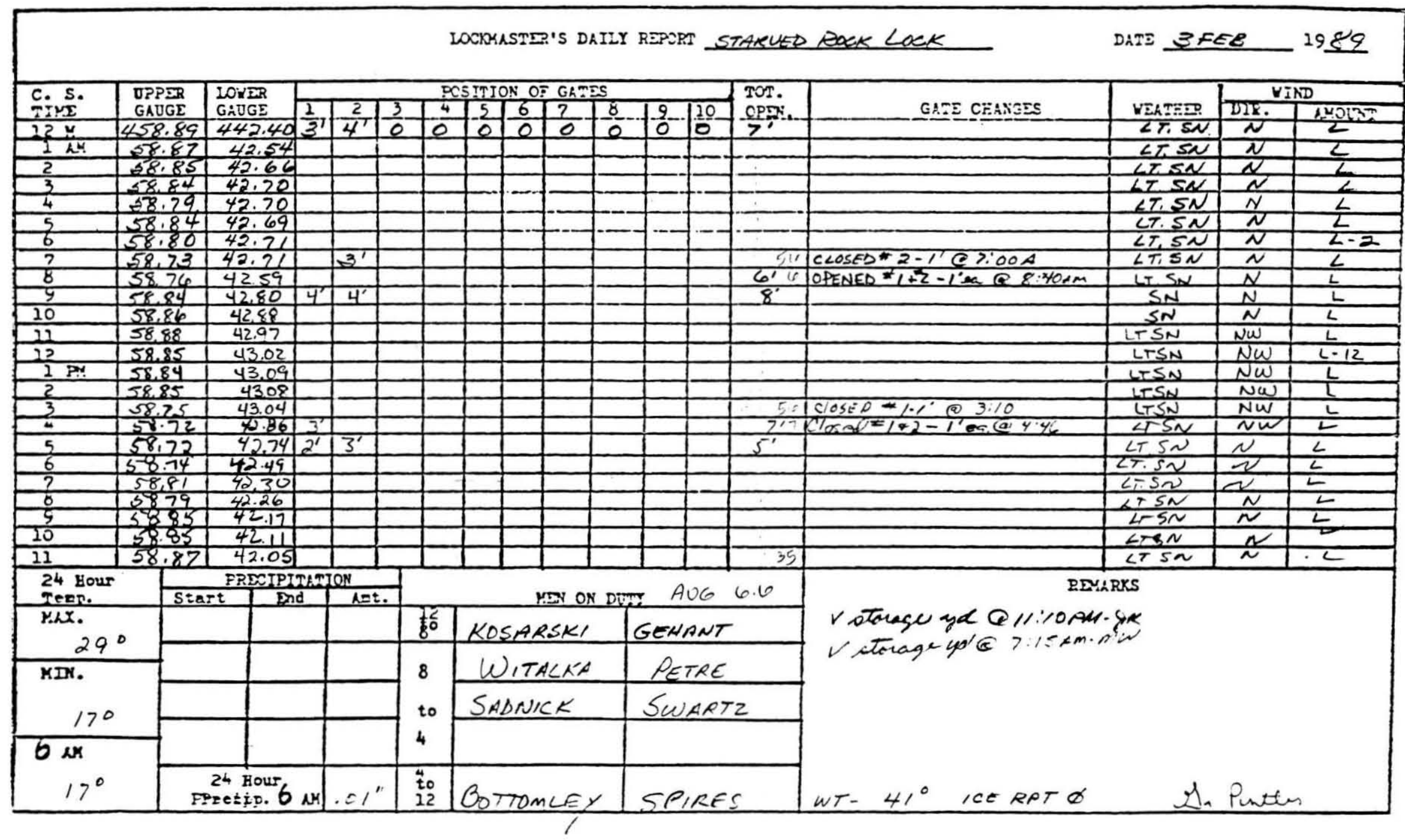




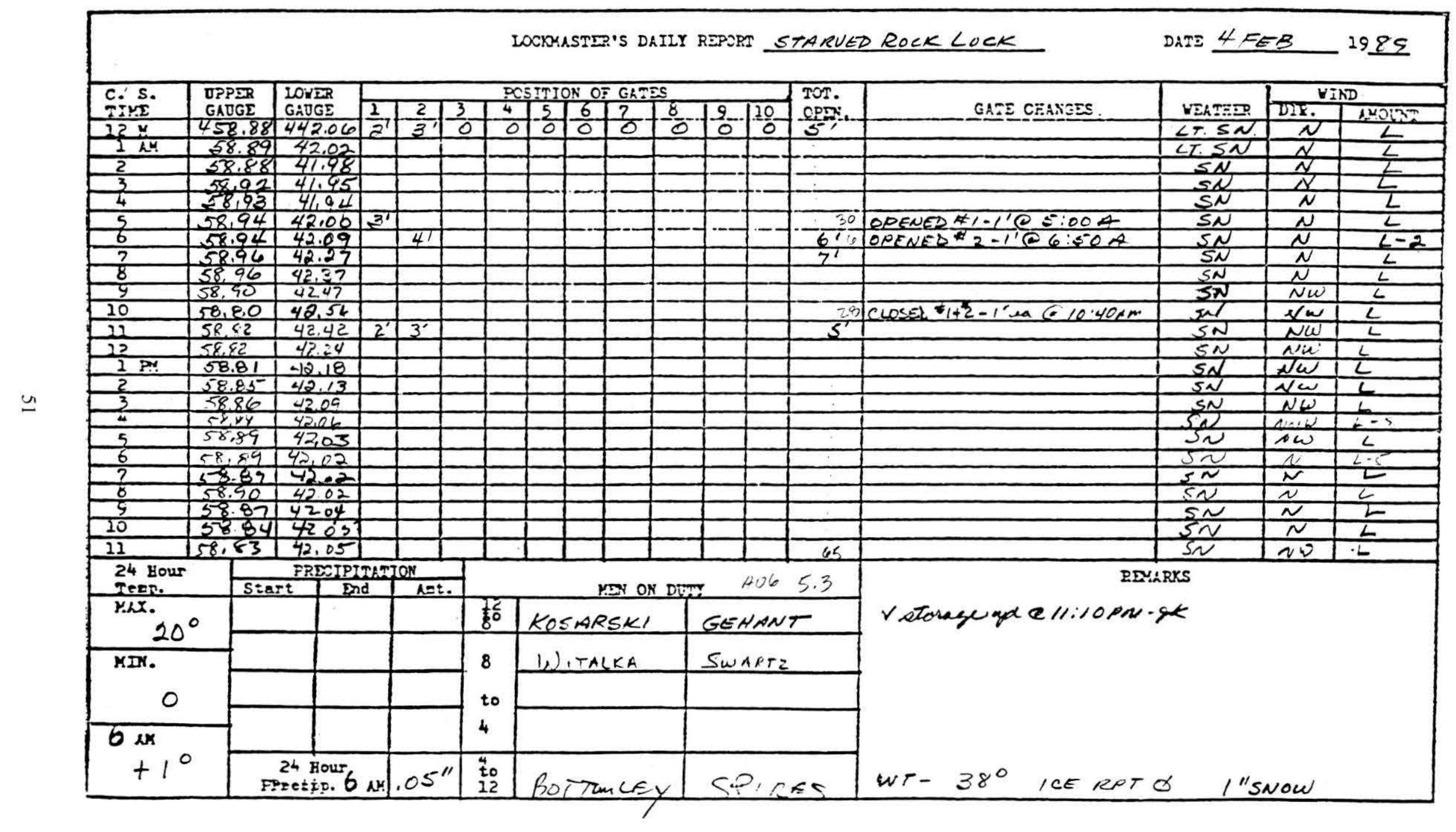




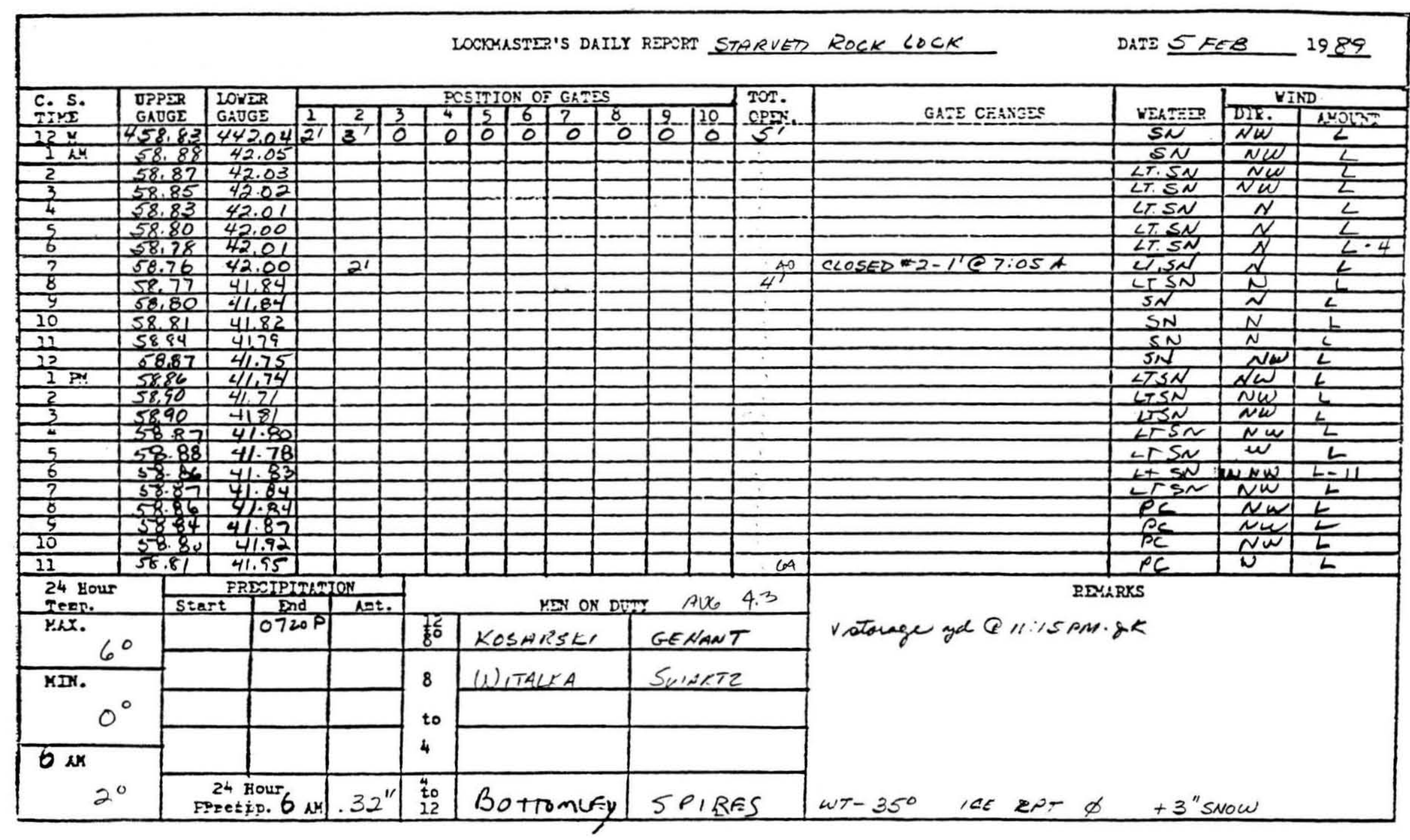




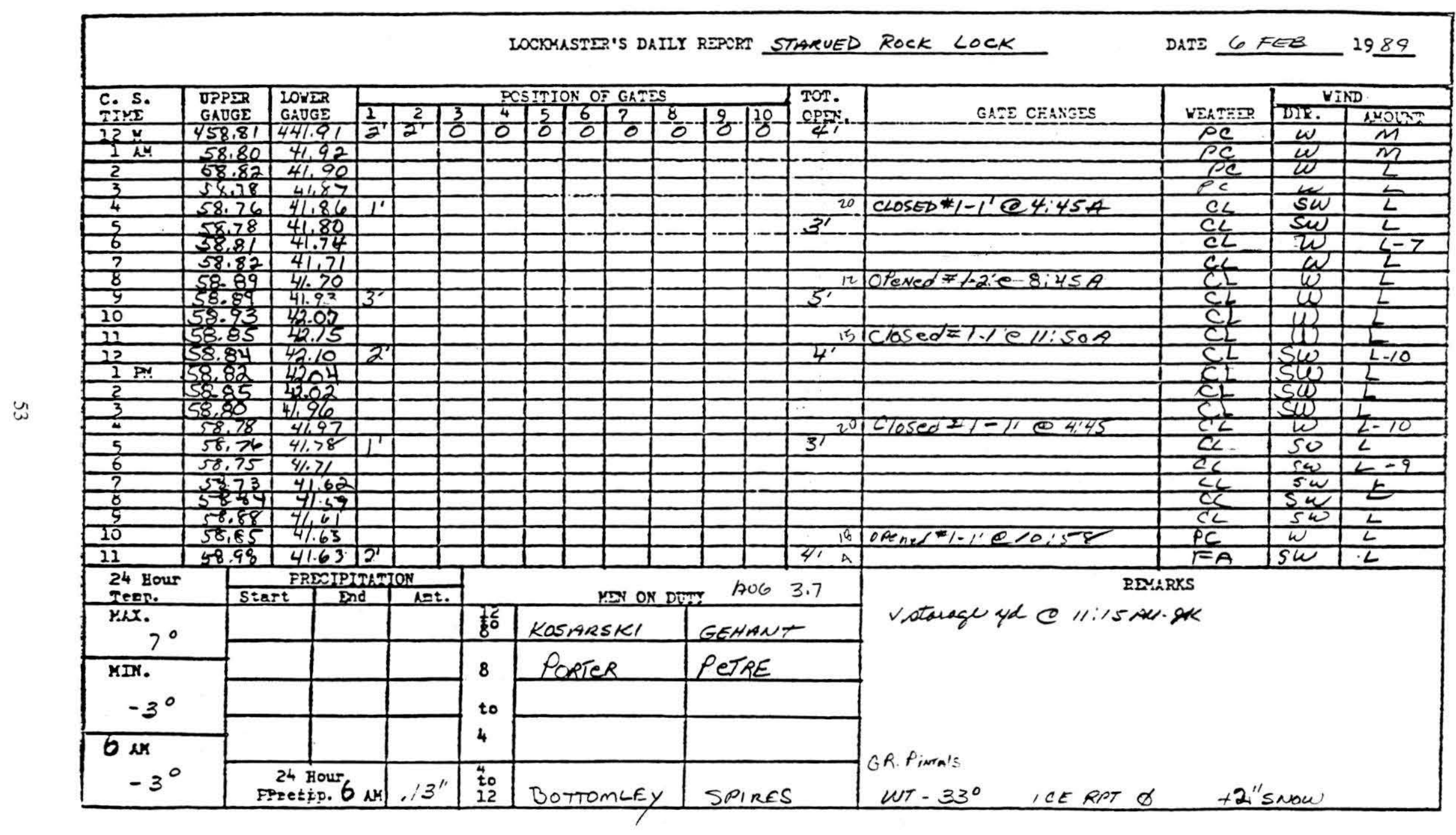




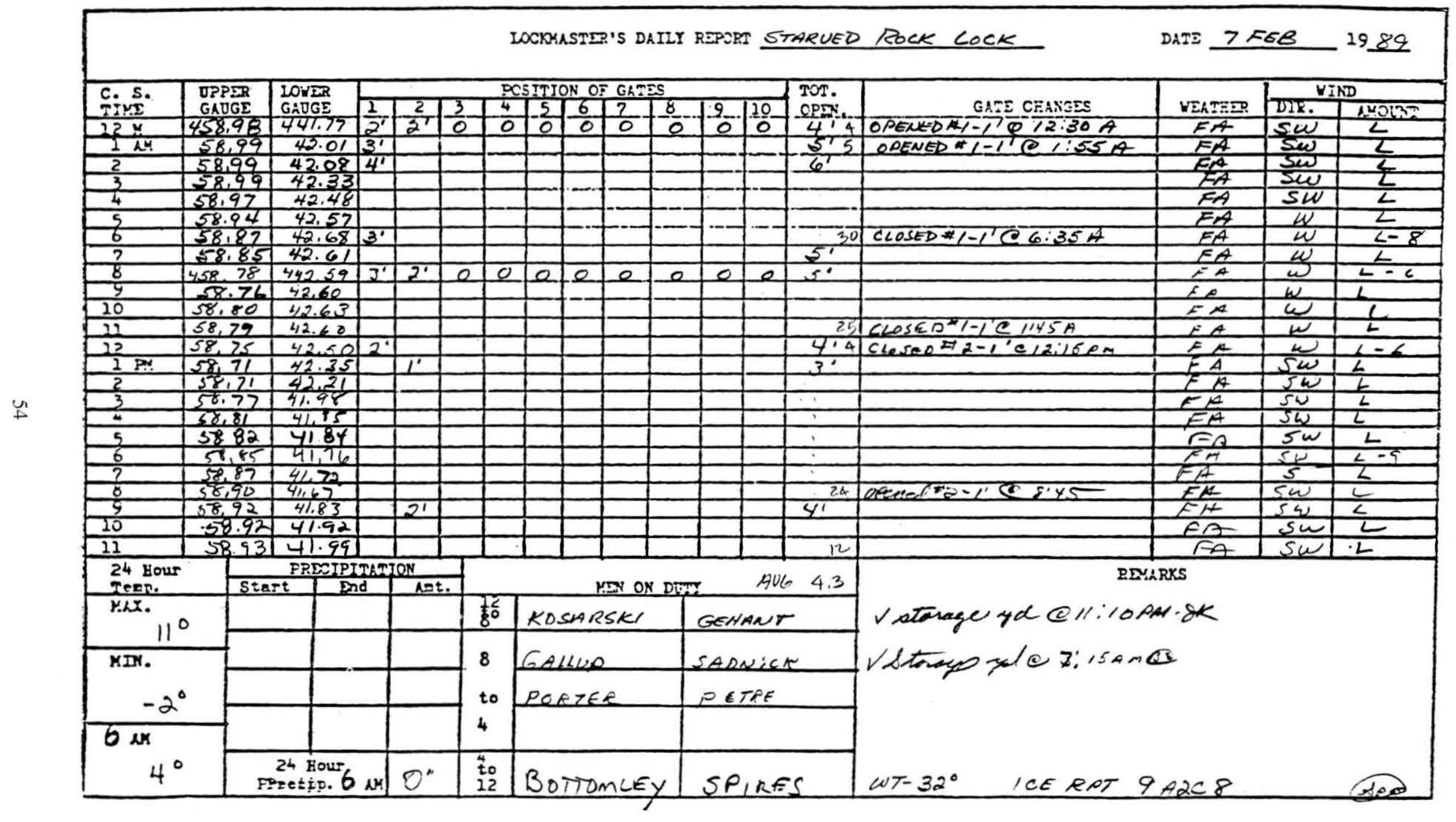




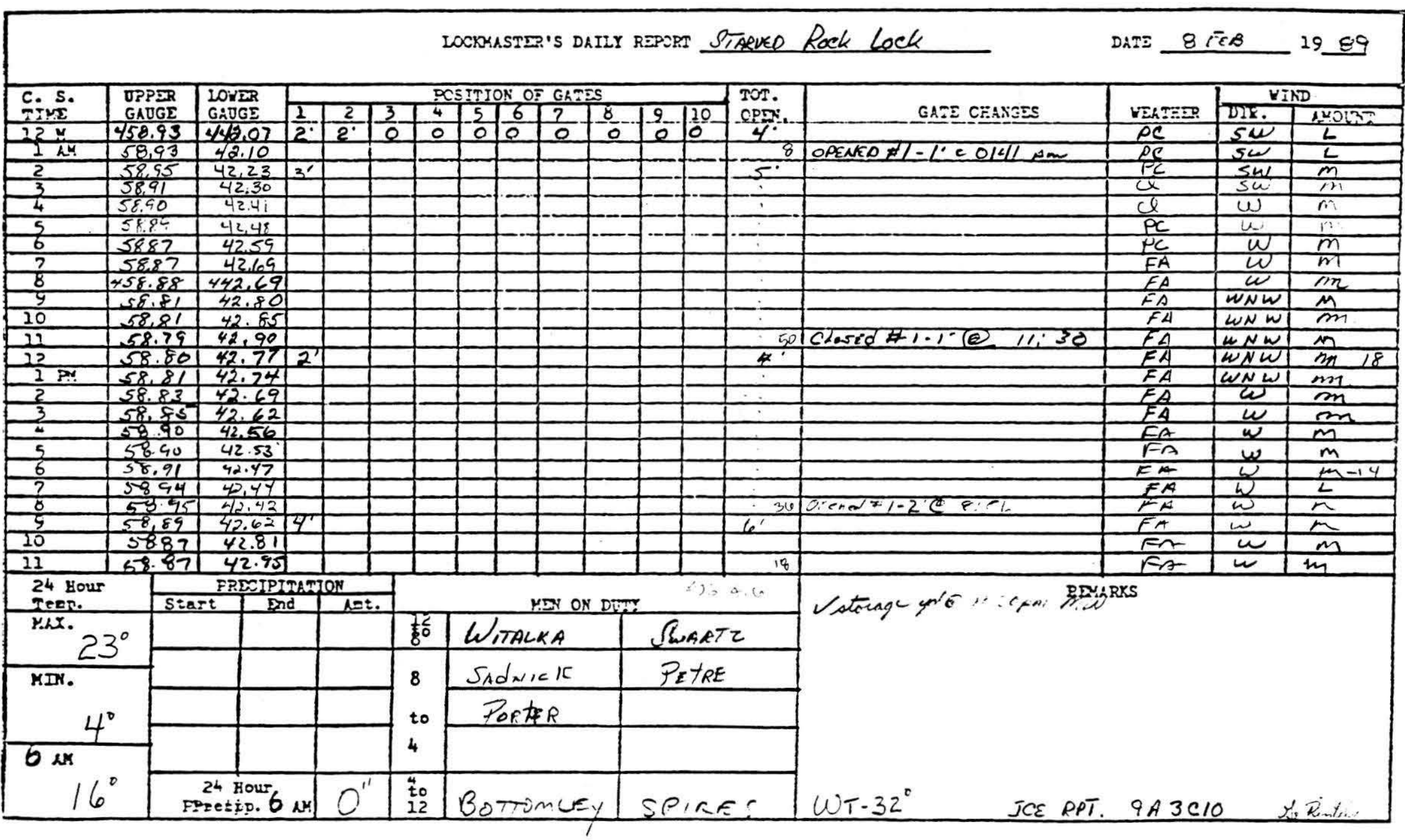




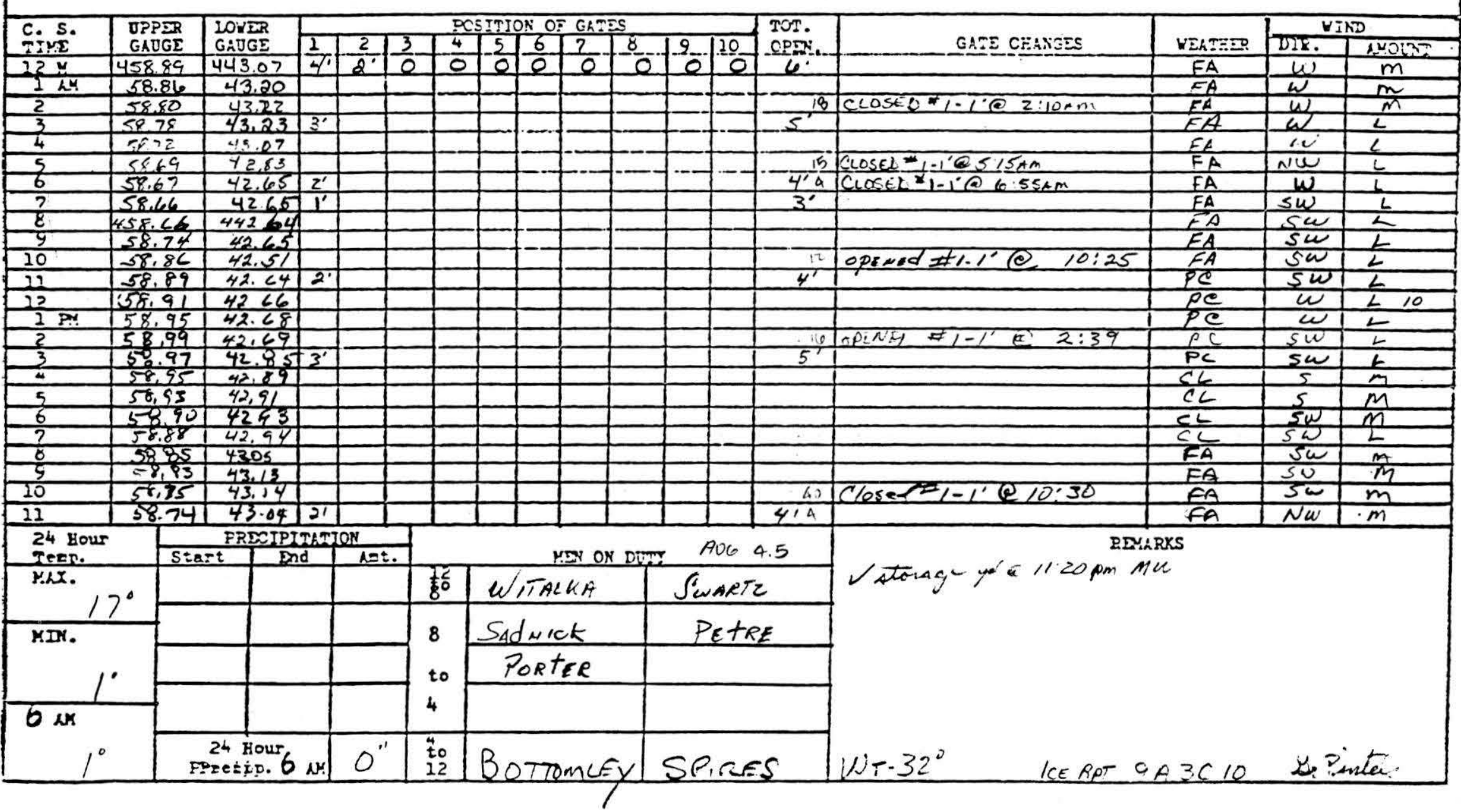




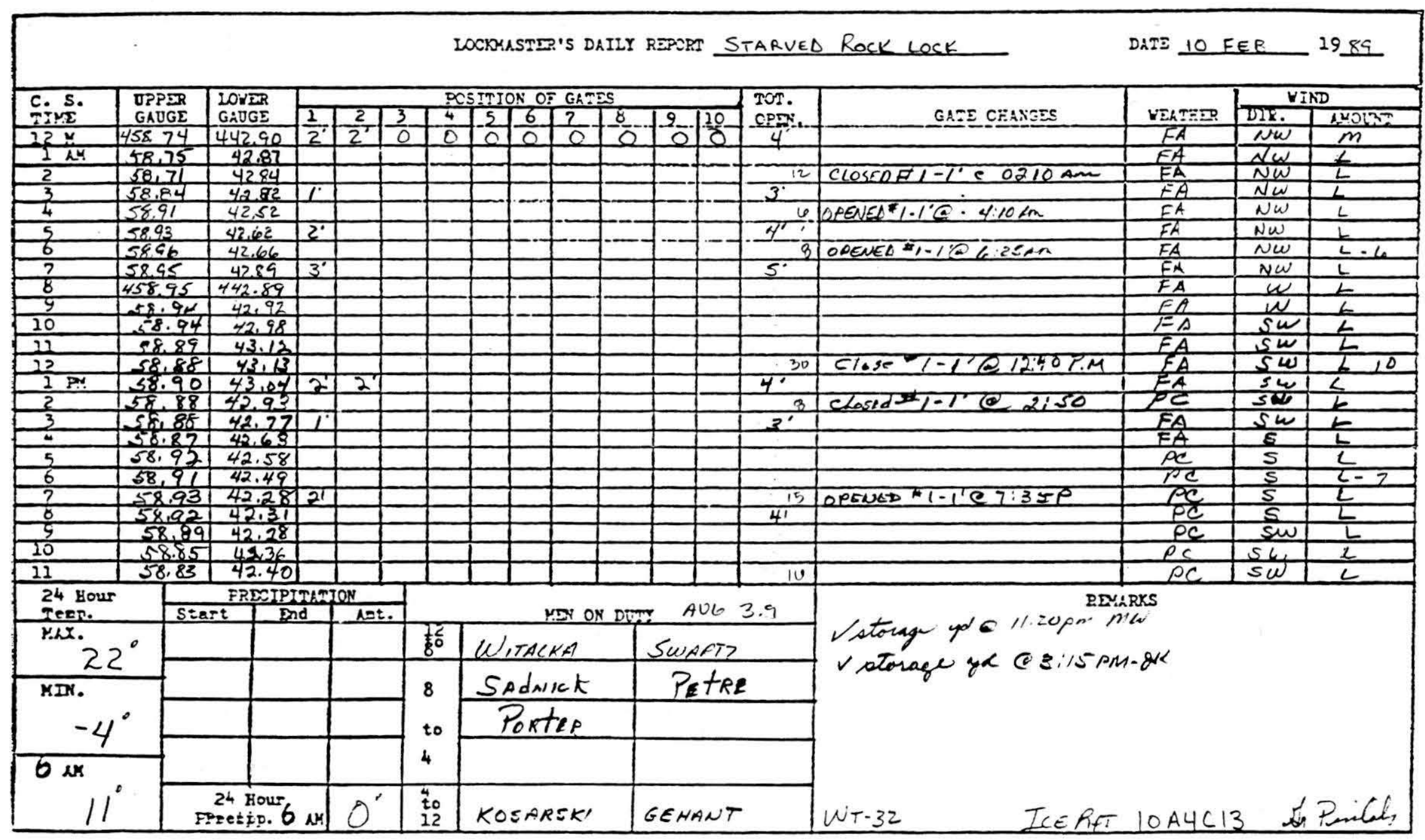




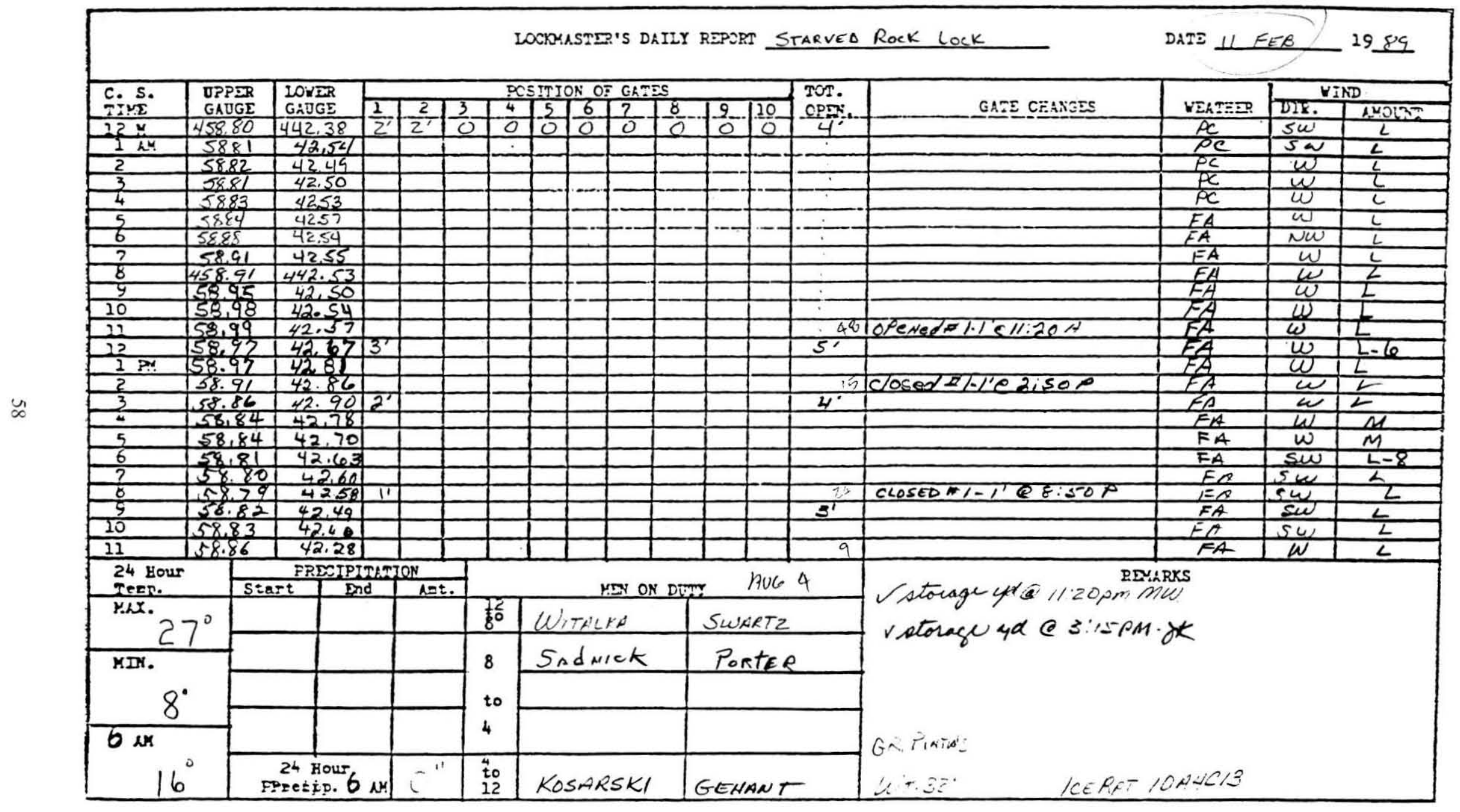




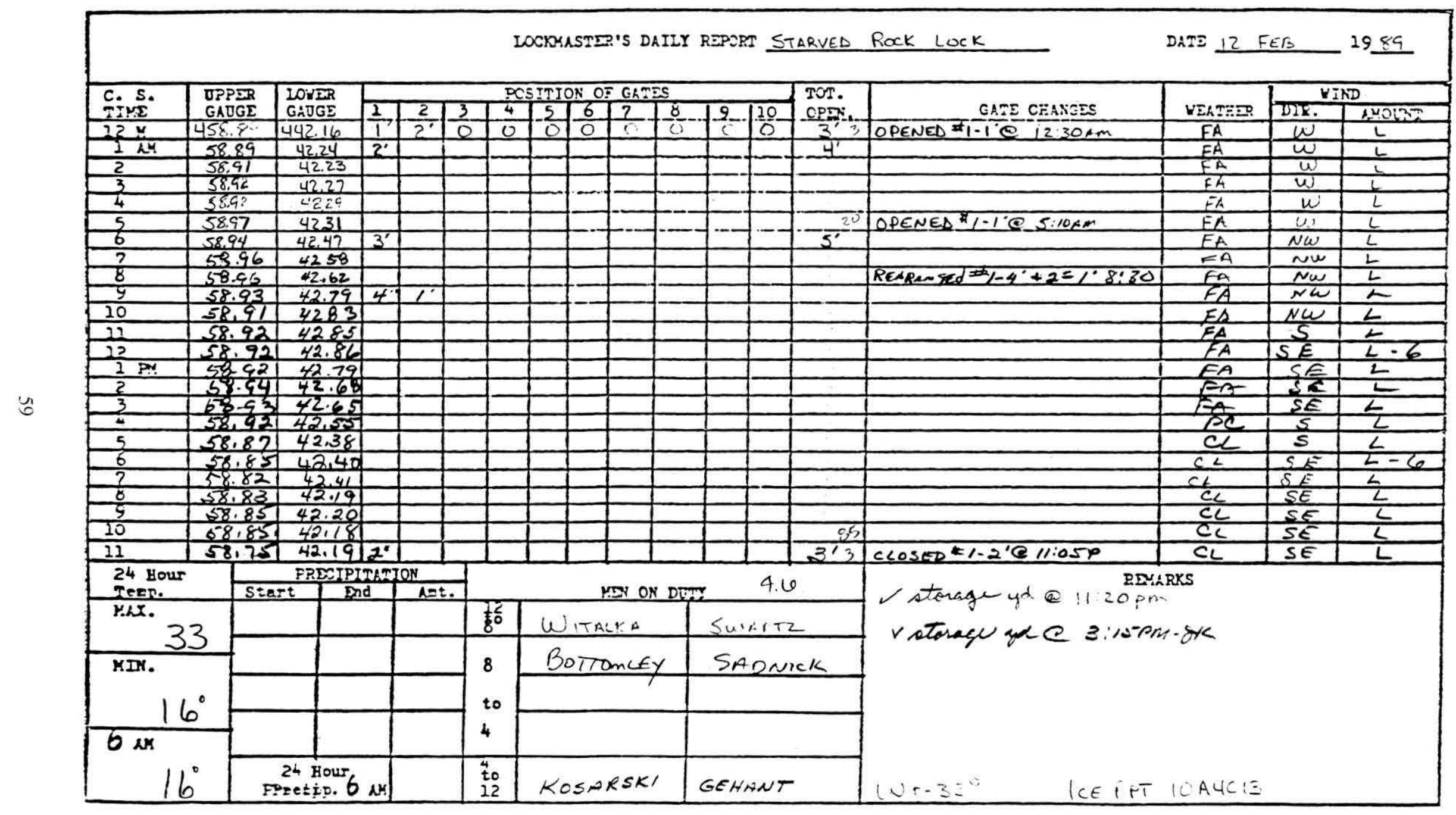




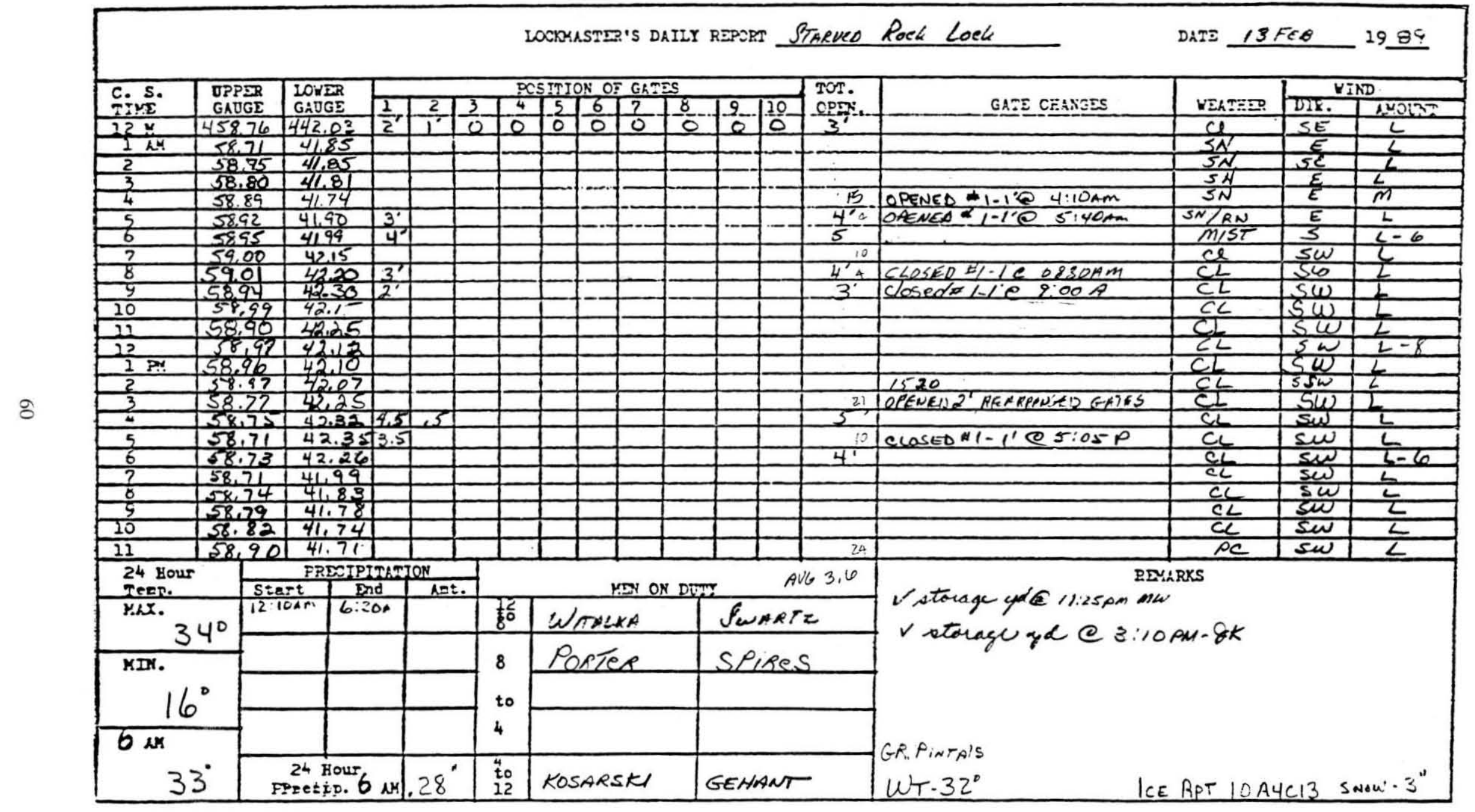




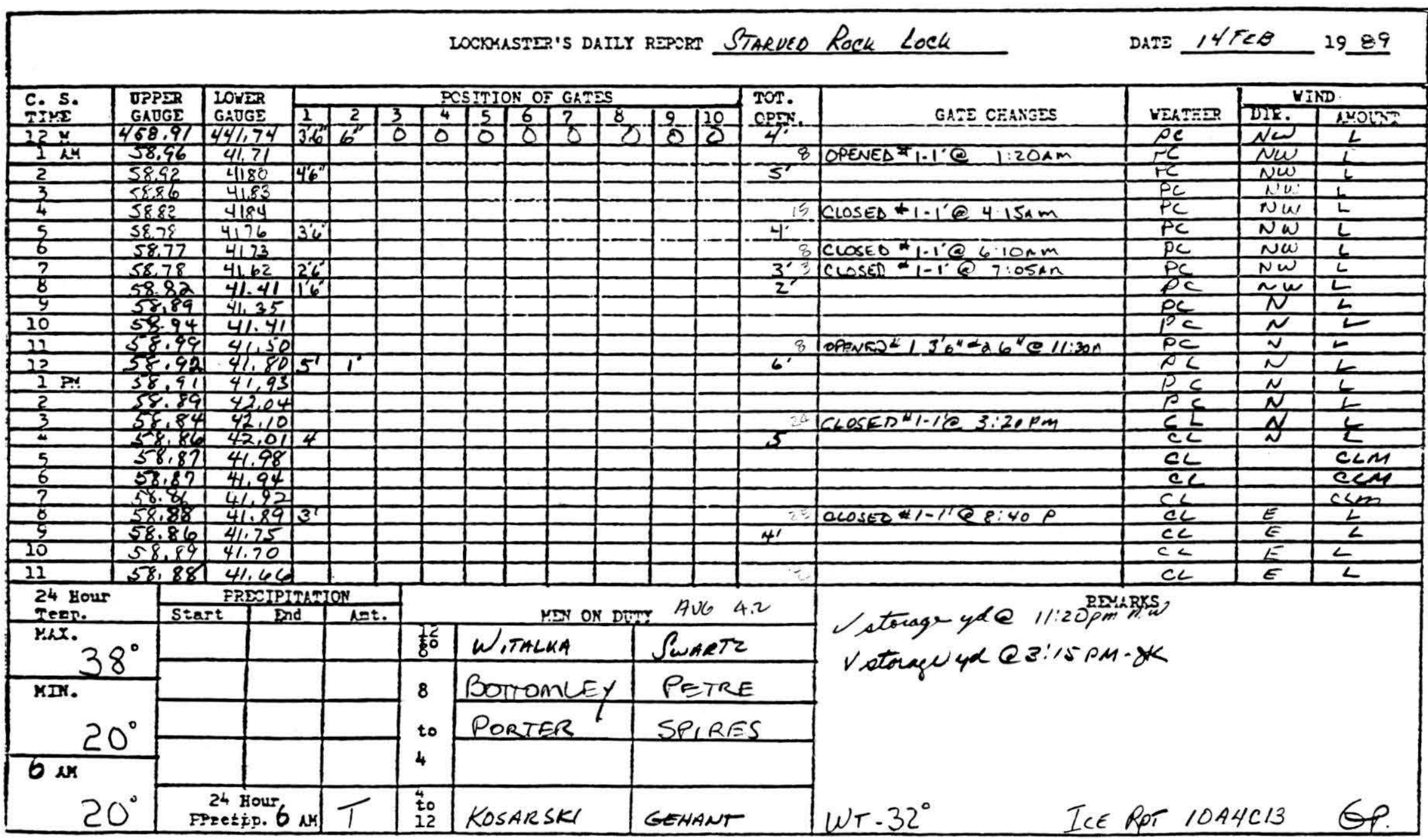




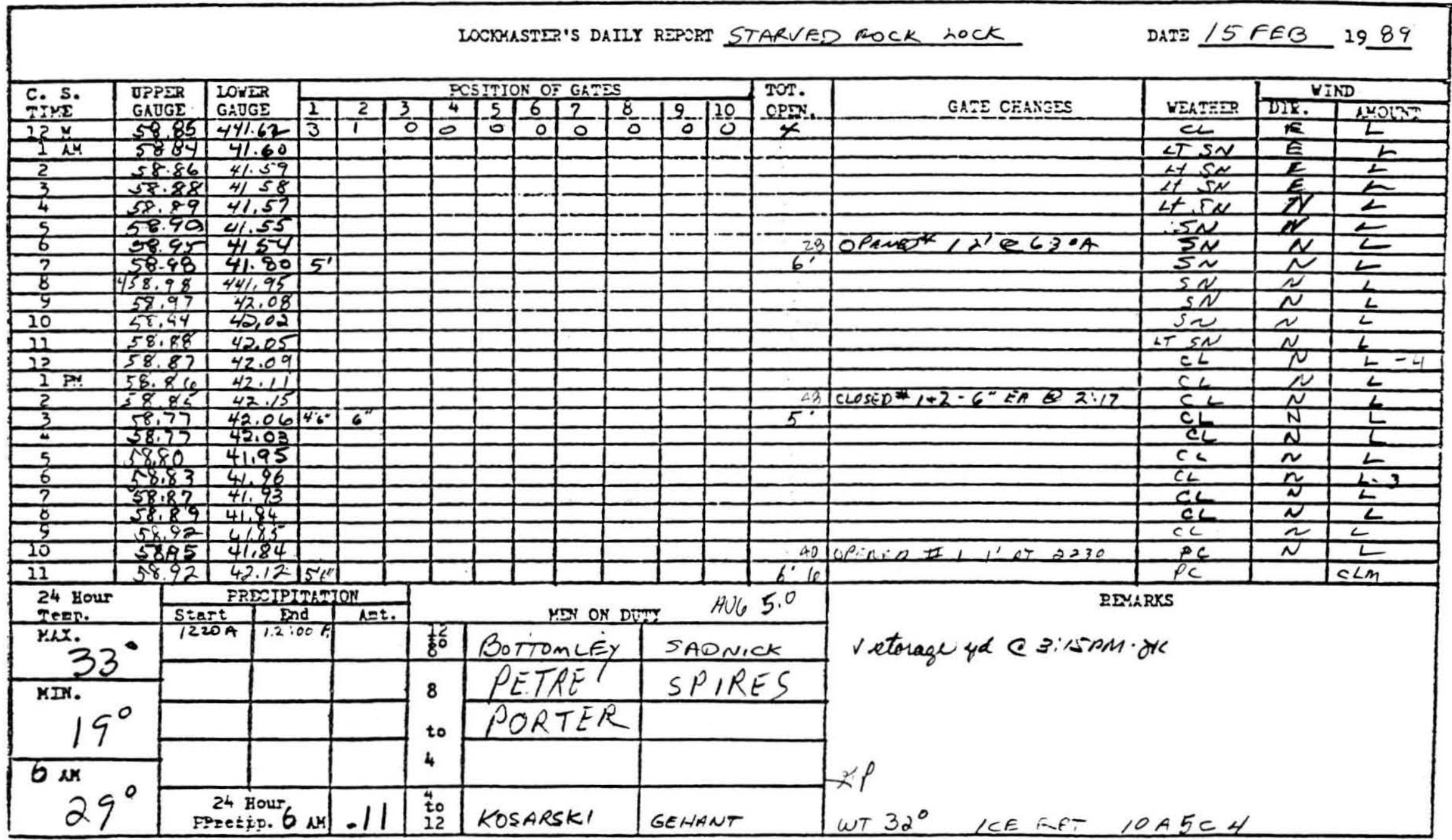




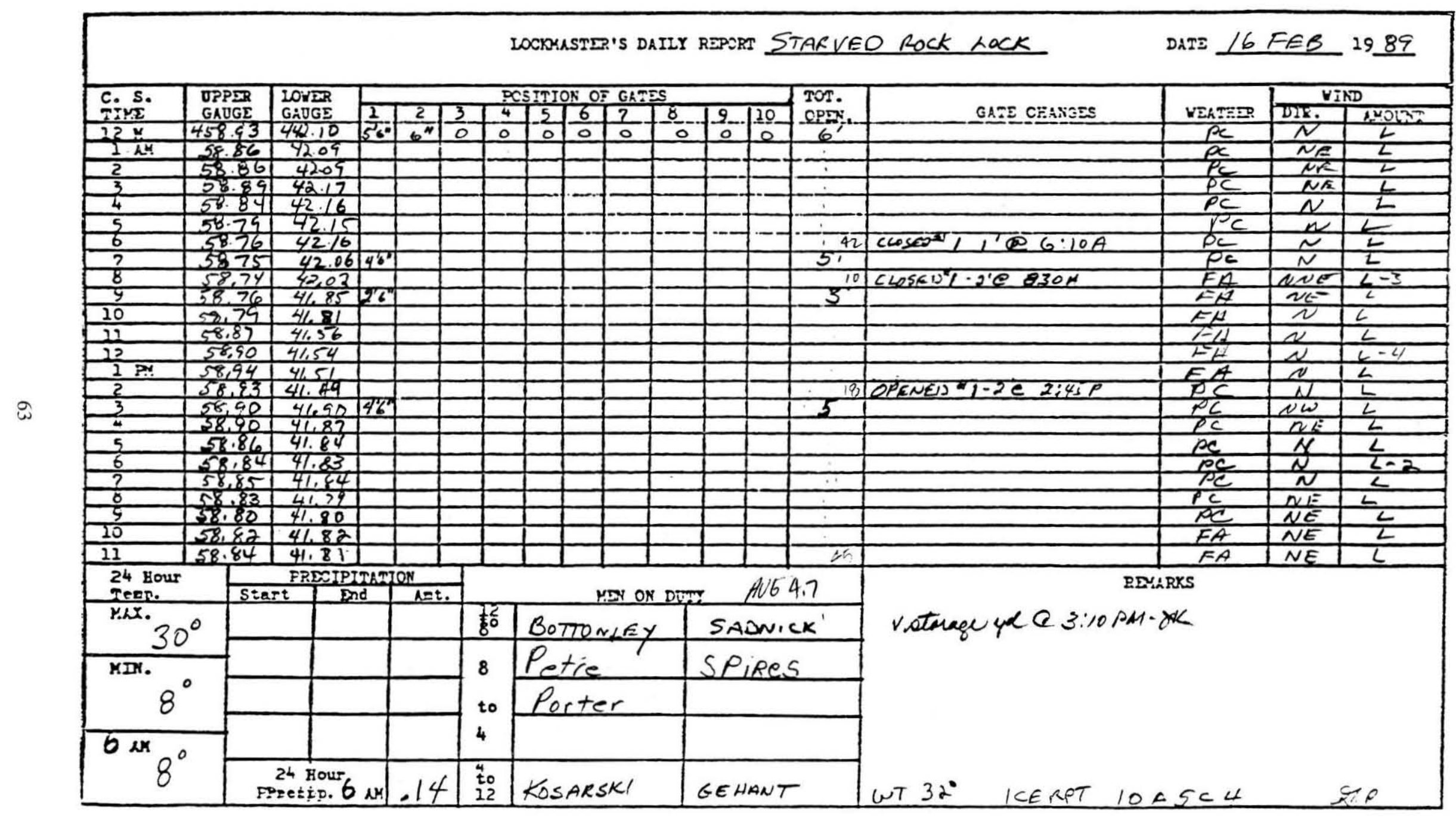




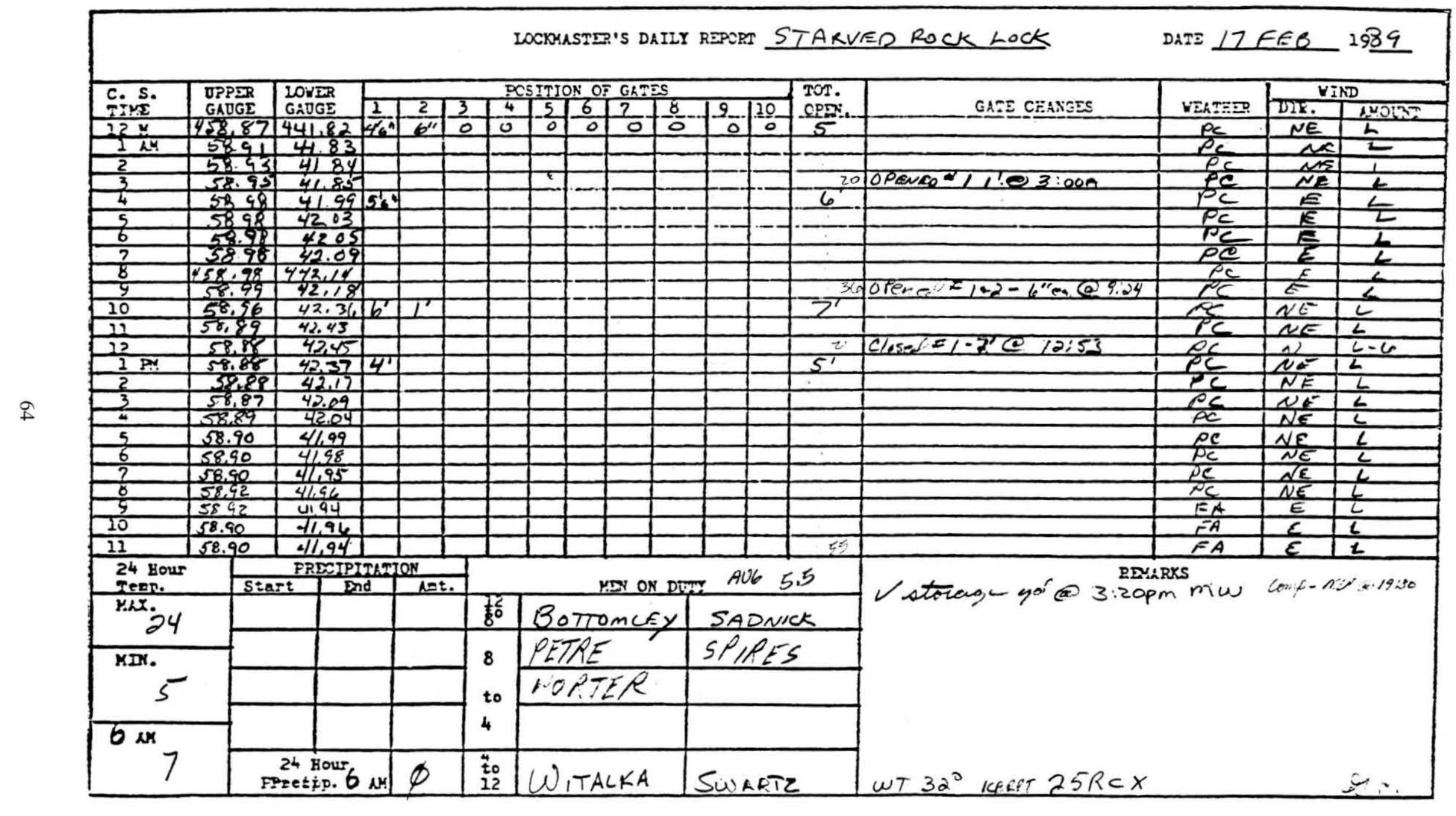




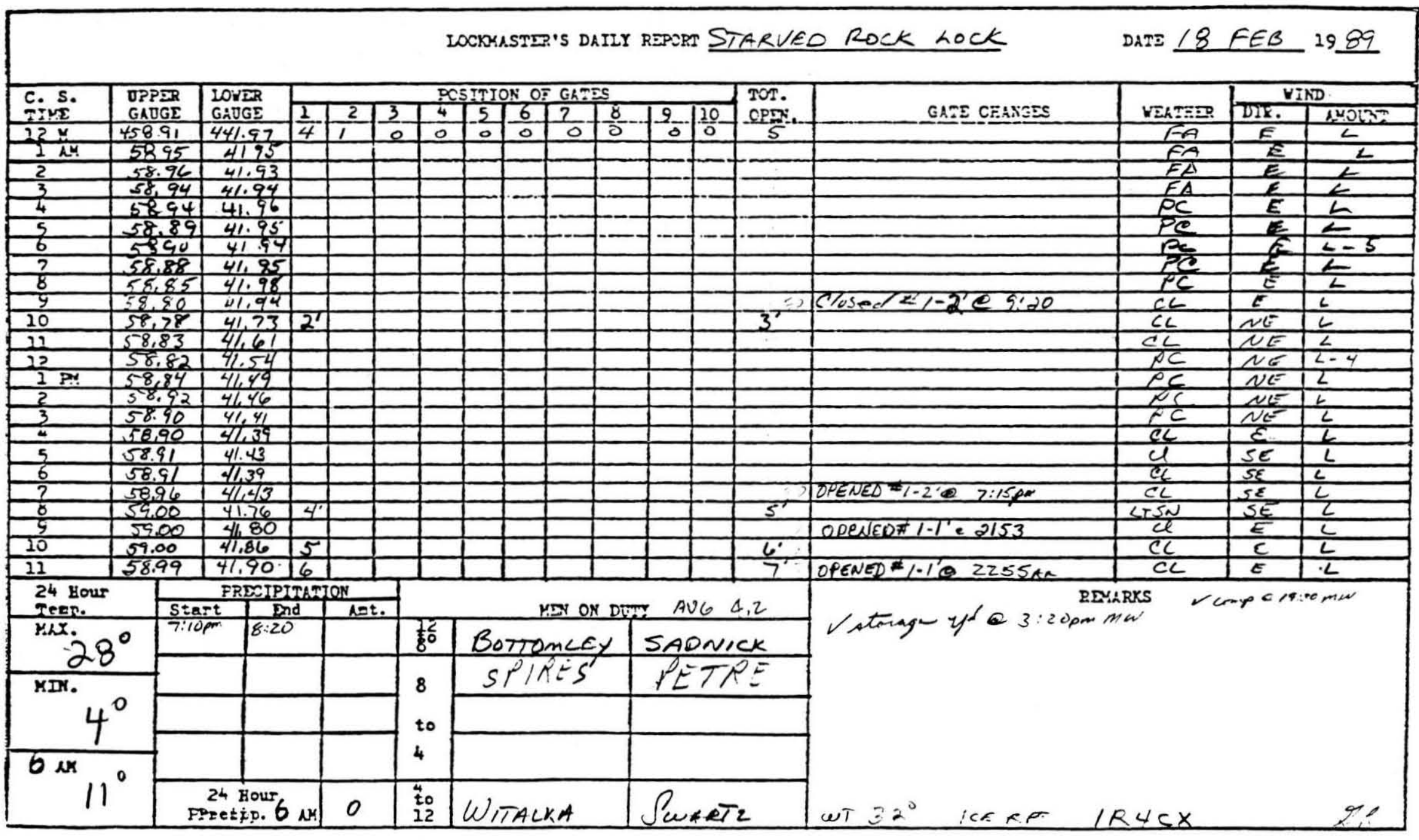




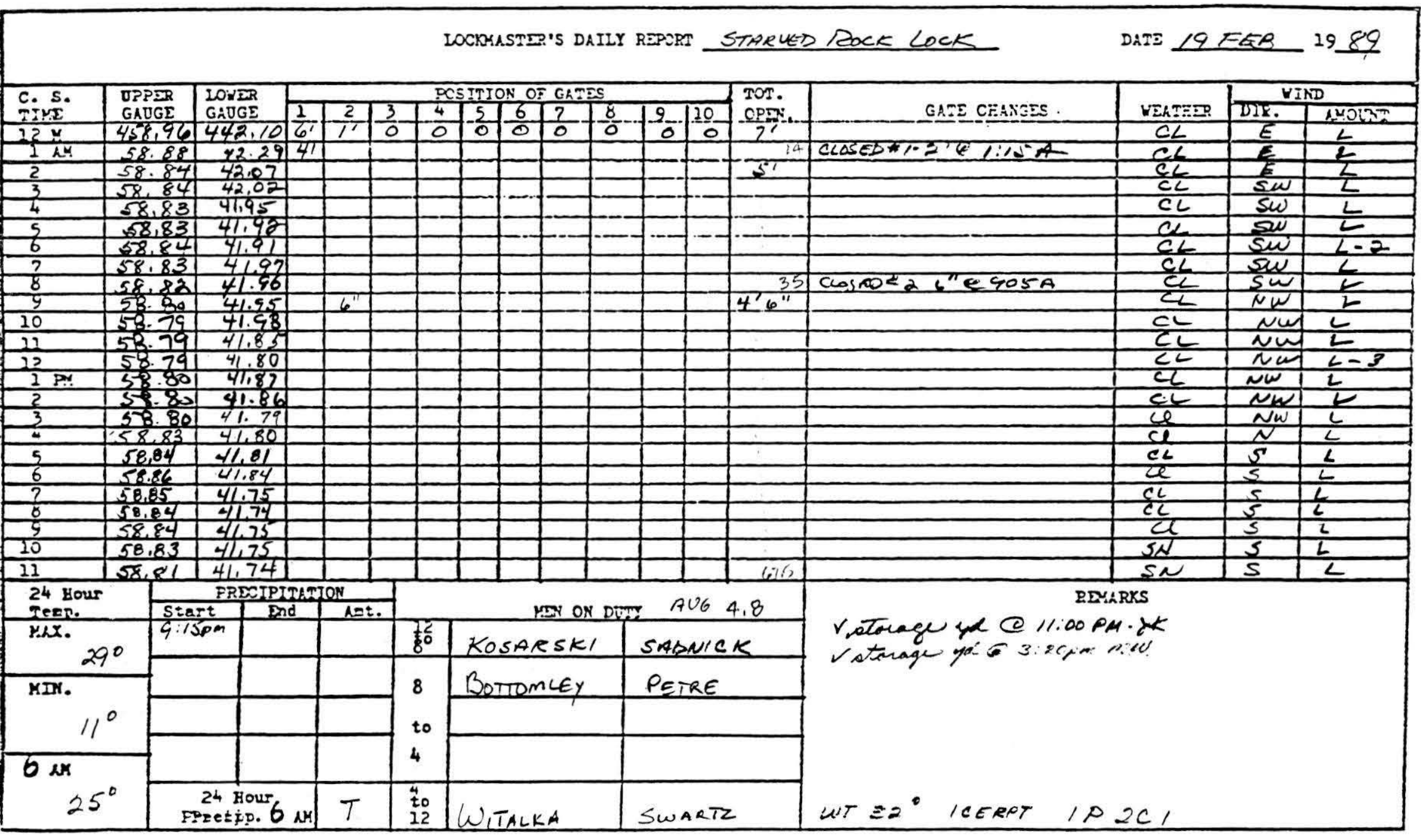




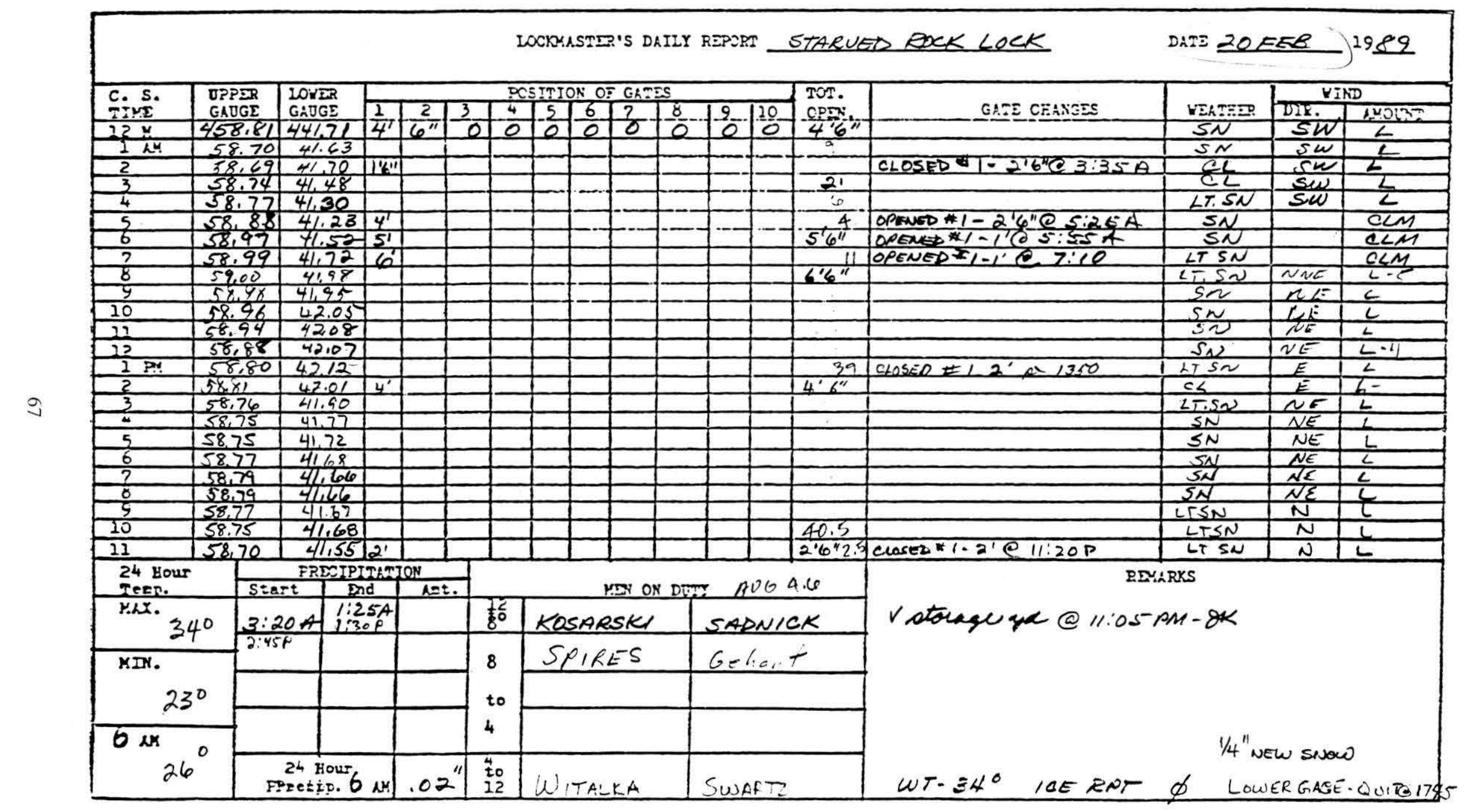




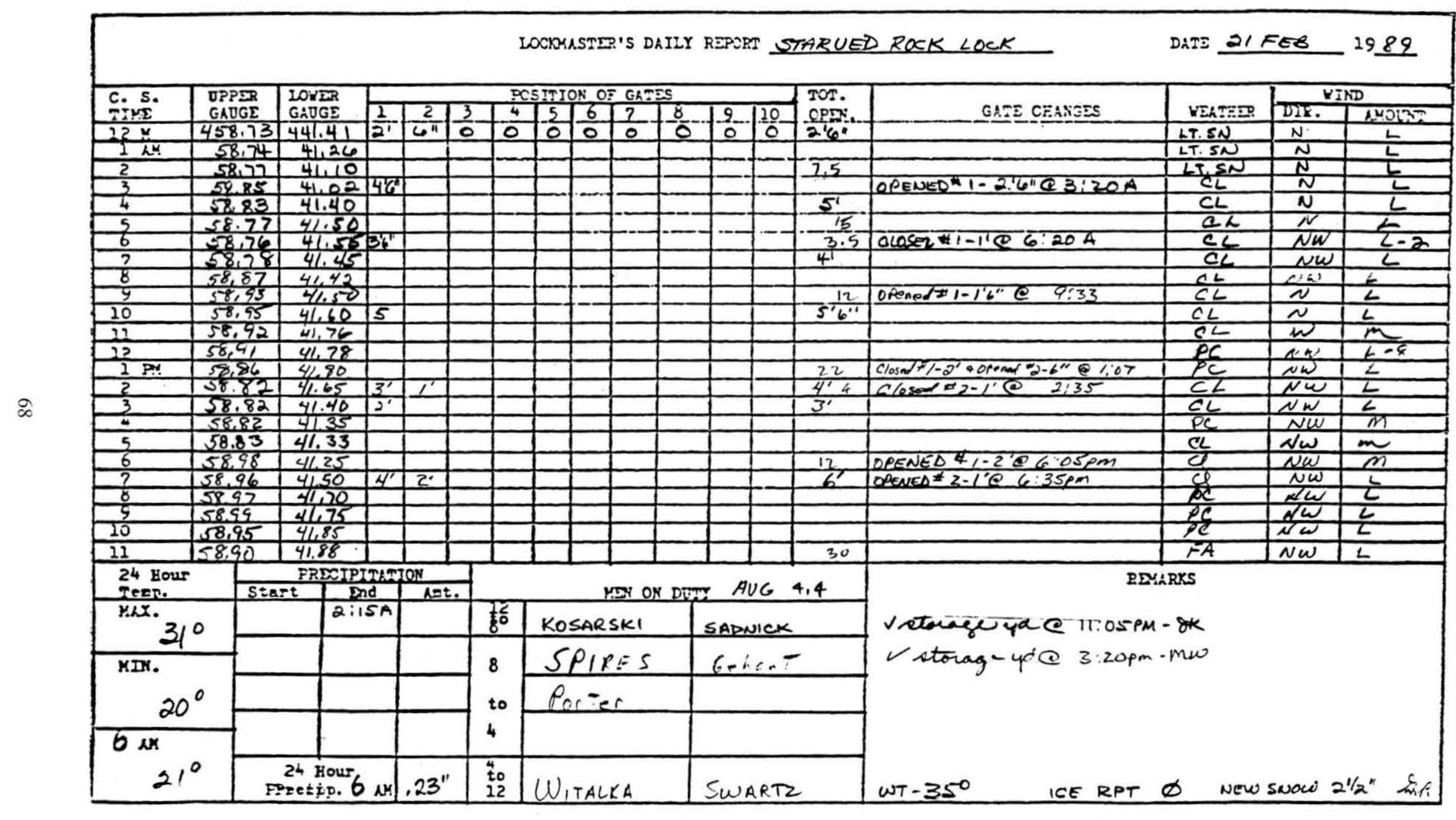




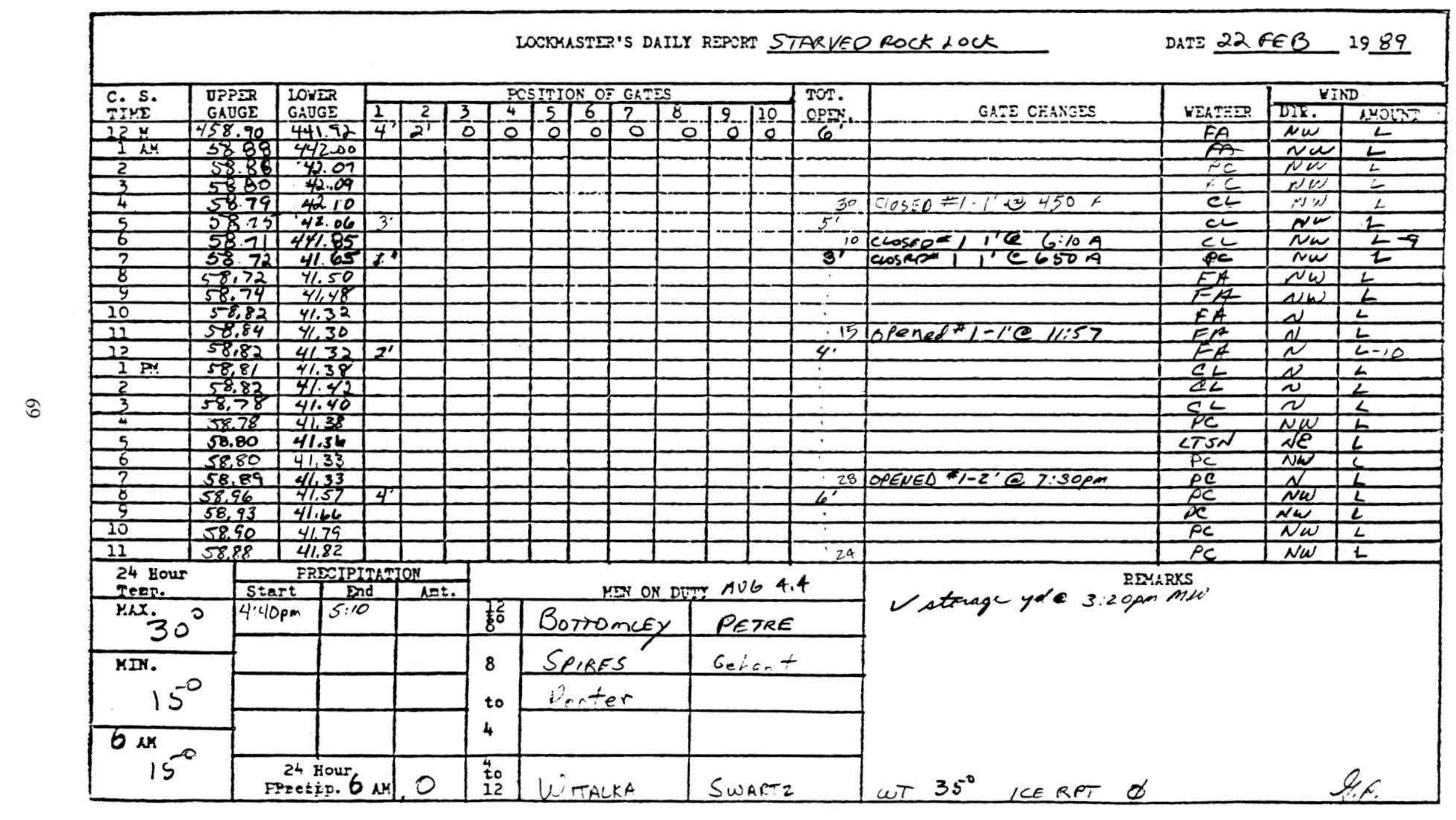




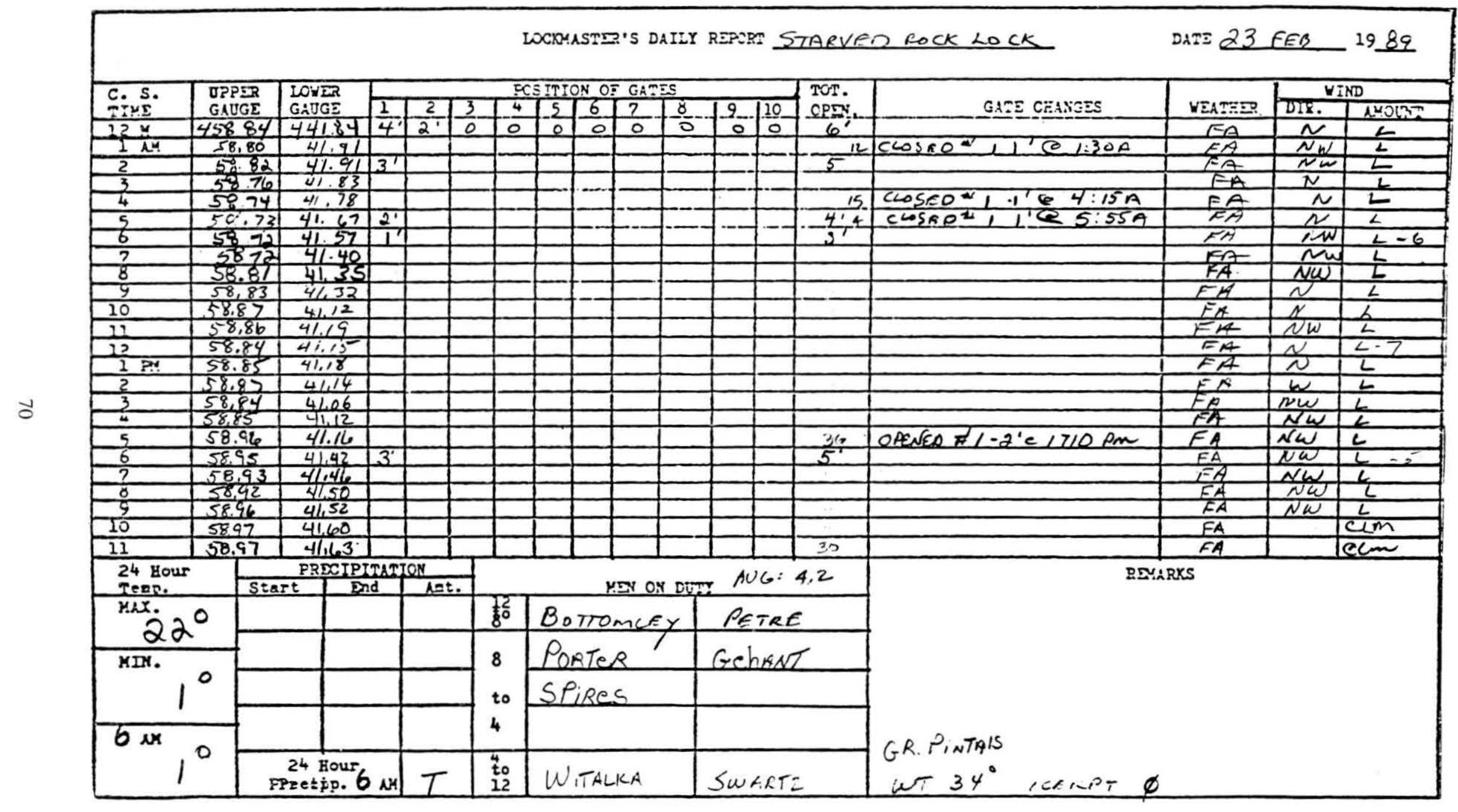




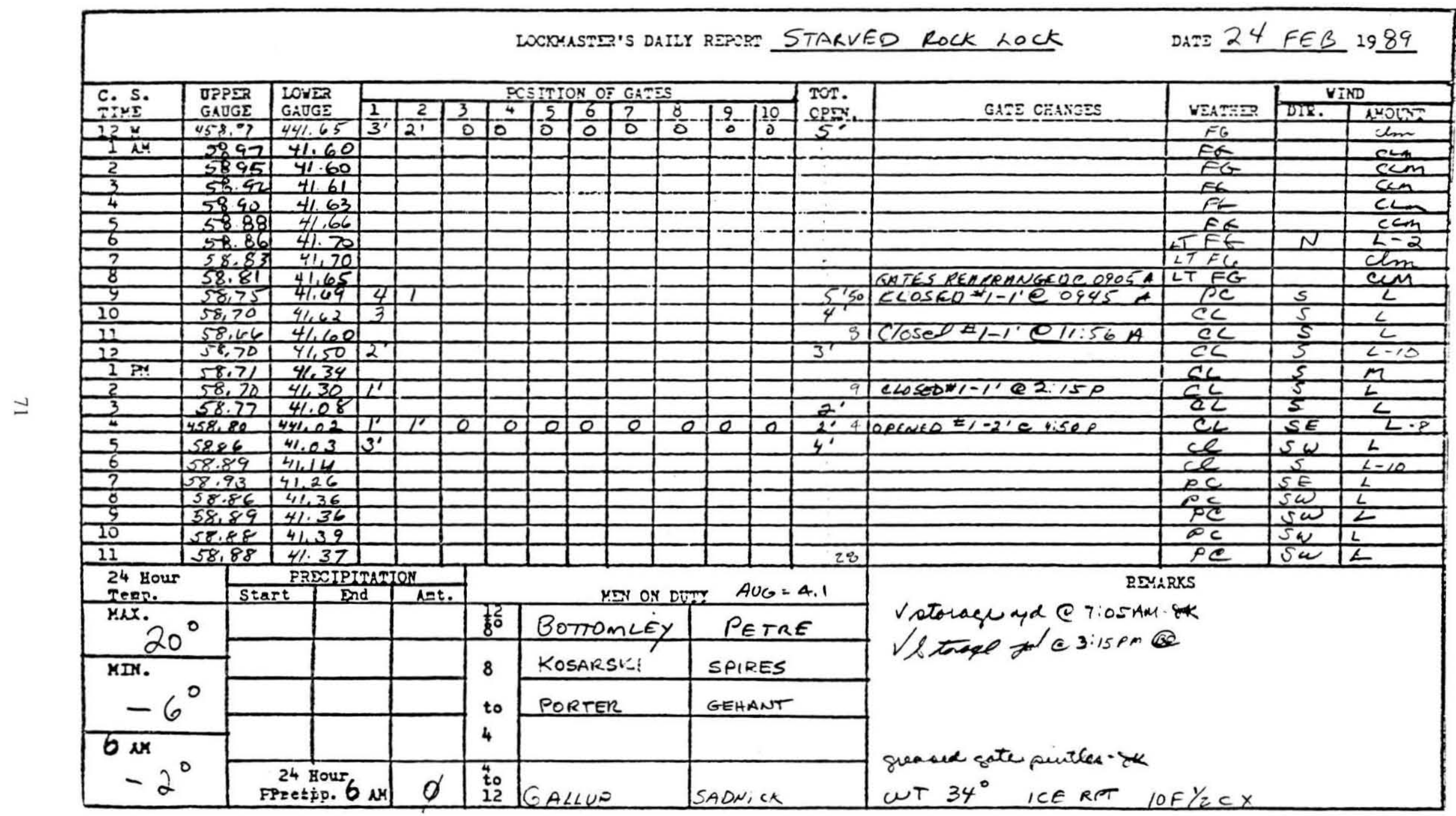




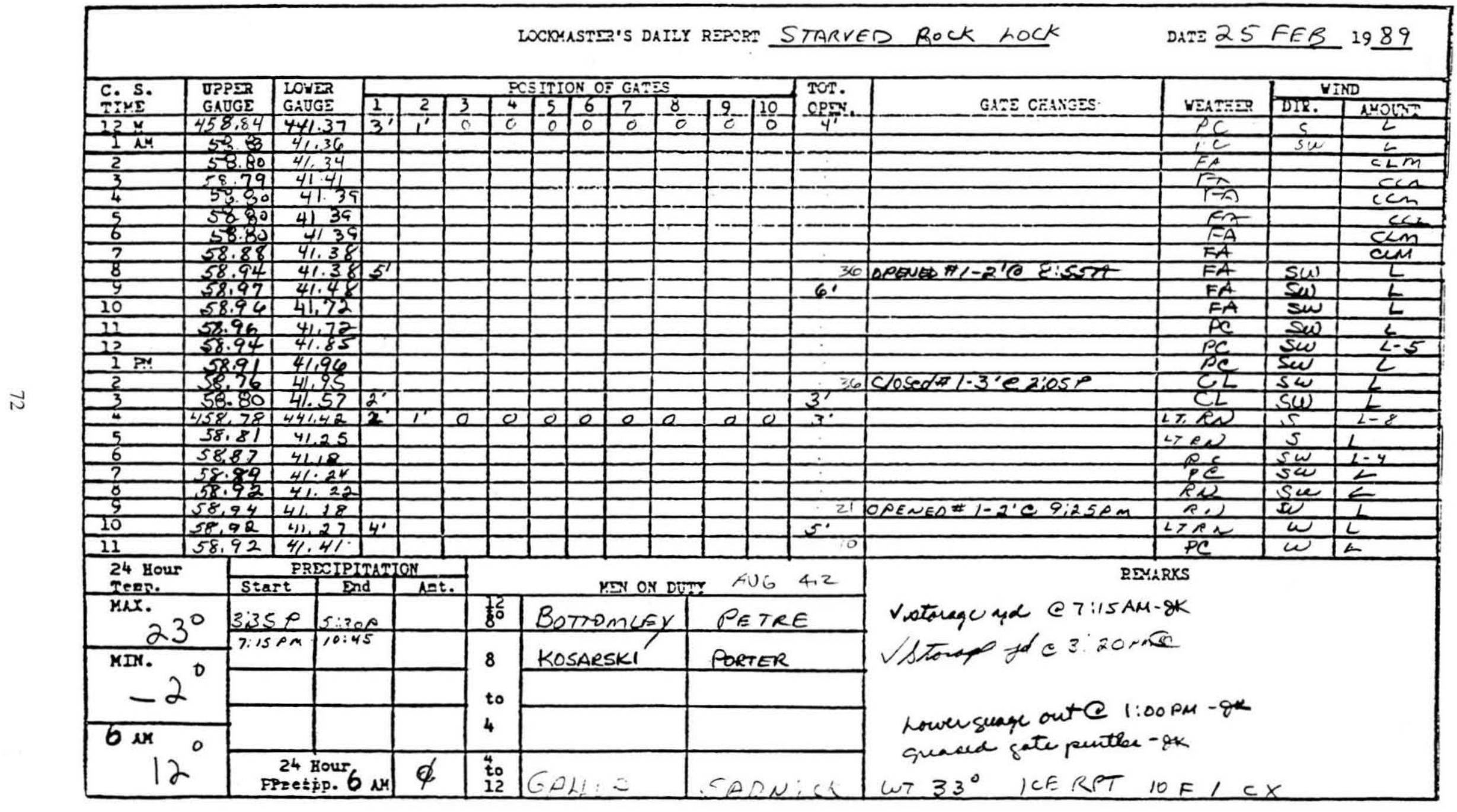




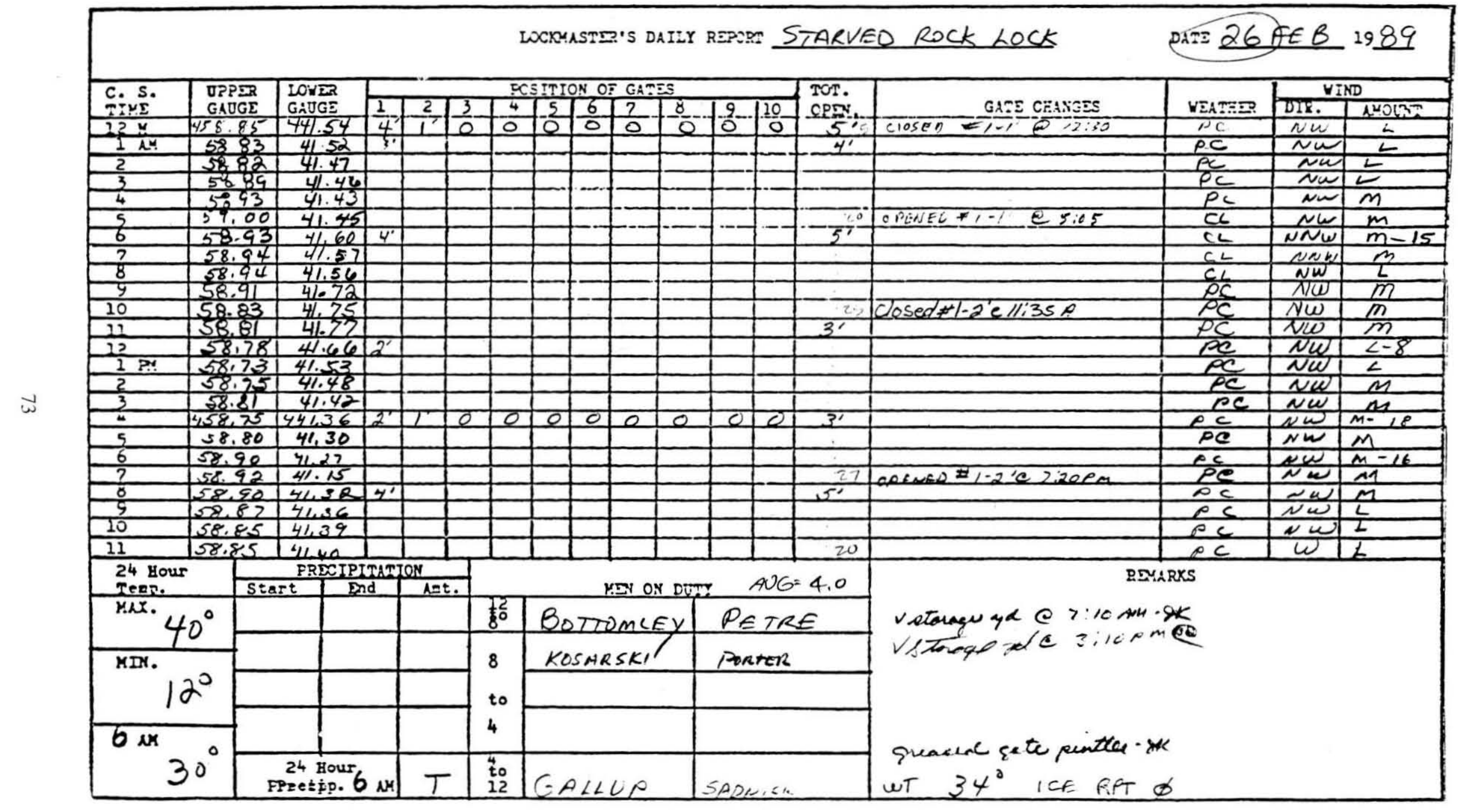




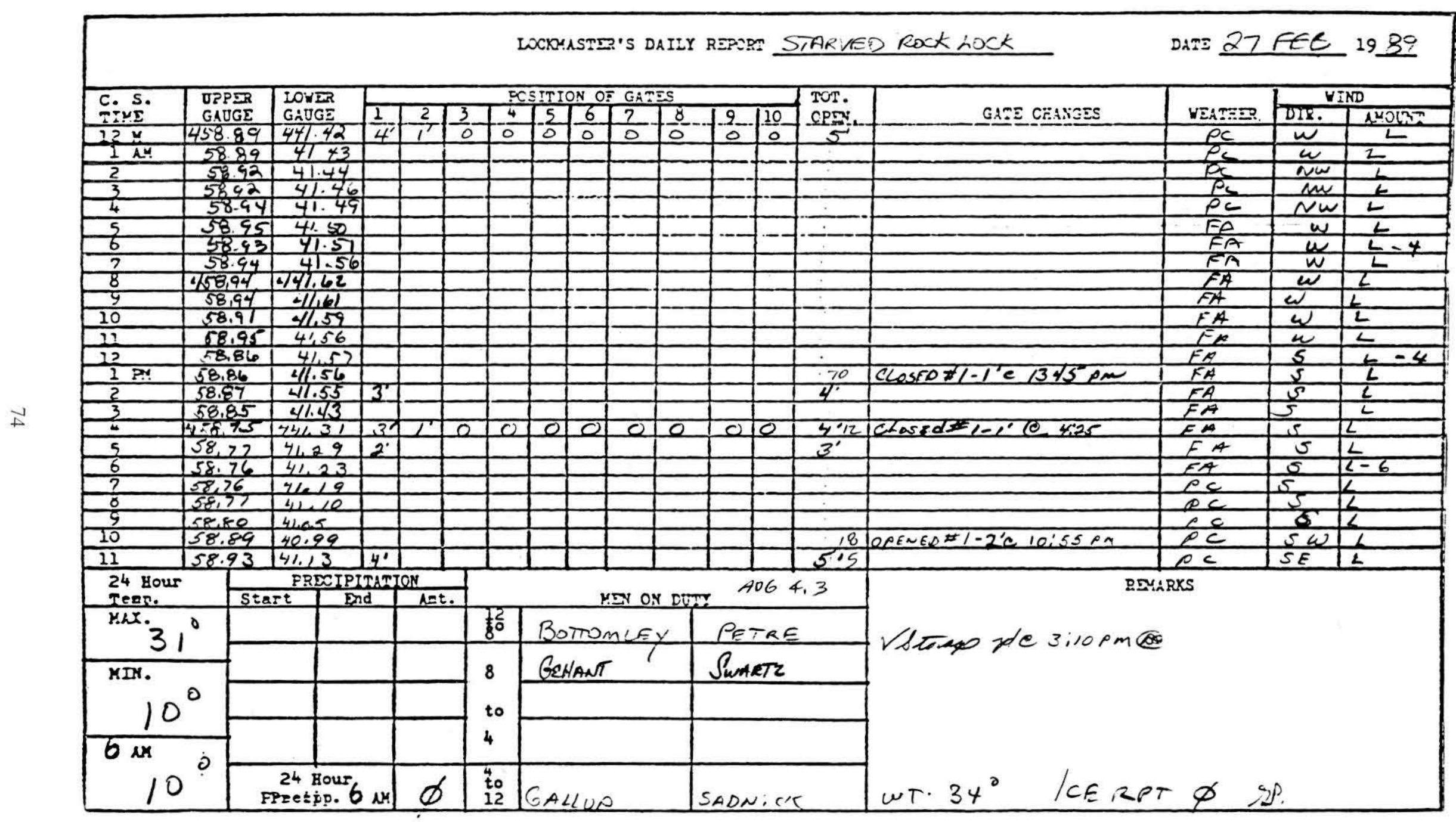




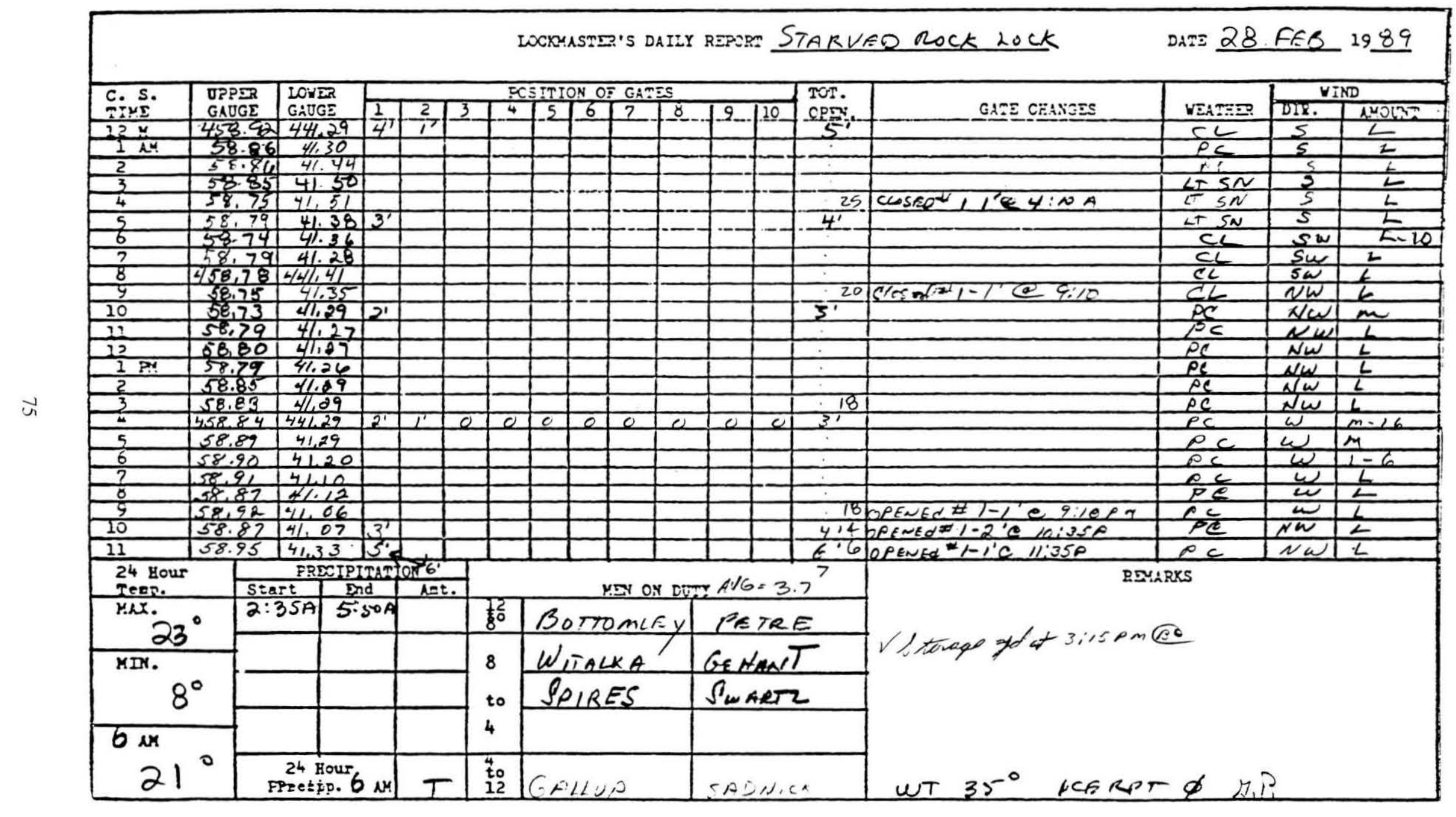


Public reporting burden for this collection of information is estimated to average 1 hour per response, including the time for reviewing instructions, searching existing data sources, gathering an maintaining the data needed, and completing and reviewing the collection of information. Send comments regarding this burden estimate or any other aspect of this collection of information, including suggestion for reducing this burden, to Washington Headquarters Services, Directorate for Information Operations and Reports, 1215 Jefferson Davis Highway, Suite 1204, Arlington, VA 22202-4302, and to the Office of Management and Budget, Paperwork Reduction Project (0704-0188), Washington, DC 20503.

\begin{tabular}{|l|l|l|}
\hline 1. AGENCY USE ONLY (Leave blank) & 2. REPORT DATE & 3. REPCRT TYPE AND DATES COVERED
\end{tabular}

November 1990

4. TITLE AND SUBTITLE

5. FUNDING NUMBERS

Modeling Ice Passage Through Submergible and

Non-submergible Tainter Gates

6. AUTHORS

Gordon Gooch, John Rand, Ben Hanamoto and Jon Zufelt

7. PERFORMING ORGANIZATION NAME(S) AND ADDRESS(ES)

U.S. Army Cold Regions Research and Engineering Laboratory

72 Lyme Road

Hanover, New Hampshire 03755-1290

8. PERFORMING ORGANIZATION REPORT NUMBER

Special Report 90-39

9. SPONSORING/MONITORING AGENCY NAME(S) AND ADDRESS(ES)

10. SPONSORING/MONITORING AGENCY REPORT NUMBER

U.S. Army Engineer District, Rock Island

Rock Island, Illinois 61201

11. SUPPLEMENTARY NOTES

12a. DISTRIBUTION/AVAILABILITY STATEMENT

12b. DISTRIBUTION CODE

Approved for public release; distribution is unlimited.

Available from NTIS, Springfield, Virginia 22161.

13. ABSTRACT (Maximum 200 words)

In the colder regions of the U.S., ice accumulation in the approach area of navigation locks has been a constant problem. This ice is often pushed into the lock ahead of a towboat, sometimes requiring a separate lock cycle. This reduces the efficiency of the lock and slows down ship traffic. By modeling this problem and testing the solution to it, the research team has been able to conclusively show that submergible tainter gates located near the approach will solve the above-mentioned ice problems.

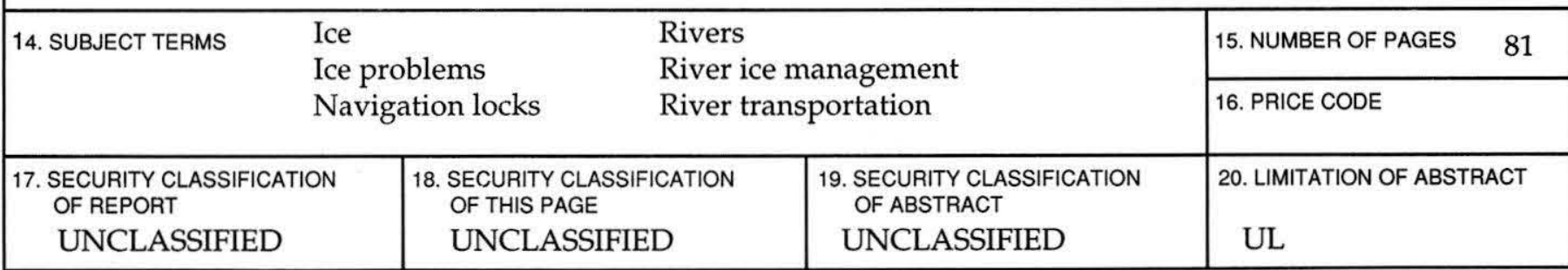

